\title{
On the embankment dam
}

\author{
A. D. M. PENMAN*
}

\begin{abstract}
'There is a mathematical theory of the combined action of friction and adhesion in earth: but for want of experimental data its practical utility is doubtful'-Rankine
\end{abstract}

The significance of the embankment dam stems from its importance to mankind in providing one of the cheap. est means for storing large volumes of water. Historically this was required for irrigation, but it is also a necessity for hydro-power and supply for industrial and domestic use. The embankment dam was the first type of dam built by man: it is the most numerous type; it is the type most often chosen for a new dam and forms the world's highest dam. It was rivalled by various forms of concrete dam, but developments since the 1930s in geotechnical science, understanding of behaviour through instrumentation and improvement of earth-moving machinery has made it the foremost type of dam throughout the world. Improved methods of stability analysis, utilizing the concept of effective stresses and measured pore pressures, enable safe slopes to be constructed. Weaknesses due to slickensides and/or the effects of failure developing progressively along a potential slip surface clearly must be given due consideration. The simple concept of expressing soil strength, whether peak or residual, in terms of $c^{\prime}$ and $\varphi^{\prime}$ is beginning to be replaced by the concept of a curved failure envelope and analytical methods are available for stability analysis. Despite these advances some slips still occur. Three cases are considered. It may be preferable to design for acceptable movement rather than simply to provide a factor of safety against unacceptable slip failure. Analytical methods utilizing finite element techniques have enabled predictions to be made from deformation parameters. To assess these methods, accurate measurements of movements are required. Movements that occur during temporary cessation of construction can give valuable indications of strains developing within the dam that may cause undesirable reduction of stress or onset of progressive failure. Precise measurements of horizontal movements, even without instruments to measure inside the fill, can reveal a change to unacceptable rates of movement. Arching action, not only across a narrow core, but across a dam from upstream to downstream and between abutments may result in undesirable reduction of total stresses, leading to hydraulic fracture. Failure due to erosion and piping is most dangerous because it can occur while the reservoir is full. Improved design of filters may limit erosion, but it may be better to ensure also that total stresses across any potential plane of fracture through the waterprool system are adequate to prevent hydraulic fracture. Cases of hydraulic fracture and examples of wet seams are discussed. It is probable that many cases of leakage

* Geotechnical Engineering Consultant, Harpenden. originate in hydraulic fracture. The subsequent degree of erosion under conditions of zero effective stress may be dependent on many factors that require detailed research study.

L'importance du barrage en terre pour l'humanité provicnt de ce qu'il représente un des moyens les moins coûteux pour amasser de grands volumes d'eau. A une époque reculée de tels barrages servaient pour l'irrigation, mais ils restent encore nécessaires pour la puissance hydro-électrique et pour les besoins industriels et domestiques. Le barrage en terre a eté le premier barrage à être construit par l'homme; il constitue toujours le type de barrage le plus nombreux. On le choisit le plus souvent pour un nouveau barrage et ce genre de barrage a été utilisé pour les plus grandes hauteurs. Différentes formes de barrage en béton lui faisait concurrence, mais le barrage en terre reste encore le type le plus important dans tous les pays, grâce à l'évolution des sciences géotechniques depuis les années 1930, à la compréhension approfondie du comportement des barrages réalisée grâce à l'instrumentation et aux perfectionnements effectués dans les machines employées pour les travaux de terrassement. Il est possible de réaliser des pentes stables à l'aide des méthodes améliorées pour analyser la stabilité, basées sur le concept de contraintes effectives et de pressions interstiticlles mesurécs. II faut bien entendu tenir compte des faiblesses due aux surfaces de glissement et/ou des effets des ruptures qui peuvent se produire de façon progressive le long d'une surface miroir potentielle. Le concept simple d'exprimer la résistance maximale ou résiduelle du sol en fonction de la cohé sion effective $c^{\prime}$ et de l'angle de frottement effectif $\varphi^{\prime}$ commence à être remplacé par celui de l'cnvelope de rupture non rectiligne, tandis que des méthodes analytiques sont disponibles pour évaluer la stabilité. Malgré tous ces progrès il arrive que des glissements se produisent encore. Trois cas sont décrits en détail. Peutêtre est il préférable de calculer le barrage en fonction d'un mouvement admissible plutôt que de fournir seulement un cocfficient de sćcurité contre la rupture par glissement. On a pu faire des prédictions sur la base des paramètres de déformation à l'aide de méthodes analytiques utilisant des techniques d'éléments finis. Des mesures précises des mouvements sont nécessaires pour évaluer ces méthodes. Des mouvements qui ont lieu à l'occasion des pauses pendant les travaux de construction peuvent donner des indications précieuses concernant les déformations qui se produisent dans le barrage et qui peuvent causer une réduction inadmissible de 
contrainte ou le commencement de rupture progressive. Des mesures précises des mouvements horizontaux, effectuées même en l'absence d'instruments à l'interieur du remblai, peuvent révéler un changement vers des vitesses inadmissibles de mouvement. Une réduction inadmissible des contraintes totales, entrainant une rupture hydraulique, peut provenir d'un effet de voũte non seulement en travers d'un noyau étroit, mais en travers d'un barrage entre ses côtés en amont et en aval et aussi entre des dispositifs de butée. La rupture due à l'érosion et au renard est très dangereuse, parce qu'elle peut se produire lorsque le bassin de retenue est rempli d'eau. L'érosion peut être limitée par des filtres de construction perfectionnée, mais peut-être vaudra-t-il mieux aussi de prendre des mesures pour que les contraintes totales en travers tout plan de rupture potentiel dans le système imperméable soient suffisantes pour empêcher la rupture hydraulique. Des cas de rupture hydrauliques et des exemples de lignes de séparation humides sont discutés. Il est probable que la rupture hydraulique est à l'origine de beaucoup de cas de fuites. L'érosion qui s'ensuit dans des conditions de contrainte effective nulle peut dépendre de beaucoup de facteurs qui exigent une étude approfondie.

\section{SIGNIFICANCE OF THE EMBANKMENT DAM}

The benefit of dams to mankind is undoubted. Their earliest role in providing storage for irrigation water formed a major contribution to the development of our civilization. The oldest dam in the world (Kerisel (1985), quoting Helms), dating from around $4000 \mathrm{BC}$, was built of earth with a masonry facing, at Jawa in Jordan. In India there was a tradition of dam building that at one time was considered as one of the seven meritorious acts which a man ought to perform during his lifetime (Rao, 1951). During the period of British tenure, many dams were constructed by traditional methods and they were accepted as a means of famine relief giving cmployment to thousands. The completed schemes, in ensuring crop production, not only paid, but brought happiness and contentment to the people (Buckley, 1898). Today, vast areas of land throughout the world rely for their productivity on irrigation, e.g. southern California fed from the reservoirs at Trinity $(142 \mathrm{~m})$, Oroville $(230 \mathrm{~m})$ and other large embankment dams.

In Britain, the Industrial Revolution required water for transport, industrial processes and the growing cities. In the 18th century, dams were built to store water for canals; during the 19th century, the majority were for water supply; early in the 20th century, dams specifically for hydropower were constructed in Scotland and Wales to provide electricity for aluminium smelting. Ingots from arc furnaces were produced in June 1896 (Hamilton, 1986) with power from Foyers Dam that had just been completed. It is claimed that Cragside, the home of Lord Armstrong in North- umberland, was the first house to be lit by electricity derived from water power: by arc lamps in 1878 and Swan's incandescent lamps two years later. A small embankment dam that is still operational had been built by estate workers under Armstrong's direction to impound water for a Thomson vortex turbine.

The prospect of almost limitless renewable energy offered by hydro-power excited the world. The International Union of Producers and Distributors of Electrical Energy, realizing the need for development of the specialized knowledge of dam building, conceived the International Commission on Large Dams (ICOLD) in 1928. This new body became a Commission of the World Power Conference in 1930 and has continued to attract new member countries: currently the membership of ICOLD comprises 77 countries. The interchange of experience and dissemination of research findings has made this body of inestimable value: congress transactions and the publications of technical committees form milestones in the development of the subject.

\section{World register}

To assess the number, type and size of dams and reservoirs, ICOLD took on the daunting task of compiling a world register: the 1985 edition contains information from 116 countries and has been used to construct Fig. 1. In general, to be eligible for entry, a dam's height must exceed $15 \mathrm{~m}$, but for the four countries (China, Japan, India, USA) with more than 1000 dams, only those exceeding $30 \mathrm{~m}$ height have been included. Thus the register excludes large numbers of small dams, many of which are of the embankment type, e.g. Britain is shown to have 411 embankment dams and 125 of other types of dam, whereas it has been estimated that there are more than 2000 subject to the Reservoirs (Safety Provisions) Act of 1930 in the country. An exact number will not be known until implementation of the 1975 Reservoirs Act produces the required national register. The height of dams given by this latest edition of the world register is from lowest foundation rather than from stream bed level.

Accepting these limitations, Fig. 1 shows the increase in the number of large embankment dams during the period 1800-1985. Since 1955 , the number has been increasing at an almost constant rate of 200 per year. Clearly the increase is a response to the accelerating increase of world population. The height of embankment dams is of considerable geotechnical interest in view of the stresses and water pressures developed: the world's highest exceeded $100 \mathrm{~m}$ in $1926,200 \mathrm{~m}$ in 1968 and $300 \mathrm{~m}$ in 1980. 


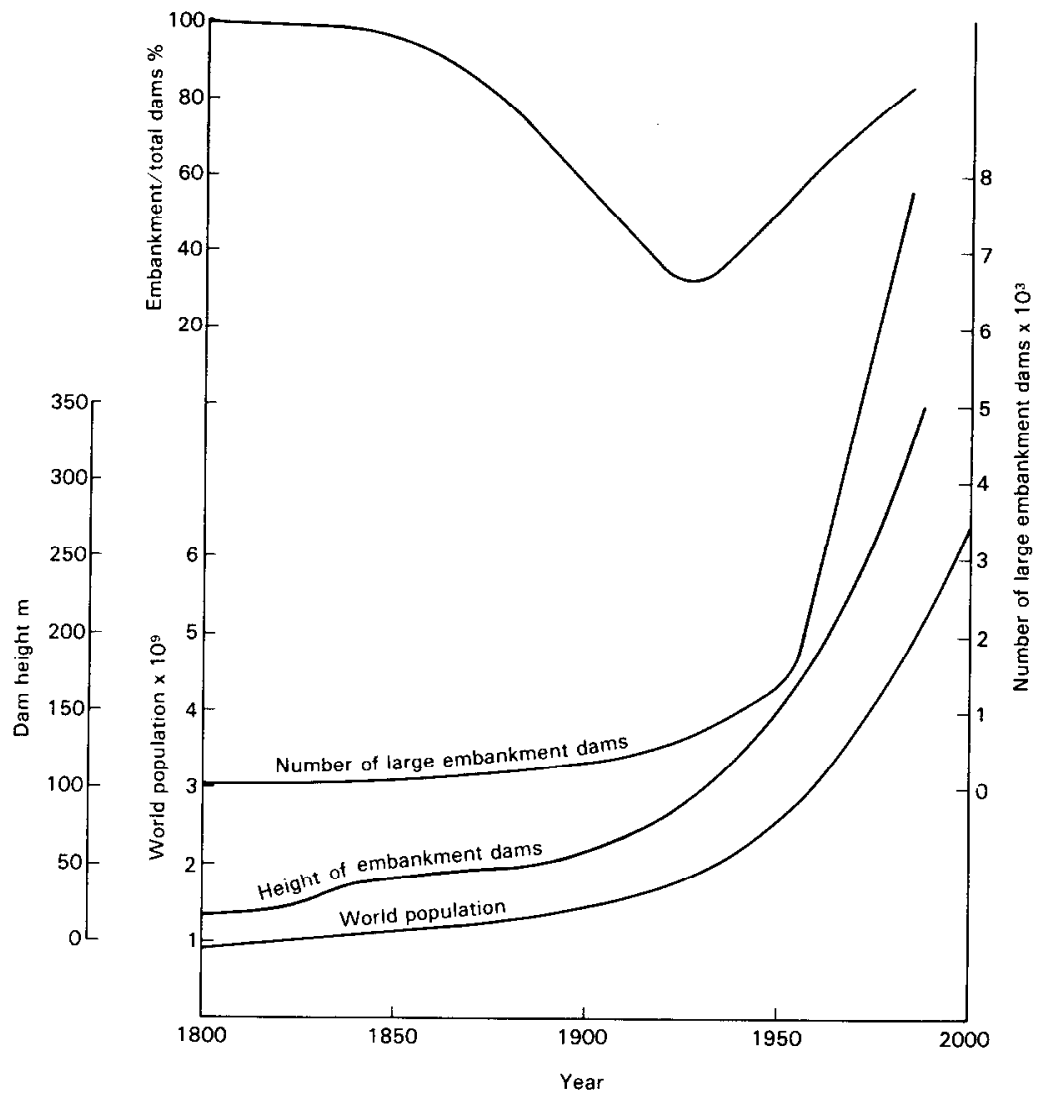

Fig. 1. Embankment dam statistics 1800-1985

Currently the world's highest dam is the Russian embankment dam Nurek, $300 \mathrm{~m}$. For about 18 years, before it reached full height, the world's highest dam was the concrete gravity Grand Dixence (285 $\mathrm{m}$ ) in Switzerland, completed in 1962. During that period, first Oroville $(230 \mathrm{~m}$, USA, 1968) and then Mica (242 m, Canada, 1972) were the highest embankment dams.

Mica was exceeded by Chicoasen, $261 \mathrm{~m}$, completed in Mexico in 1980. Two projected embankment dams in India are Tehri, $261 \mathrm{~m}$, and Kishau, $253 \mathrm{~m}$, both in Uttar Pradesh and expected to be completed during 1985-90. Rogun, the $335 \mathrm{~m}$ embankment dam in Russia will be the world's highest dam when it is completed.

Almost all the world's dams were of the embankment type before 1800 . During the 19th century, concrete technology and methods of structural analysis evolved. Combined with the fact that there were many sites available with sound rock foundations at shallow depths, this created an increasing interest in concrete dams. The effect was to reduce the ratio of embankment to total number of dams built, from the approx- imately $100 \%$ value that had previously existed. This ratio for dams built in a five-year period (Fig. 1) shows that by the turn of the century there were more large concrete than large embankment dams being built. The ratio reached its lowest value of $33 \%$ in the late $1920 \mathrm{~s}$, but has now recovered and of all large dams built recently more than $80 \%$ are of the embankment type.

\section{Improved standing}

The embankment dam represents an almost purely geotechnical problem. Much of the recovery can be attributed to improvements in design methods due to developments in soil mechanics since publication of Erdbaumechanik in 1925 and the introduction of instrumentation to reveal dam behaviour. These have enabled a wider range of local soils and rocks to be used, heights to be vastly increased and very difficult foundations to be accepted.

The introduction of the internal combustion engine to power earth-moving machinery has also played a major role. In addition to providing large concentrations of power for excavating 
strong soils and rock and compacting them effectively, the cost has always been lower than muscle power. Construction in India (Strange, 1898) could involve 20000 people excavating soil with pickaxes and long hoes and transporting it as headloads of about $0.009 \mathrm{~m}^{3}$. In a dam of $25 \mathrm{~m}$ height, the fill was spread in thin layers, watered and compacted by foot: the layer thickness was allowed to increase with dam height from $0.07 \mathrm{~m}$ to a maximum of $0.15 \mathrm{~m}$. In Spain, the $28 \mathrm{~m}$ high Ponton de la Oliva dam was built by 1500 convicts, 200 labourers aided by 400 beasts of burden and four steam engines (Smith, 1970). Compaction was by herds of animals driven backwards and forwards over the fill.

In current construction, it is not uncommon to find compaction by vibrating rollers of rockfill in 2 m layers.

The equipment used to construct Grand Maison $(140 \mathrm{~m})$ had a total power during the 1983 construction season of 52500 h.p. The consumption of diesel fuel was $1.881 / \mathrm{m}^{3}$ of placed fill. During 1981, when fill levels were lower, the consumption was $1.601 / \mathrm{m}^{3}$. At Sulby $(60 \mathrm{~m})$ rockfill dam on the Isle of Man the consumption was $1.851 / \mathrm{m}^{3}$ and at Carsington $(35 \mathrm{~m})$ $1.75 \mathrm{1} / \mathrm{m}^{3}$. The total volume of Grand Maison is $12.9 \mathrm{hm}^{3}$ and its construction used about $22 \times 10^{6} 1$ of fuel oil. Compared with the amounts of irreplaceable oil consumed routinely for heating, electricity generation and transport, this is a very small amount and represents a sound investment, contributing to the supply of hydro-power-a replaceable resource.

The efficiency of earth placing equipment has made it attractive for concrete dam construction. The use of rollcrete (Lowe, 1962) and the development of special mixes (Dunstan, 1981) have led to the rolled concrete dam. There are many examples in various parts of the world: those in Japan have been described by Yamauchi, Harada, Okada \& Shimada (1985).

\section{Potential danger}

The large potential energy of water stored behind a dam makes its uncontrolled release dangerous. Dam failures that have allowed rapid escape of reservoir water are relatively few, despite the ever increasing number of dams. An analysis by Schnitter (1979) of information collected by ICOLD showed that the percentage of embankment dams built in a given year, that subsequently failed allowing the release of water, has fallen at least tenfold during the first half of this century. da Silveira (1984), analysing further material collected by ICOLD on deterioration, has shown that the probability of failure of embankment dams has fallen from 0.028 in the period 1900-20 to 0.0035 during 1960-75. The causes of failure of embankment dams are almost equally divided between
(a) erosion by overtopping
(b) rotational slips
(c) internal erosion.

Improved hydrological studies and methods of predicting flood flows are reducing overtopping risks but there is a geotechnical requirement to improve resistance to accidental overtopping. British Flood Studies Reports since 1933 have provided design methods that have largely overcome overtopping, but recent introduction of the concept of a probable maximum flood (PMF) has indicated that the spillways of many old dams are inadequate. The return period of a PMF cannot be well defined, but is clearly very long. The inadequate spillways of many dams more than 100 years old have successfully prevented overtopping and a solution to the problem may be to improve erosion resistance to permit emergency overtopping.

The 140 year old Toddbrook Dam $(20 \mathrm{~m})$ near Whaley Bridge has had a wide concrete auxiliary spillway built over its crest, and Mackey (1985) has described the reinforcement with interlocking concrete cellular blocks of the crest and downstream slope of an old dam. A current research programme by the Construction Industry Research and Information Association is studying the effectiveness of various forms of surface reinforcement that may be used on low embankment dams.

Failure by rotational slip usually occurs during construction, before there is water in the reservoir: various aspects will be discussed in the next section.

Failure by internal erosion is much more dangerous because it can occur suddenly, with a full reservoir. It is the most serious current geotechnical problem relating to embankment dams. Various aspects including hydraulic fracture will be discussed in the Paper.

The following four examples illustrate failure by overtopping and internal erosion.

Estrecho de Rientes $(45.7 \mathrm{~m})$ built $1755-89$ in Spain was probably the world's highest embankment dam at that time. The reservoir filled for the first time in February 1802 and the dam breached in April releasing a flood that destroyed part of the town of Lorca, drowning 600 people. The exact cause of failure was not determined.

South Fork $(21.9 \mathrm{~m})$, Pennsylvania, was built of earthfill with a 1:2 upstream slope and a downstream shoulder of rockfill at 1:1.5. The crest width and freeboard were $3 \mathrm{~m}$. Overtopping occurred during the day on 31 May 1889 and the 


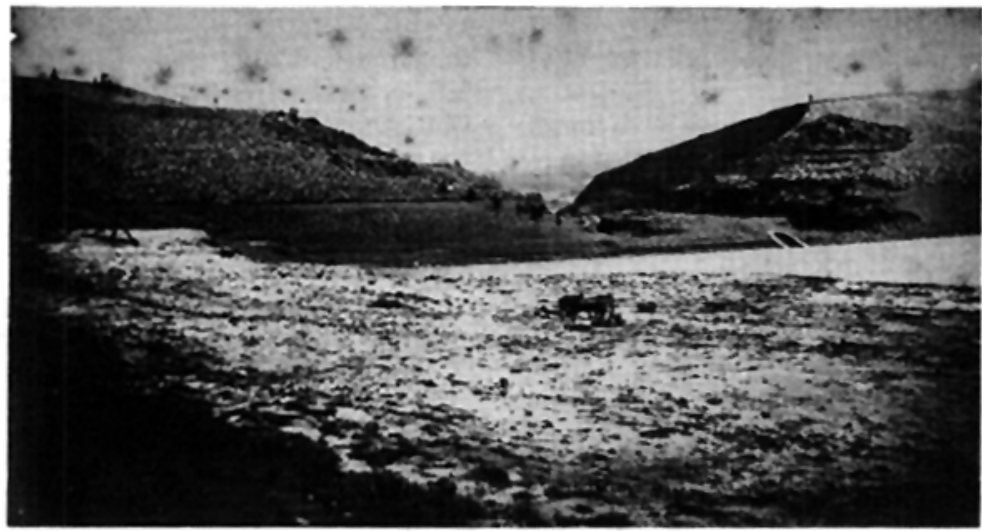

Fig. 2. Breach in Dale Dyke after failure in 1864

dam withstood $0.5 \mathrm{~m}$ depth of water over the crest for $3 \frac{1}{2}$ hours before a breach formed: the resulting flood caused the loss of 2209 lives.

Dale Dyke $(29 \mathrm{~m})$, England, failed on first filling in March 1864. Fig. 2 shows the breached dam from upstream. The dam contained a central narrow puddled clay core and had twin cast iron pipes of $0.45 \mathrm{~m}$ dia. passing through it to the outlet control valves at the downstream toe. In a reassessment of the Dale Dyke failure, Binnie (1978) uncovered evidence, ignored by the enquiry, of a whirlpool seen during a calm period several days before the failure, indicating a substantial flow entering the upstream slope at about three-quarters of the dam height. The reason that this did not cause visible flow from the downstream slope may be due to the loose nature of the fill and the presence of a large rockfill toe which acted as a drain. Subsequently, Binnie (1981) found evidence that there had been a large issue of water from the foot of the embankment where the breach occurred. He also uncovered evidence that substantial steps had been left in the longitudinal section of the cut-off trench. During construction a 'spring' had been found and excavation was continued to expose the source, leaving an almost vertical face $10 \mathrm{~m}$ high and another $3 \mathrm{~m}$ high under the central part of the dam. Differential settlement of the puddled clay across the discontinuities could have produced sufficient reduction of total stress to permit hydraulic fracture. Binnie (1877) condemned vertical steps in the floor of cut-off trenches, stating

'owing to the unequal depths of puddle that occurs at the steps, the superincumbent weight has caused that on the deeper side to settle more than that on the higher, and so produce a vertical crack or fault in the puddle which has led to serious consequences'.
Teton Dam $(93 \mathrm{~m})$, Idaho, is the highest embankment dam to have failed, Fig. 3. It was built mainly from silt across the Teton River canyon in volcanic rocks containing interconnecting open joints and voids. The site was chosen for the situation of the reservoir to store irrigation water for the surrounding silt-covered plains, not because it was suitable for a dam. It failed on first filling when the reservoir level was only $1 \mathrm{~m}$ below the spillway gate cill $(9.2 \mathrm{~m}$ below the crest). No instruments had been placed in the dam and assessment of behaviour depended on visual observations. Although a regular inspection was made for any signs of leakage near the downstream toe as the reservoir approached top water level, the initially very low regional water-table combined with the high overall per-

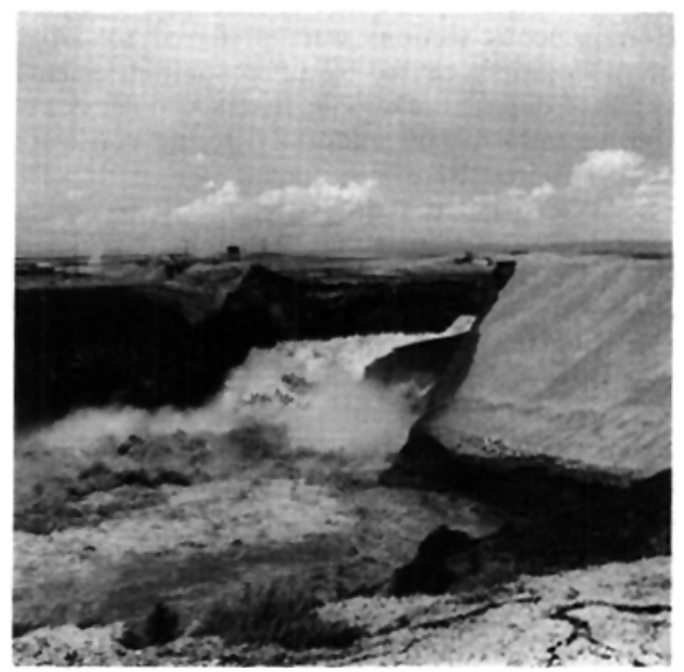

Fig. 3. Teton Dam 
meability of the bedrock to prevent any water appearing at the ground surface until two days before failure.

On 3 June 1976, small, clear springs were found on the right abutment about $450 \mathrm{~m}$ downstream of the toe. On the next day some patches of wetness appeared, closer to the toe of the dam, but they gave no cause for concern. On 5 June at 7.00 a.m. there was a steady flow of water coming from the toe, adjacent to the right abutment. Muddy water was soon found to be issuing from the downstream slope of the dam itself and within a few hours backsapping had produced a substantial channel carrying a considerable discharge of earth-laden water and a whirlpool had formed in the reservoir in line with the discharge. Despite the efforts of two bulldozers to check the backsapping, the channel rapidly eroded back to the crest of the dam, which breached at 11.57 a.m., less than five hours after seepage was first seen coming from the dam itself. Six hours later, the $27 \mathrm{~km}$ long reservoir was essentially empty and the breach in the dam showed that $2.5 \times 10^{6} \mathrm{~m}^{3}$ of fill adjacent to the right abutment had been lost. Because the developments before failure occurred during daylight and warning had been given to the authorities, most people were able to escape the ensuing flood.

\section{PORE PRESSURE AND STABILITY}

Dam engineers are faced with the sometimes conflicting requirements of watertightness and stability. Relatively fat clays were used for many almost homogeneous section dams in India (Strange, 1898) and success may be partly attributed to construction by thousands of workers carrying fill as headloads and compaction in 75$150 \mathrm{~mm}$ layers by the feet of men and animals. Homogeneous sections were preferred to avoid stress variations caused by differential settlements in fills of different materials. It was also felt desirable to raise the fill uniformly during construction. Failures were not uncommon and were associated with the downstream fill becoming excessively wet. Slip surfaces in pure black soil were seen to be smooth, of unctuous appearance, striated by the small particles of contained grit.

During the mid 19th century, it was thought that there was a maximum height to which an embankment dam could safely be built. French engineers were reported as placing the limit at $18 \mathrm{~m}$. Rawlinson (1883), the governmentappointed inspector of the 1864 failure of Dale Dyke, said that he knew that some engineers had been greatly tormented with leaks from beneath earthen embankments and it had been put on record that no dam, if it had to retain a depth of more than $18 \mathrm{~m}$ of water, ought to be constructed of earthwork. He went on to point out, however, that many already existed at greater heights. As late as 1914, Uren (1914) indicated that the limit was $24 \mathrm{~m}$.

'Beyond this height, though many have safely exceeded this in England-notwithstanding the theories of French engineers upon the subject-unless carried out with the utmost care and under the strictest supcrvision, they are troublesome to erect and treacherous when filled, being liable to sudden and unforeseen slips.'

\section{Early piezometers}

Slips that occurred during construction could be dug out and replaced with stronger fill, but it was a different matter with slips that occurred when impounding. There was a desire to see whether water was getting through into the downstream fill. At Waghad Dam $(32 \mathrm{~m})$ begun in 1881 in the Násik Collectorate of India, constructed of a plastic expansive clay $\left(w_{\mathrm{L}}=70\right.$, $w_{\mathrm{p}}=35$ ), a major slip occurred during construction. The homogeneous section had reached $29.5 \mathrm{~m}$ and the slip carried the downstream toe out about $20 \mathrm{~m}$. It was stabilized by drainage using rock-filled trenches cut through to the rock foundation. Attempts to continue construction caused further movement, so the crest was moved upstream and lowered from the design height by $5.1 \mathrm{~m}$ as shown by Fig. 4 . To check on the position of the phreatic line when the reservoir was filled, the British engineers installed standpipe piezometers in 1907 (Nagarkar, Kulkarni, Kulkarni \& Kulkarni, 1981). This may be one of the earliest installations of piezometers in an embankment dam.

The problem of instability in homogeneous dams caused by the phreatic surface reaching the downstream slope was apparent in the USA. Attempts were made to measure its position in cased holes bored into the fill after construction. A rising water level in these holes before impounding had begun revealed construction pore pressures.

A systematic study of the behaviour of embankment dams was started by the US Bureau of Reclamation (USBR) in 1936. The slow response time of open holes was quickly recognized and the Goldbeck earth pressure cell (Goldbeck \& Smith, 1916) was modified by placing a carborundum disc in front of the pressure-sensitive diaphragm to form a remote reading piezometer. These were placed in holes bored on completion of construction and sealed in with concrete backfill. Pore pressures as high as $r_{\mathrm{u}}=0.7$ were measured and found to be slow to dissipate. 

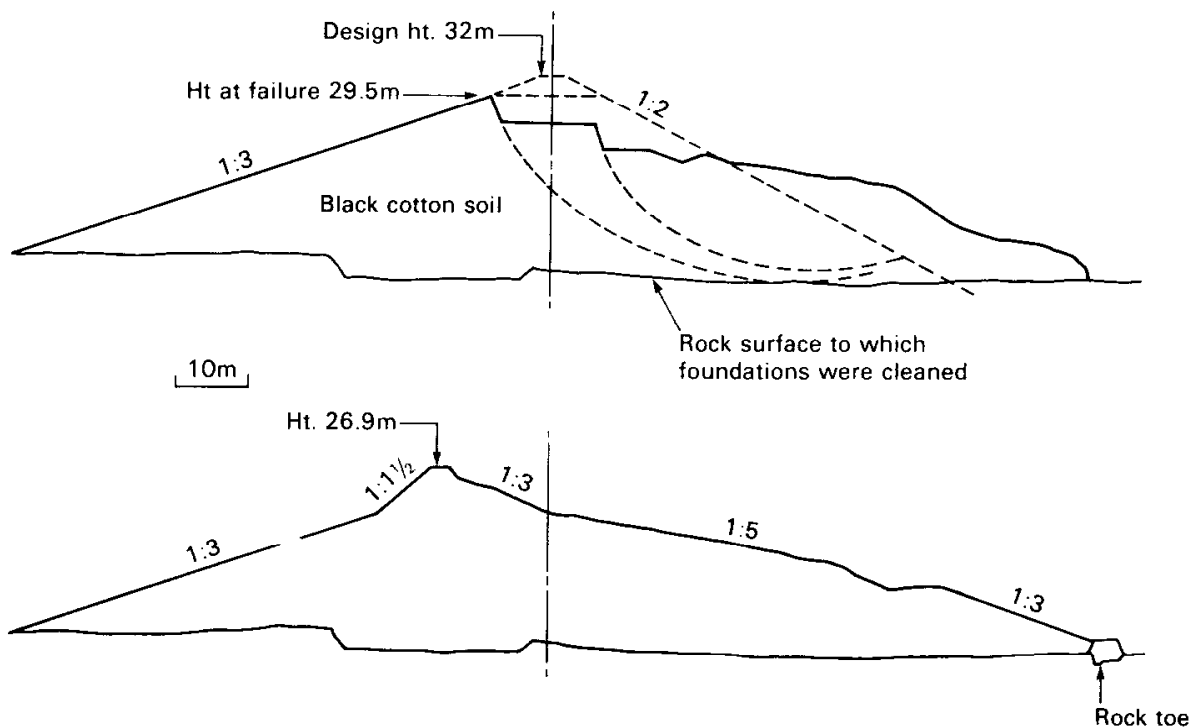

Fig. 4. Waghad Dam: original and redesigned section

Walker (1948) expressed the view that it was therefore not surprising that so many dams had failed during or immediately after construction. Unfortunately, these findings led to a concerted effort to reduce construction pore pressures by the use of low placement water contents, which has had a marked effect on dam design and subsequent behaviour.

Research by the USBR into the behaviour of fill produced methods for predicting construction pore pressures from fill properties and placement air and water contents. Boyle's law gave the pressure of the air, and its solution into the porewater was governed by Henry's law. If the fill was sufficiently compressible and contained little air, the air soon went into solution as total pressures increased and after that $\delta u=\delta \sigma$.

It was found that, with soils that were compacted too dry, subsequent saturation under load could produce a sudden reduction in volume, i.e. collapse settlement. As the placement water content was increased, a value was reached when collapse settlement ceased and this was regarded as a suitable lower limit. It was thought that an upper limit could be specified, according to the magnitude of pore pressure that could be tolerated, but under the overburden pressures of high dams even placement at the lower limit did not prevent pore pressures from developing. A rule therefore evolved that the placement water content should be 1-3\% dry of optimum.

When referring to optimum water content, it is necessary to specify the compaction energy and, in relation to variations from optimum, knowl- edge of $I_{\mathrm{p}}$ is valuable. The standard Proctor test uses $596 \mathrm{~kJ} / \mathrm{m}^{3}$ whereas the USBR compaction test uses $1135 \mathrm{~kJ} / \mathrm{m}^{3}$ and the modified AASHO uses $2630 \mathrm{~kJ} / \mathrm{m}^{3}$. Clearly the USBR optimum water content will be lower than that for the standard Proctor test, but the effect of reducing the water content by $3 \%$ will be much more marked in a soil of low plasticity such as a silt than it would be for a fat clay.

Charles (1979) showed that the change in moisture content required to produce a required change in $c_{\mathrm{u}}$ of a clay fill was a linear function of $I_{\mathrm{p}}$

$$
\delta c_{\mathrm{u}}=-\frac{2 \cdot 3 B c_{\mathrm{u}} \delta w}{I_{\mathrm{p}}}
$$

where $B$ is a constant which for most clays is about 2 .

It is clearly more straightforward to specify a required value of $c_{\mathbf{u}}$ for core fill than to specify placement $w$. Strength specification has been used in Britain during the last two decades (Kennard, Lovenbury, Chartres \& Hoskins, 1979).

It is of interest to note that the twin tube hydraulic piezometer stemmed from damage to a modified Goldbeck unit. Pore pressure measurements were made by increasing the air pressure inside the cell until movement of the diaphragm broke an electrical circuit. The air pressure was then thought to equal the pore pressure. A $6 \mathrm{~mm}$ copper tube containing an electrical wire connected the cell to the instrument house, where a Bourdon gauge measured the air pressure. Condensation in the cell could provide continuation 

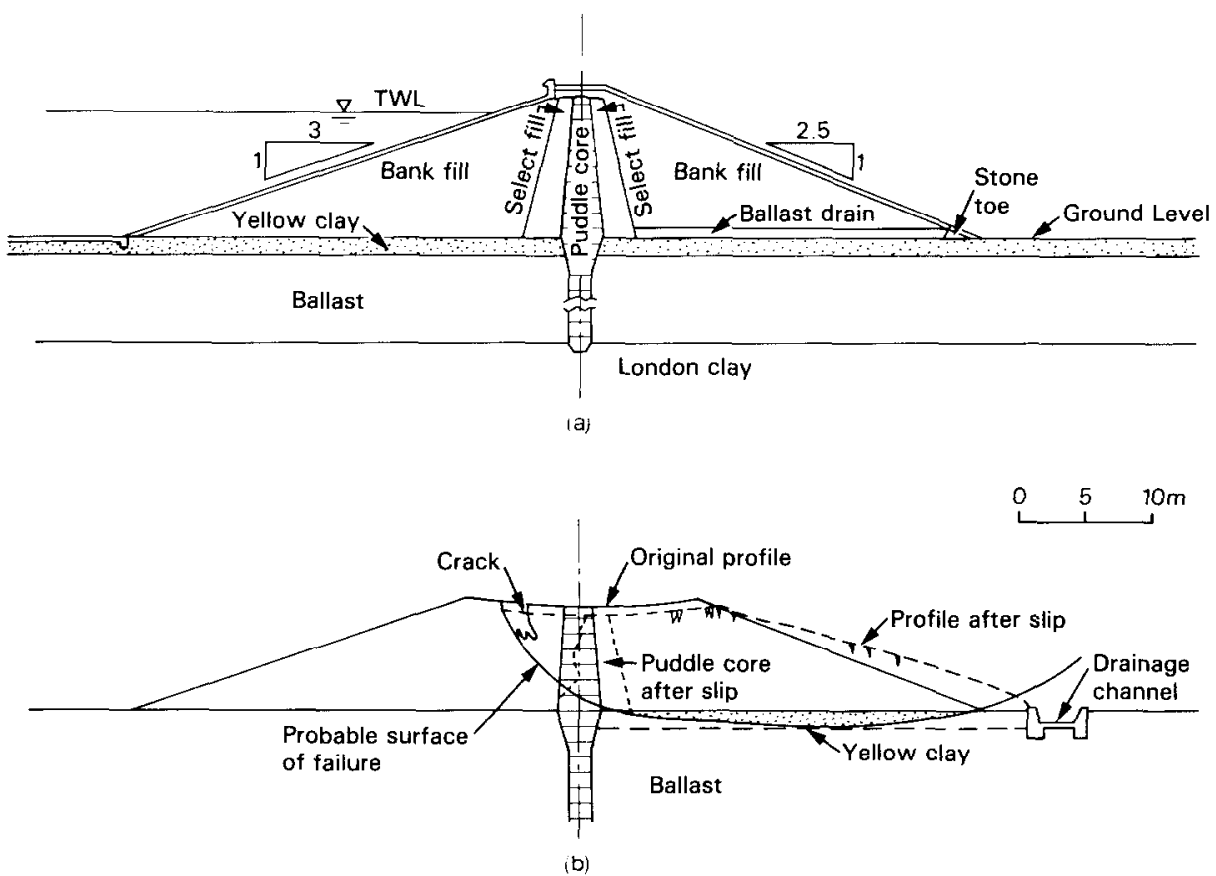

Fig. 5. Chingford Dam, showing the position of the slip surface: (a) section of the bank as designed; (b) section through the bank after slip

of the electrical circuit until excessive diaphragm deflexions had been caused; however, cells with ruptured diaphragms allowed the Bourdon gauges to respond to pore pressure all the time. A second connecting tube was provided so that the tubes could be filled with water to improve the response time.

\section{Speed of construction}

Whatever the concept by Victorian engineers of water in fill, advice given by Strange (1898) would allow for pore pressure dissipation and improve stability. He recommended that the fill should not be raised more than $9 \mathrm{~m}$ during one season and that a completed dam should be left for at least one season to consolidate before filling the reservoir.

The effect of rapid construction was demonstrated by the failure of Chingford Dam during construction in 1937. The bank, to be $10.4 \mathrm{~m}$ high, was built with Caterpillar D8 tractors pulling tracked Athey tipping waggons. The fill level was raised $4 \mathrm{~m}$ during the month before the rotational slip. Investigation by the Building Research Station (BRS) (Cooling \& Golder, 1942) showed that the slip surface passed through the puddled clay core (Fig. 5) and a layer of soft yellow clay. This had been left in the foundation under the gravelly downstream shoulder at the insistence of the owner/designer, against the recommendation of the contractor. The failure involved about $100 \mathrm{~m}$ length of bank that moved out bodily $4.3 \mathrm{~m}$, causing the fill surface to drop about $0.6 \mathrm{~m}$.

Values of $c_{u}$ were measured with undrained tests on 'undisturbed' samples on site in the portable autographic compression apparatus and at the laboratory in ring shear under zero normal load. (Jenkin had developed his ring shear apparatus expressly to obtain $c$ distinct from $\varphi-$ Cooling (1936).) For the yellow clay, average $c_{\mathrm{u}}=14 \mathrm{kN} / \mathrm{m}^{2}$ and, for the puddled clay, $c_{\mathrm{u}}=10$ $\mathrm{kN} / \mathrm{m}^{2}$. When used in a two-circle modification of the Swedish stability analysis, these values gave a factor of safety of unity.

Eight months after the failure, when rebuilding began, tests on the yellow clay under the removed fill showed $c_{\mathrm{u}}=36 \mathrm{kN} / \mathrm{m}^{2}$ : an increase of $22 \mathrm{kN} /$ $\mathrm{m}^{2}$ since failure. The vertical load on the clay layer was about $144 \mathrm{kN} / \mathrm{m}^{2}$ and Skempton calculated values of pore pressures at the centre of the layer for various times after the application of load based on consolidation theory and laboratory values of $c_{\mathrm{v}}$. At 37 days and 277 days, corresponding to the times of failure and rebuilding, the calculations showed $u=115 \mathrm{kN} / \mathrm{m}^{2}$ and $u=5 \mathrm{kN} / \mathrm{m}^{2}$ respectively, i.e. an increase in effective stress of $110 \mathrm{kN} / \mathrm{m}^{2}$. Drained shear box tests 


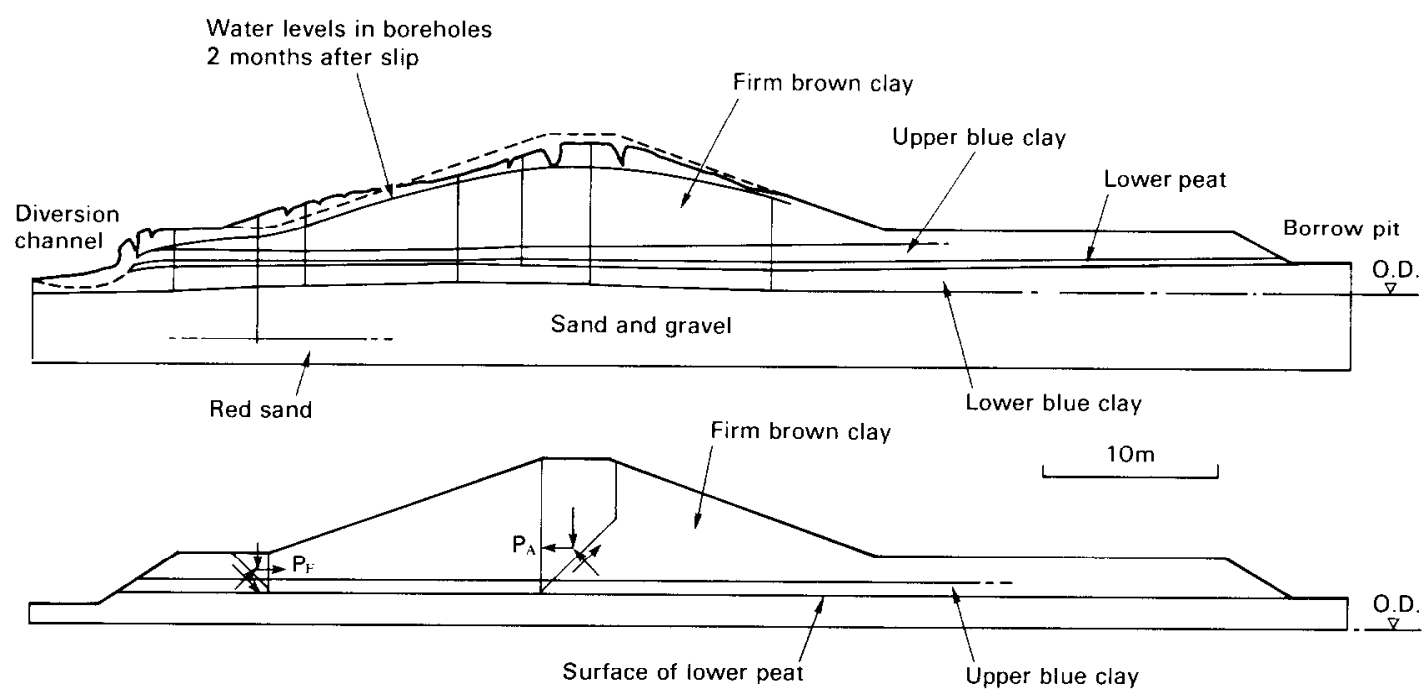

Fig. 6. Flood bank for the River Don at Thorpe Marsh

showed this to cause an increase of $c_{u}=30$ $\mathrm{kN} / \mathrm{m}^{2}$, which compared favourably with the increase measured in the field.

Cooling and Golder, acknowledgeing Skempton's contribution, remarked that with a more permeable foundation layer, such as silt, the method of calculation could be used to control the rate of construction so that the strength of the foundation material should at no time be exceeded

The events surrounding this failure were classic in the annals of British geotechnical engineering because of the interest that they aroused among dam engineers and the attention they drew to the research of the BRS. To protect the contractor's interests, Mowlem's Agent, Wynne-Edwards (who became President of the Institution of Civil Engineers for 1964-65 and was knighted as First Chairman of the Council of Engineering Institutions) brought Terzaghi to the site: he unreservedly approved the BRS report. The evident need for a commercial laboratory to carry out site investigation and to test samples led to the formation of Soil Mechanics Ltd.

Rapid construction also led to the failure of Muirhead $(27 \mathrm{~m})$ in 1941 . Wartime conditions demanded early completion of the dam and the introduction of track laying machinery accelerated placement from $2500 \mathrm{~m}^{3} /$ week to $12230 \mathrm{~m}^{3}$ / week and enabled the upper fill to be placed in a few months. A rotational slip occurred when dam height reached $21.9 \mathrm{~m}$ and an investigation by the BRS showed that it passed through the lower wetter fill. It was not a brittle failure and after initial movement of about $1.3 \mathrm{~m}$ further placement of 0.46 In of fill caused $0.15 \mathrm{~m}$ horizontal movement. The upstream slope was stabilized by rockfill toe weighting and, as at Waghad, the crest was moved upstream and lowered $5 \mathrm{~m}$ below design level. Although pore pressures were not measured, the failure was clearly due to high values that had developed under the rapid height increase. As a result, standpipe piezometers were placed in the fill of the nearby Knockendon Dam that was currently under construction. These piezometers, placed in 1944, were probably the first to be used in an embankment dam in Britain. This work was described by Banks $(1948,1952)$. They showed $r_{\mathrm{u}}>0.5$ but stability had been ensured: after Muirhead, design was modified to include a key of granular fill placed in excavation through the existing downstream fill and a substantial toe weighting berm upstream.

An early example of analysis using effective stresses was that of the failure of a small flood bank in 1948. The $5.5 \mathrm{~m}$ bank (Fig. 6) built of brown clay $\left(c_{u}=29 \mathrm{kN} / \mathrm{m}^{2}\right)$, on a softer blue clay containing a layer of peat $\left(c_{\mathrm{u}}=13 \mathrm{kN} / \mathrm{m}^{2}\right)$ failed shortly after construction, when a new river channel was excavated, thereby removing toe support. A total stress analysis gave $F=1.6$ and it was suggested that the shearing resistance of the peat under and beyond the toe had been reduced by the redistribution of pore pressure along the layer from the higher construction values under the bank. This concept was checked by placing 12 hydraulic piezometers in the peat across the section of new bank to be built on the opposite side of the channel. Measured values and details of the analysis were given by Ward, Penman \& Gibson (1955). Like Chingford, failure was along a soft layer in the foundation, but the 

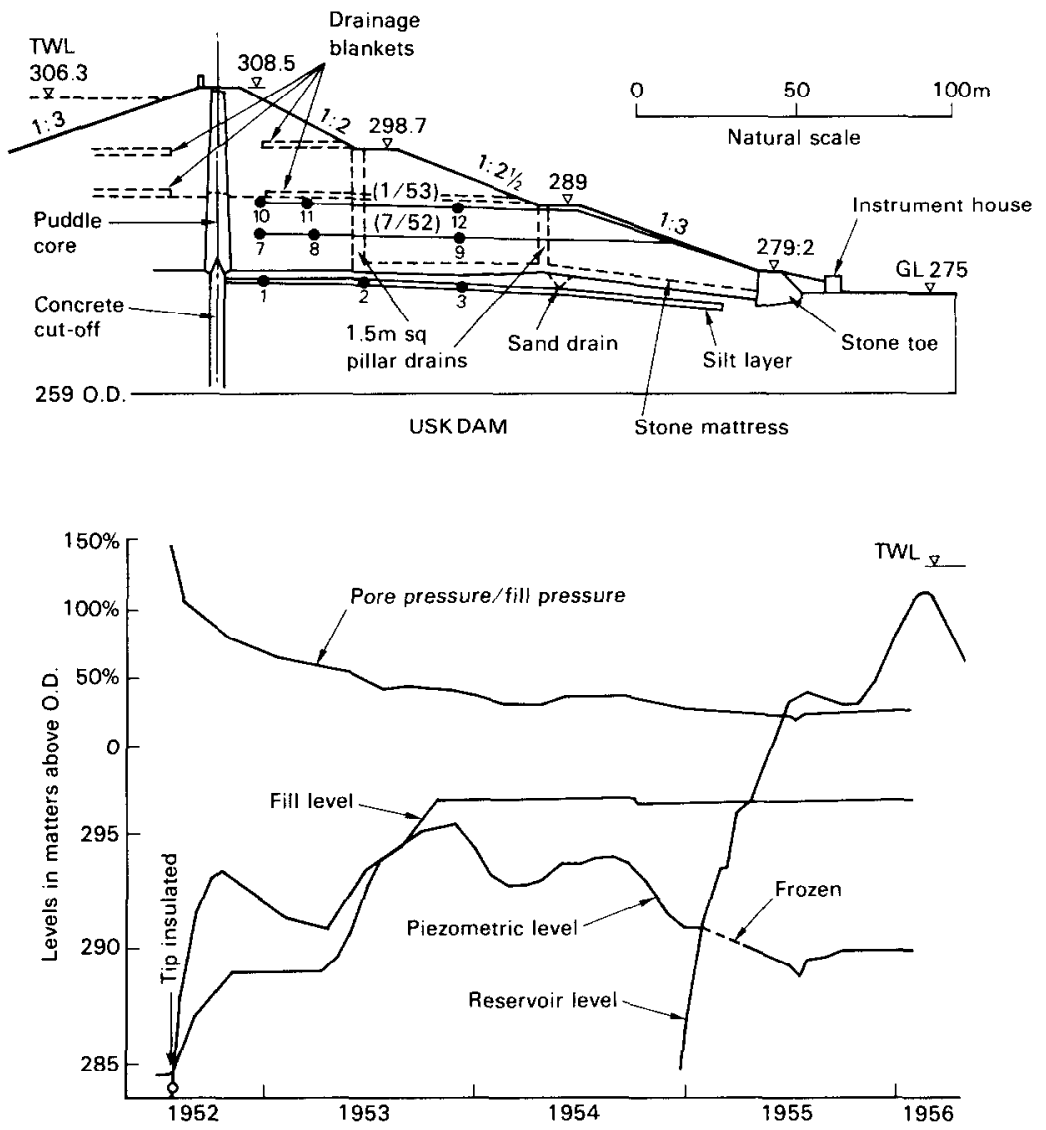

Fig. 7. Usk Dam: section and measured pore pressure at tip 9

failure surface was analysed by wedge shapes rather than by circular arcs.

\section{Usk Dam}

The BRS became involved in the Usk Dam $(33 \mathrm{~m})$ when a silt layer was discovered in the foundation during excavating for a stilling basin. After designing sand drains for the silt, two tube hydraulic piezometers developed from the USBR type were installed to check pore pressures in the silt layer. It was then agreed with the consultants that the apparatus would be extended so that tips could be placed in the fill to observe construction pore pressures for research interest. The findings were rather remarkable.

Three tips were placed at mid-height of the first season's fill during July 1952, at the positions shown by Fig. 7, and measured values gave $r_{\mathrm{u}}>$ 1.5. Even though the initial pressures quickly fell, pore pressures towards the end of the winter shut-down period were too high for stability of the completed dam. Under the direction of Skempton and Bishop, standpipe piezometers were driven into the fill on an adjacent section and confirmed the high pressures measured by the two tube piezometers-decorators' stepladders had to be used to measure water levels in the standpipes! Details of this experience have been given by Penman (1979).

Stability was ensured by changes in the design and construction method. Horizontal drainage layers were placed in the fill to reduce drainage path lengths and placement water content was reduced by winning the fill with face shovels instead of scrapers. By the end of construction, $r_{u}$ values had fallen sufficiently to satisfy effective stress stability analysis based on the Swedish method of slices.

This experience led to the use of horizontal drainage layers in the shoulders of numerous dams constructed of clayey fill, e.g. Selset, Derwent, Staunton Harold, Altnahinch, Diddington, West Water, Chelmarsh, Backwater and Carsington. Horizontal drainage layers at a vertical spacing of $3 \mathrm{~m}$ had been provided in the moraine fill forming part of the downstream shoulder of 
Harspranget Dam $(50 \mathrm{~m})$ built in Sweden 1946-51 (Westerberg, Pira \& Hagrup, 1951).

The problem of $r_{v}>1.5$ in the Usk fill was particularly intriguing because it is known that pore pressures in clayey fills must be below atmospheric (i.e. there must be pore suctions) to enable the fill to support construction machinery. To avoid unacceptably deep ruts $c_{u}>40 \mathrm{kN} / \mathrm{m}^{2}$ (Dennehy, 1979) and this implies pore pressures that are less than $-50 \mathrm{kN} / \mathrm{m}^{2}$ near the fill surface. It is evident that a piezometer tip must be strong enough not to be affected by total pressures and that its intake filter must be fine enough to exclude soil particles to separate porewater pressure from total pressure. The filters at Usk were $51 \mathrm{~mm}$ dia. carborundum discs similar to but of much larger area than those used by the USBR. Cooling, from his experience with building stones and the use of the suction plate apparatus, suggested that, if porewater suctions were to be measured, the pores of the intake filter should be small enough not only to exclude soil particles but also to exclude air. Owing to surface tension and curvature of the meniscus in a partly saturated fine-grained soil, the pressure of air in the pores is greater than that of the water. In a similar way, a saturated, fine-pored intake filter can prevent the ingress of air because of the differential pressure set up by the curved menisci at the entrance to each pore. For the filter to be successful, it must have uniform-sized pores: special materials are required to obtain good permeability with small enough pore sizes. Rogers (1935) designed a tensiometer to measure porewater suction in agricultural soil: its unglazed earthenware pot could support suctions of 0.8 bar. Black, Croney \& Jacobs (1958) used a tensiometer with a sintered glass filter with a pore size of less than $1.5 \mu \mathrm{m}$ that could measure a suction of 1 bar. Work at the BRS and Imperial College led to the fine-pored piezometer tip (Fig. 8) described by Bishop, Kennard \& Penman (1960) that is now in general use for hydraulic piezometers in fill.

A comparison was made of coarse and fine filter units at Chelmarsh Dam by installing an electrical piezometer with a coarse filter adjacent to a Bishop tip. The measured pressures, shown by Fig. 9, indicate that the coarse filter instrument responded to pore air pressure, while the fine filter enabled the much lower porewater pressures to be measured. Increasing total pressures, as the fill was raised, reduced the difference between the two pressures: had the dam been higher, saturation would have occurred, making the pressures the same.

The higher pore air pressures measured by coarse filters leading to $r_{v}>1$ usually only

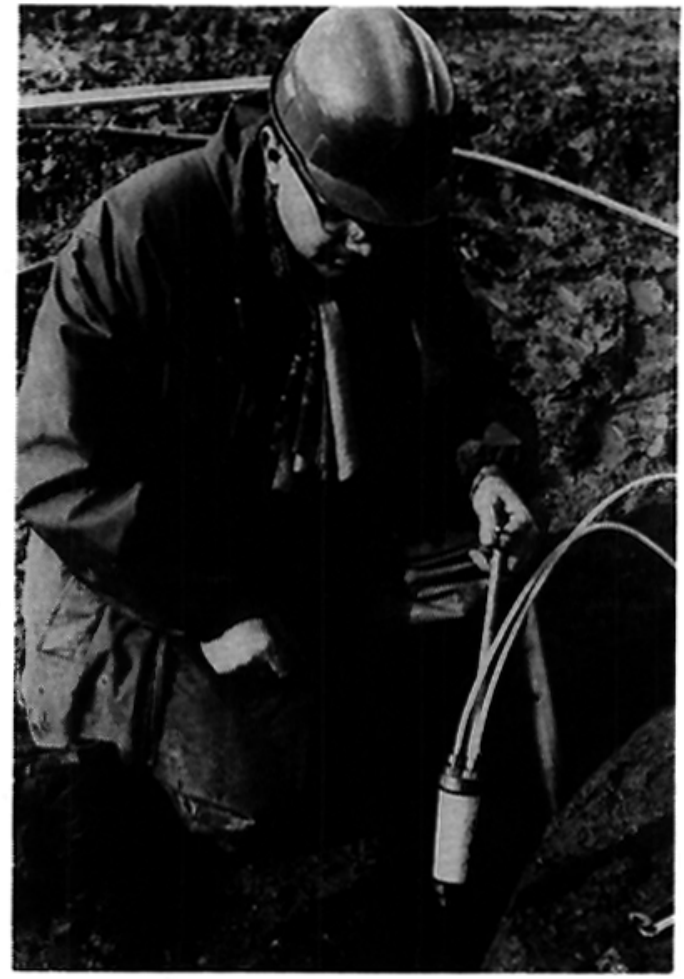

Fig. 8. Bishop tip during installation

occurred under small overburden pressures. Penman (1956) reported two other cases, in addition to Usk, where initially $r_{u}>1$. In both cases $r_{u}$ fell below unity after $1-2 \mathrm{~m}$ of fill had been placed. At Usk the average was $3 \mathrm{~m}$ with a maximum of $4.3 \mathrm{~m}$ of fill.

High pore pressures were measured in the moraine core of Hyttejuvet Dam during construction in 1964. From the Usk experience it was thought that this might in part be due to the use of coarse intake filters. As a check, two pairs of piezometer filters, one coarse and the other fine pored to give a high air entry pressure, were placed side by side in this part-saturated fill. Also, to check on the high pressures deeper down in the core, various types of high air entry pressure piezometers were installed in boreholes. The results of this comparative study of filters with different thicknesses and fineness showed somewhat surprisingly that there were no significant differences in the measured pore pressures. Details of this work were given by Dibiagio \& Kjaernsli (1985).

Beavan, Colback \& Hodgson (1977) have given examples of pore pressures measured in the cores of six dams and have shown that it is not uncom- 


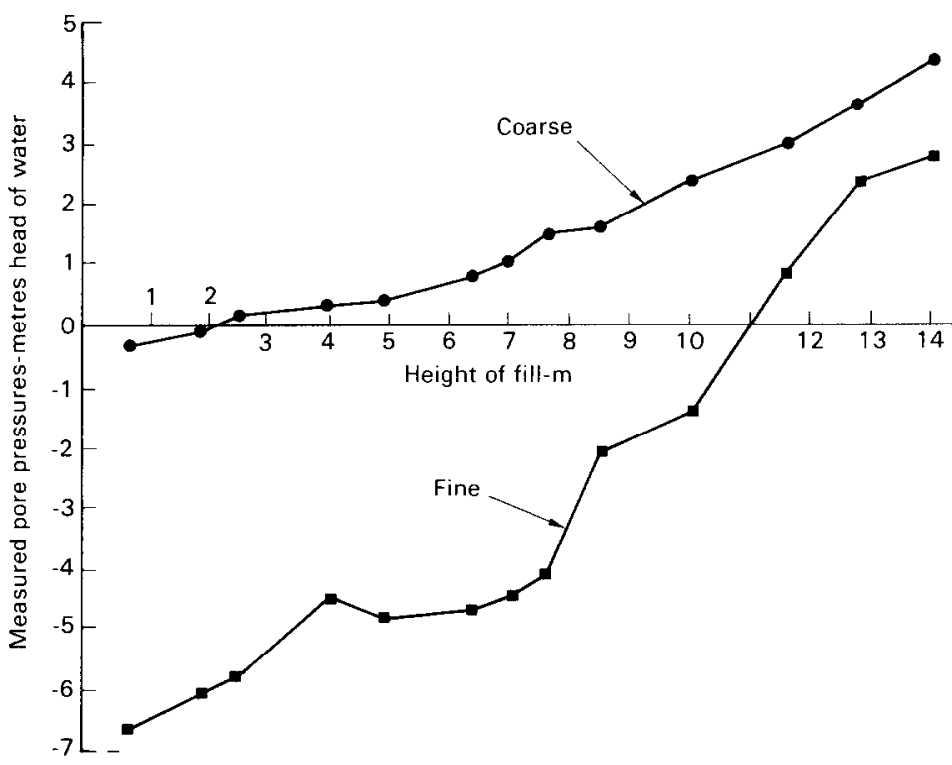

Fig. 9. Pore pressures at Chelmarsh Dam

mon for $\delta u=\delta \sigma_{o}$ during the earlier stages of construction. At Kielder $(52 \mathrm{~m})$ a piezometer in the upstream clay blanket, just upstream of the core, gave $\delta u=1 \cdot 78 \sigma_{0}$ as the fill approached full height. This was probably due to arching of the type observed at John Martin Dam, discussed in the section on total pressures and arching later.

\section{Slip analysis}

Slope stability analysis in terms of effective stresses by the Swedish slices method was made much more rigorous by Bishop (1955) and programmed for computer by Little \& Price (1958). Non-circular analysis by computer was provided by Morgenstern \& Price (1965) and methods of analysis have been developed, for example, by Janbu (1957), Sarma (1973) and Celestino \& Duncan (1981). Several computer programs are now commercially available: with an input of correct values for $\gamma, c^{\prime}, \varphi^{\prime}$ and $r_{\mathbf{u}}$ and the ability to ensure that a realistic shape of slip surface is being analysed, it should be possible to design dams with stable slopes. Skempton (1985) has pointed out that in practice the factor of safety cannot be obtained with an accuracy greater than about $\pm 10 \%$ and due allowance must be made.

The fabric of soil (Rowe, 1972) is broken up by excavation from borrow and spreading and compacting as fill. Thus some fills may approach an 'ideal' uniform soil with fairly constant values assigned to $c^{\prime}$ and $\varphi^{\prime}$. It is recognized (de Mello, 1977) that the failure envelope is frequently curved, so that $\varphi^{\prime}$ is dependent on confining pressure and $c^{\prime}$ may be less than is often assumed. Charles \& Soares $(1984 a$, b) have given methods of analysis that cater for these variations.

If the failure surface is likely to go through the foundation, conditions may be very different. Skempton (1964) drew attention to the effect of fissures and joints and the presence of any existing slip surface in reducing $\varphi^{\prime}$ towards $\varphi_{r}^{\prime}$, introducing the 'residual factor' $R$, which may be considered as the proportion of the total slip surface in the clay along which its strength has fallen to its residual value. In the case of reactivation of an old slip, $R=1$, whereas in clays which are not fissured or jointed (new puddled clay and possibly some compacted clayey fills), the value of $R$ approaches zero.

A variation in the stress strain properties of different types of material through which a potential slip surface may pass, i.e. clay core, compacted shoulder fill and foundation, can lead to progressive failure. Strains within a soft clay core may be sufficient to carry a stiffer shoulder fill or foundation clay over the peak to various reduced residual values. Such reductions, occurring at first locally, can throw extra stress on to adjoining sections of the forming slip surface, leading to progressive failure.

In the light of this knowledge, it is interesting to consider three recent failures involving the upstream shoulders of dams.

Three examples of slips

At Açu Dam $(40 \mathrm{~m})$ a slip occurred on 15 December 1981 during construction when it was 


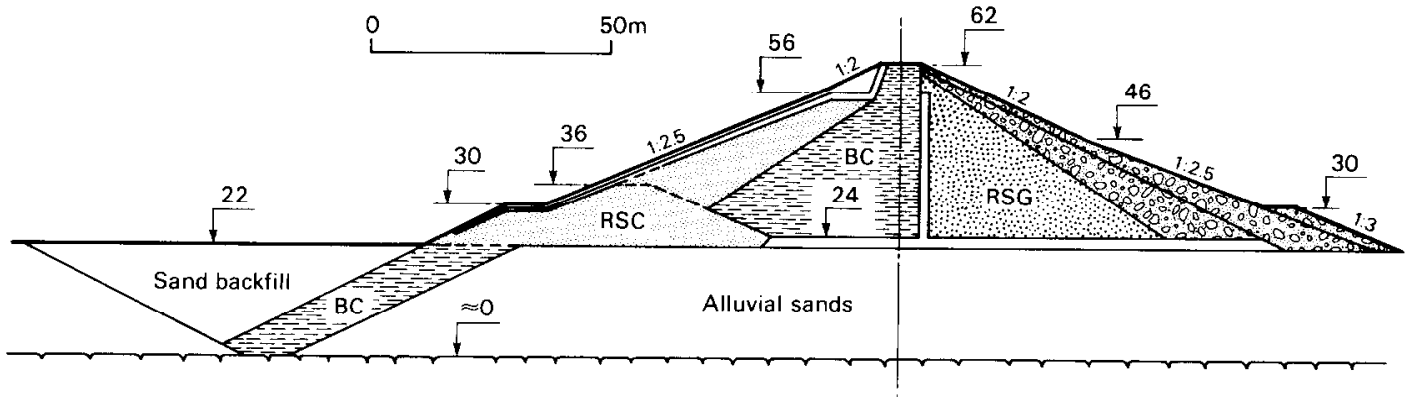

(a)

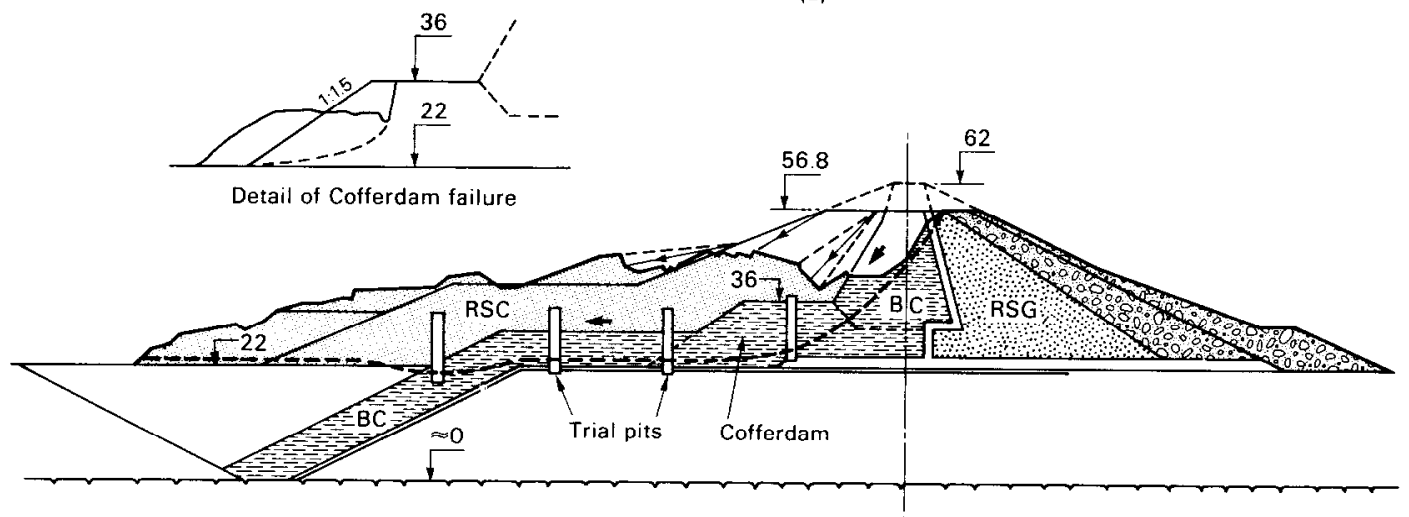

(b)

Fig. 10. Açu Dam: (a) original design; (b) failed section

still $5.2 \mathrm{~m}$ below crest level. The foundation was $22 \mathrm{~m}$ of sand overlying bedrock with a watertable close to ground level. A dark grey-black flood plain silty clay (BC) and an unsaturated red terrace clayey sand and gravel (RSC) were available as fill. A fill with greater gravel content (RSG) was obtained by selection in the borrow area. An original design for the dam is shown by Fig. 10(a). An international specialist consultant was called in to advise on instrumentation and rapid drawdown conditions. He suggested that material RSC would not be sufficiently impervious to provide the link between below ground cut-off and the core. He therefore proposed a modified design, to which the dam was built, with a horizontal layer $7 \mathrm{~m}$ thick of material BC over the sand to connect the cut-off to the core.

At an early stage of construction, a coffer-dam $14 \mathrm{~m}$ high with an upstream slope of $1: 1.5$ was built from material $\mathrm{BC}$ just upstream of the core position (Fig. 10(b)) in little more than a month. Just after construction, two slips occurred, as shown by the coffer-dam detail, each about $150 \mathrm{~m}$ long and separated by some distance, involving about $16 \times 10^{4} \mathrm{~m}^{3}$ of the clay fill. In the absence of pore pressure measurements, a back analysis by total stresses was used and showed $c_{\mathbf{u}}=49$ $\mathrm{kN} / \mathrm{m}^{2}$.

The coffer-dam was repaired with a slope of $1: 2.5$ and the clay layer was placed over the sand, initially in accordance with good practice at a placement water content that was wet of optimum. It had apparently been agreed that for material $\mathrm{BC} \varphi^{\prime}=20^{\circ}$, but discussion on the values to be assigned to $c^{\prime}$, probable pore pressures and the use of circular arcs in stability analysis were still continuing as construction reached a height of $34.8 \mathrm{~m}$.

The failure occurred in about 30 minutes over a length of about $600 \mathrm{~m}$, causing the construction surface to fall $15 \mathrm{~m}$ and the upstream toe to move $25 \mathrm{~m}$ horizontally. First signs had been tension cracks in the level construction surface along the downstream edge of the core. Trial pits revealed slip surfaces in the lower part of the clay blanket, as shown by Fig. 10. A back analysis using total stresses gave $c_{\mathrm{u}}=48 \mathrm{kN} / \mathrm{m}^{2}$, showing remarkable agreement with the value obtained from back analysis of the coffer-dam failures. Conventional unconfined compression tests gave values of $c_{\mathrm{u}}=$ $80-90 \mathrm{kN} / \mathrm{m}^{2}$. Intensely laminated layers were found in the trial pits, thought to have been 
caused by the earth-moving and compacting machinery remoulding, shearing and laminating the soft silty clay. The clay has been found to have a high salt content and strength parameters $c^{\prime}=10 \mathrm{kN} / \mathrm{m}^{2}$ and $\varphi^{\prime}=18^{\circ}$. A back analysis using effective stresses with these parameters has given an average value for core and blanket of $r_{\mathrm{u}}=0.4$ (Costa Filho, 1984).

Details of this failure were published by de Carvalho (1982), de Mello (1982) and Pessoa (1982).

The construction of San Luis Dam $(116 \mathrm{~m})$ in California during 1963-67 incorporated several low hills in its $3 \frac{1}{2}$ mile length. It forms the largest off-stream reservoir in the USA-its $2.5 \times 10^{9} \mathrm{~m}^{3}$ capacity is pumped from the Californian Aqueduct. It was first filled in 1968.

The slip in the upstream slope, described by Kramer (1982) was first discovered on 14 September 1981 and found to be moving at $150 \mathrm{~mm}$ per day after an extended drawdown. It occurred where the dam was $61 \mathrm{~m}$ high and had been constructed over a hillside, as shown by Fig. 11. By 10 October 1981 , it was moving at up to $300 \mathrm{~mm}$ per day and had formed a steep scarp 7.6-9.1 m high, $12-15 \mathrm{~m}$ upstream of the crest blacktop road which contained cracks $25 \mathrm{~mm}$ wide. The reservoir level was already below the toe of this part of the dam and a toe weighting berm was constructed to stabilize the slip.

An investigation found that a layer up to $6 \mathrm{~m}$ thick of highly plastic clayey head deposit had been left on the lower part of the 1:4 foundation slope and had softened under full reservoir. For the material with $I_{\mathrm{p}}=45-50, \varphi^{\prime}=16-17^{\circ}$. Consultant T. M. Leps, who took part in the investigation, has provided the added information that in tests with modest deformation values fell to $\varphi_{\mathrm{r}}{ }^{\prime}=12^{\circ}$. Further analysis has been made by Chugh (1986).

Four tunnels pass through the bedrock to the intake structure and any leakage from them could pass through some of the sandstone seams to affect the clayey head deposit. Piezometers have been installed and have indicated a slight rise in pore pressure when water was being pumped into the reservoir.

The difficulty of predicting an event of this nature is emphasized by the facts that on $25-28$ February 1981, only seven months beforehand, the Department of Water Resources (DWR) and the USBR had reviewed the dam as part of the 'Safety evaluation of existing dams programme'. In addition the DWR-USBR had completed the five-yearly inspection on 4 September 1981, only ten days beforehand.

The failure of the upstream slope of Carsington Dam $(35 \mathrm{~m})$, almost at the end of construction, has been described by Skempton \& Coats (1985). Fill placement had been stopped for three days by heavy rain and a longitudinal crack at the downstream edge of the clay was found at 7.30 a.m. on Monday 4 June 1984 when the surfacc was being inspected to see whether it was suitable for placing the remaining 1-2 $\mathrm{m}$ height of fill to bring the dam to full height. As the crack continued to open, attempts were made to seal it and other parallel cracks which formed, with hand-placed fill compacted by a light, selfpropelled roller. Movement accelerated during the next two days, culminating in a large movement during the night of 5-6 June, which exposed a section of the slip surface $10 \mathrm{~m}$ high (Fig. 12) that had passed through the core, causing a horizontal movement at the upstream toe of $13 \mathrm{~m}$. A section where the failure was initiated is shown by Fig. 13. As at San Luis, a small hill had been incorporated in the dam, providing a foundation that sloped upstream. The appearance of the dam was similar to that of Açuafter failure.

The bedrock was a grey carboniferous mudstone, weathered near the surface and covered by a layer of yellow clay. This, with weathered mudstone, was used for the core and less weathered mudstone was used for the shoulders. A grout curtain cut-off was placed some distance upstream of the centre line and connected to the core by a thick wedge of clay that formed an upstream extension of the base of the core. This connected to the layer of yellow clay that was left in place under the shoulder fill on the sloping formation. The clay core, base extension and clay layer formed a convenient path for the slip surface.

Almost a year before the slip, the contractor had constructed a toe weighting berm (in JulyAugust 1983) to support the highest part of the dam. This had followed a reassessment of stability, the details of which were contained in a report by Kennard (1983). Failure started at one end of the berm, then spread along the dam Iength to include the major sections, lcaving a back scarp almost $500 \mathrm{~m}$ long. Work begun during the afternoon of 4 June 1984 to extend and raise the berm was unable to halt the slip.

The dam was well instrumented with twin tube hydraulic piezometers in the core and its base extension, cross-arm settlement gauges etc. Several piezometers had been placed in the weathered mudstone below the yellow clay layer, but there were none at the mid-thickness of the layer to indicate actual pore pressures on that part of the slip surface.

The core had been built to a strength specification and tests made with a hand vane pushed into exposed slip surfaces three days after the 


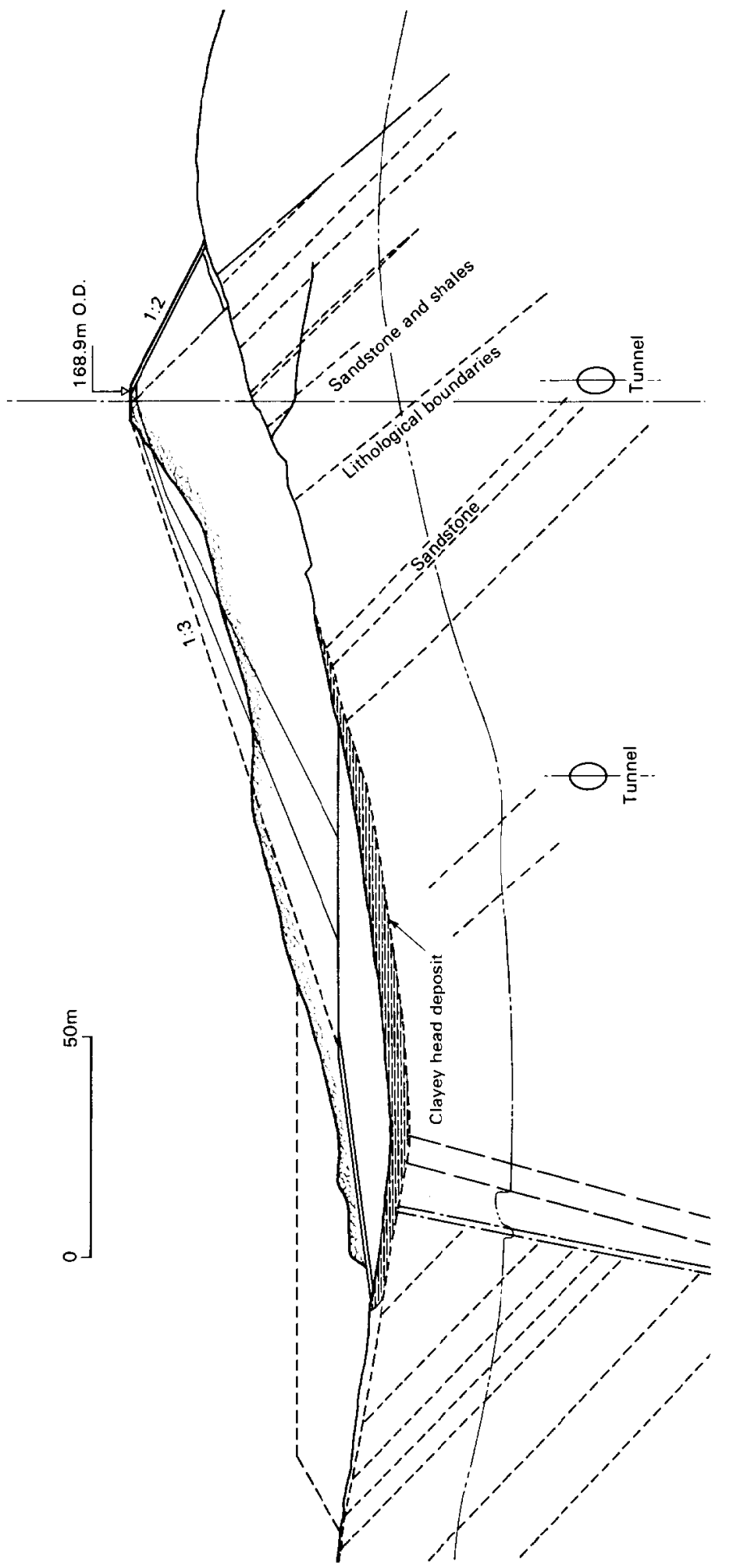

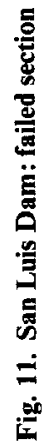




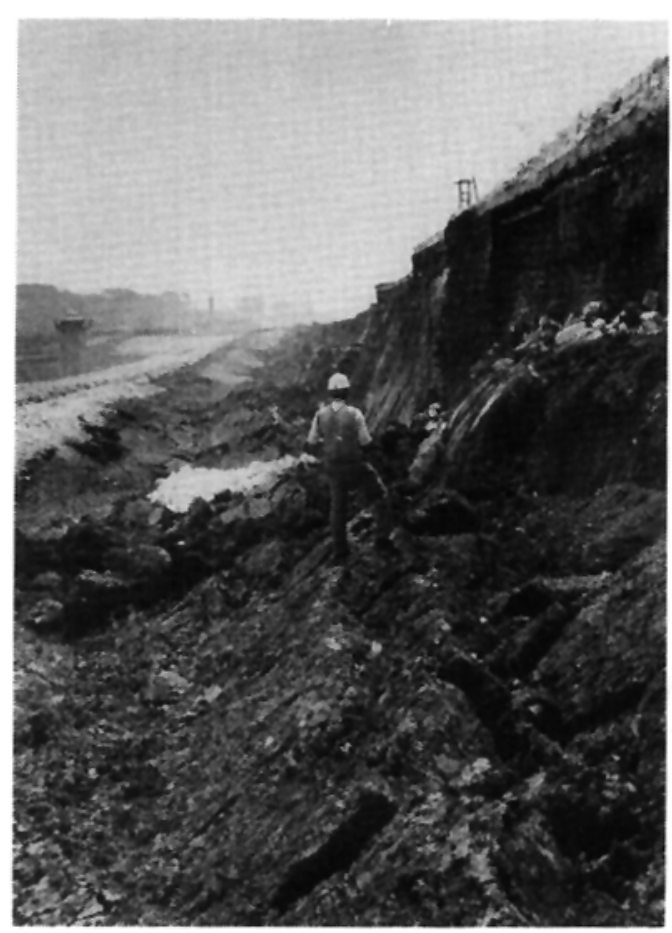

Fig. 12. Back scarp of slip at Carsington

failure confirmed $c_{\mathrm{u}} \approx 70 \mathrm{kN} / \mathrm{m}^{2}$. A total stress analysis based on the shape of the actual failure surface required $c_{\mathrm{u}} \approx 50 \mathrm{kN} / \mathrm{m}^{2}$.

The traditional circular arc type of failure surface of the computer programs used in design checks were not applicable to the failure surface that developed and Skempton \& Coats (1985) report a multiple wedge back analysis that used shapes closely approximating to the surface observed during the failure investigation. This analysis, using known values of pore pressure in the core and its base extension, but assuming $r_{\mathrm{u}}=0$ for the layer of yellow clay and using peak values for strength parameters, indicated a factor of safety of $1 \cdot 4$. This value only fell to unity when consideration was given to prefailure strains in the clay (reducing $c^{\prime}$ to zero) and the existence of pre-existing shear surfaces in the yellow clay layer. Geological evidence showed that the upper part of the yellow clay containing some pebbles was part of head deposits formed by periglacial solifluction: a downslope movement accompanied by shearing. A detailed examination of the clay layer amounting to a total length of $62 \mathrm{~m}$ disclosed pre-existing shears occupying $36 \mathrm{~m}$ length.

At the major section over some areas where the river had removed the yellow clay, the mudstone shoulder fill is believed to be founded on the weathered mudstone. Failure of this section was probably induced by failure of adjacent sections as the slip developed along the length of the dam, but potential progressive failure may have caused this section to have a relatively low factor of safety. These aspects have aroused new interest in the concept of progressive failure along a potential slip surface and have led to the development of more detailed analytical methods. Sideways propagation of a slip from an initial failure position has also been given more detailed consideration and publication of this work is expected after final reports on Carsington have been completed.

These three cases show the common features of clay layers under the upstream shoulder and similar overall size of structure. The shapes of the failure zones at Açu and Carsington were very similar and an adversely sloping foundation existed at San Luis and Carsington. It can be argued that adequate methods of analysis existed that could have provided satisfactory designs, had all the relevant information been obtained from the sites. The failures occurred in countries that have particularly high standards of geotechnical engineering and considerable experience of advanced methods for embankment dam design.

At Açu it must be presumed that allowance had not been made for the effects of progressive failure and that predicted pore pressures had been underestimated. The absence of piezometers prevented a better reassessment of failure conditions. It is agreed that, to form a watertight flexible core, the clay fill should be placed wet of optimum, but if an upstream blanket must be used the most careful consideration should be given to maintaining a practical balance between the desired non-cracking, flexible behaviour, variations in stress strain properties and the requirements of overall stability.

At San Luis and Carsington the slip surface passed through foundation clays that had previously suffered downslope creep or shear movements. Due allowance had not been made for this at San Luis because the presence of these slope wash materials was not detected by the predesign site investigation. At Carsington, the design had failed to recognize the weaknesses of the existing, relatively thin layer of yellow clay (close enough to the surface to have been removed), nor had it made adequate allowance for the effects of progressive failure, which were accentuated by the upstream extension of the core base.

\section{DEFORMATIONS AND ACCEPTABLE MOVEMENTS}

While there is no doubt that shear failure produces unacceptable movements, it is not easy to define the magnitude of movements that are 


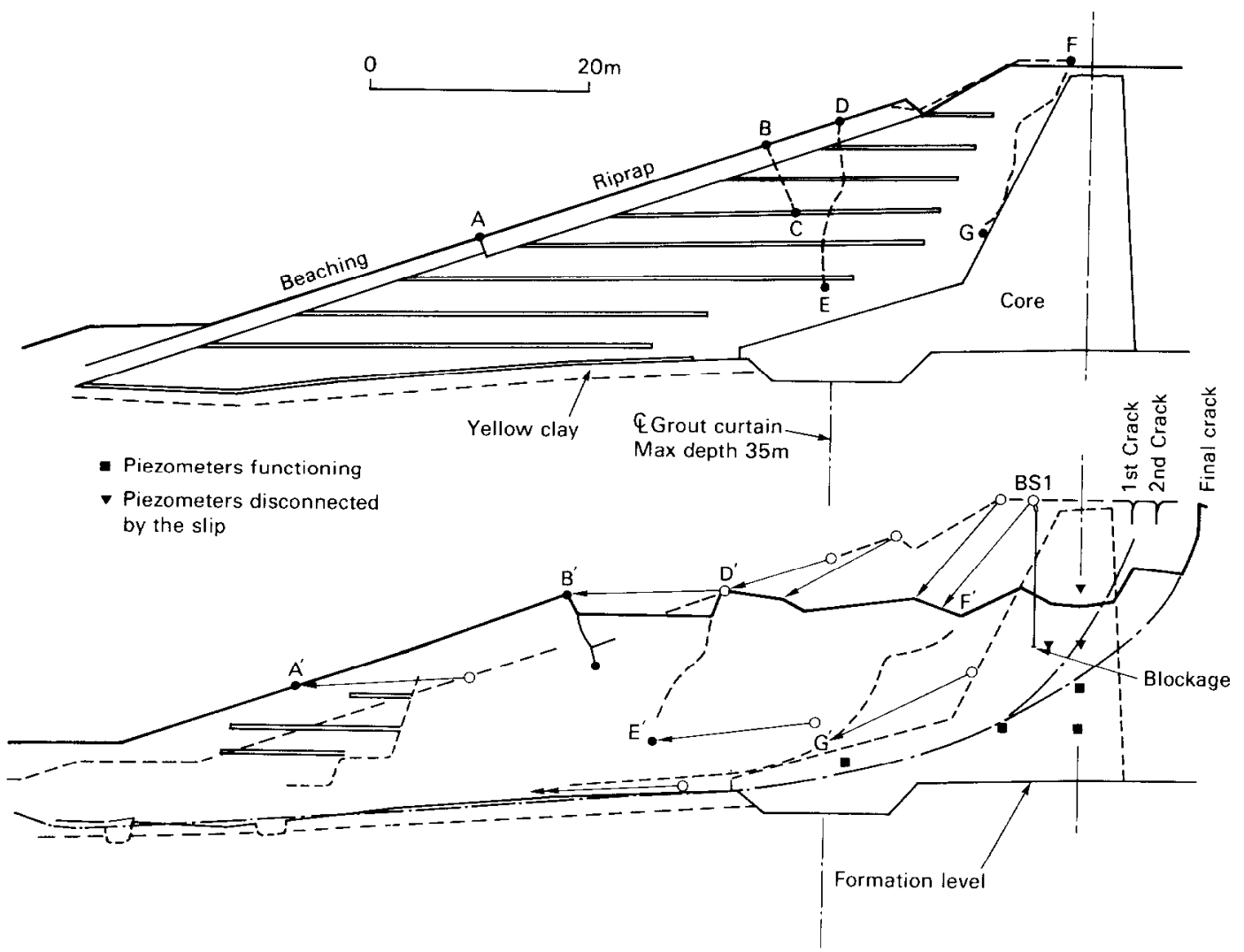

Fig. 13. Carsington Dam : section near origin of failure

acceptable nor, at the design stage, to predict movements. Observations of settlements were among the first to be made on embankment dams because of concern for adequate freeboard and because the development of surveying instruments enabled measurements to be made easily and fairly accurately. Consolidation theory enabled predictions to be made and it became usual to build fill to above the desired crest level, making an allowance such as $0.015 \mathrm{H}$ for postconstruction settlement. Often settlements were less than expected and in several Swedish dams with moraine cores the amount of measured crest settlement could be accounted for by consolidation under self-weight of only the top quarter or third height of core. This led to concern that continuing consolidation of the lower part could induce horizontal cracks through the core.

The effect of differential movements between different fill zones and between fill and abutments, while not apparent during continuous construction, can cause visible cracking during halts in construction. At Mattmark Dam $(100 \mathrm{~m})$, Switzerland, an avalanche damaged the work- camp, causing construction to be stopped when the dam was at about half-height, in August 1965. After two months, transverse cracks across the core and down the upstream slope appeared near the right abutment. After observation for nearly two years, the cracks were repaired by trenching and backfilling. No further cracking was seen during remaining construction and no abnormal leakage developed when the reservoir was filled.

There was a similar experience at Duncan Dam $(36 \mathrm{~m})$ built over a buried canyon $380 \mathrm{~m}$ deep in the valley of the Duncan River, British Columbia. Settlements exceeding $4 \mathrm{~m}$ were expected. To minimize damage, fill near the abutments was kept low while construction of the central length continued, with the intention of completing the abutment sections after settlement. Several weeks after construction had stopped in the abutment areas, transverse cracks $25-80 \mathrm{~mm}$ wide were found right across the core. These were repaired by trenching to depths of $12 \mathrm{~m}$. About $6 \%$ bentonite was added to the core material to increase $I_{\mathrm{p}}$ from 4 to 20 . Details have been given by Gordon \& Duguid (1970). 


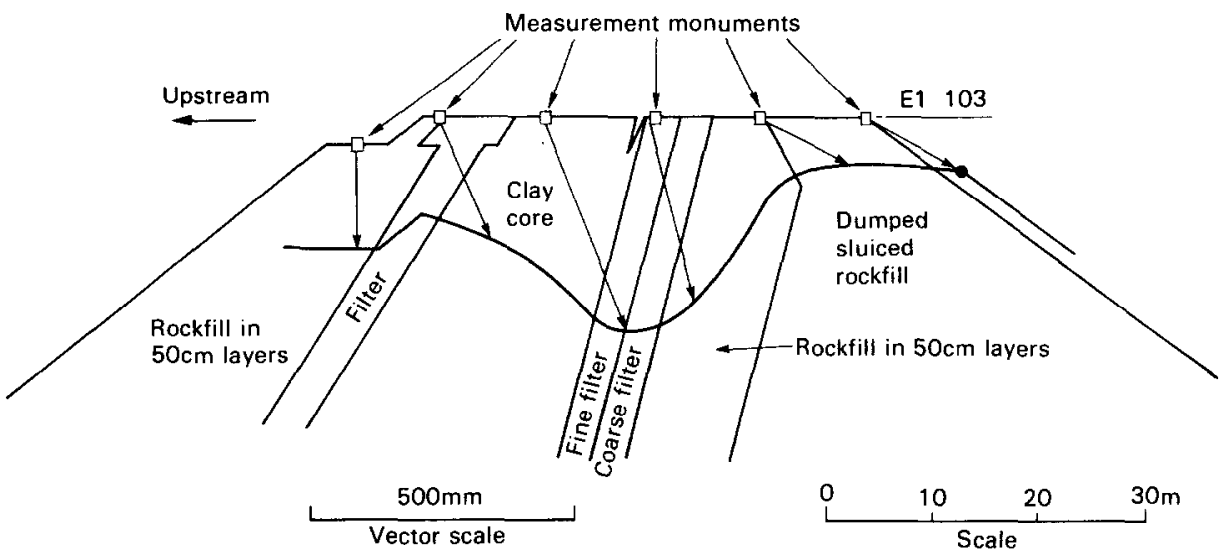

Fig. 14. Djatiluhur Dam: surface movements 10 January-13 April 1965

This experience illustrates construction deformations that, without halts in fill placement, would not have been observed. It is also evident that useful measurements of vertical and horizontal movements may be made on the surface of the fill during enforced rest periods such as winter shut-down.

Such an approach was used at Djatiluhur Dam $(100 \mathrm{~m})$ when longitudinal cracking was seen at the downstream edge of the core, in the construction surface, only $12 \mathrm{~m}$ below design crest level. Impounding had begun and the reservoir had recently exceeded the height of the coffer-dam, introducing water into the upstream rockfill.

Construction was stopped and six measuring stations placed across the surface as indicated by Fig. 14 (Sherard, 1973). Measurements of both vertical and horizontal movements made during the period 10 January-13 April 1965 confirmed that the upstream rockfill was settling more than the downstream shoulder and that the width was increasing. The measurements also showed that the clay core was settling more than the shoulders.

At Hyttejuvet $(93 \mathrm{~m})$ measurements made during the winter shut-down of 1964-65, when the dam was $44 \mathrm{~m}$ high, showed $8 \mathrm{~cm}$ settlement of the wet moraine core and no settlement of the supporting gravel fill.

These aspects will be discussed further in the section on total pressures and arching.

To obtain more information about the behaviour of puddled clay cores, the BRS developed two settlement gauges that were installed during 1957 in Selset Dam (37 m). A vertical plate gauge, consisting of vertical, telescopic plastic tubing with steel plates threaded over it, was installed at two positions on the core centre line. Because the puddled clay was placed by hand and compacted by foot, the tubing could be kept above fill level, supported by temporary frames. Plate levels were found by lowering an induction coil through the tubing.

To overcome problems with vertical tubes in machine-placed shoulder fill, a sealed water overflow settlement gauge was used, based on that of Spangler (1933). The buried unit was connected to an instrument house by three plastic tubes: one connecting the overflow to a transparent standpipe, one to balance the air pressure in the buried unit and one as a drain for overflowed water. These tubes were placed in trench through the fill. The mistake was made of using small, $2.5 \mathrm{~mm}$ bore tubing (piezometer tubing) for the water level. The air and drain tubes were $13 \mathrm{~mm}$ bore. The equilibrium time was so long that the level of the overflow was found by plotting the rate of fall in the standpipe and extending the straight line to zero rate. Equilibrium time is proportional to $d^{4}$, so by increasing the tube bore to $6 \mathrm{~mm}$, almost the largest size that can be cleared of air by flushing, the time was reduced to about one minute (depending on distance), making it practical to repeat readings to check behaviour and to improve accuracy. The same $6 \mathrm{~mm}$ bore tubing was used for the air balance: it had been found extremely difficult to remove water that had entered the $13 \mathrm{~mm}$ bore air tube. A description of the current apparatus was given by Penman, Charles, Nash \& Humphreys (1975).

Consolidation of the puddled clay was small during the time of construction as evident from the small settlements that occurred during the two winter shut-down periods. Measured settlements during active construction, however, were much greater than those of the adjoining fill, indicating a good deal of plastic flow and widening of the lower part of the core. This must have caused 


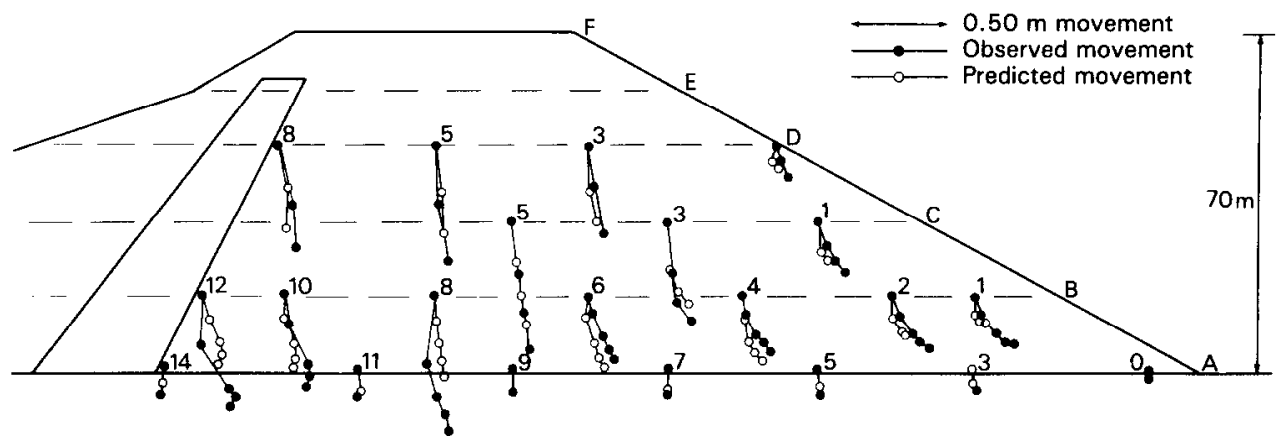

Fig. 15. Predicted and observed movements at Scammonden Dam

compression of the shoulder fill in the horizontal direction and horizontal movements may have extended to the toes.

\section{Horizontal movements}

To measure horizontal movements within the fill, the BRS developed the horizontal plate gauge and at the same time developed methods for predicting these movements. The'gauge, which used $70 \mathrm{~mm}$ dia. telescopic plastic tube, laid to a slight outward fall, passing through metal plates, was similar to that used in Gepatch Dam in Austria. The BRS gauge used a General Post Office duct motor to pull an induction coil and a water overflow unit into the tube so that both the horizontal and the vertical position of each plate could be measured. The tube was laid from instrument chambers built into the downstream slope and by measuring their position by precise surveying from stable reference pillars, built into the valley sides outside the zone of influence of the dam, the position of each plate could be measured in relation to these independent stable positions. An overall accuracy of $\pm 3 \mathrm{~mm}$ was obtained with this system.

First installation of these gauges was in Scammonden Dam (70 m) during 1967. The tube diameter was considered to be too large for it to be taken through the clay core so measurements were confined to the downstream shoulder which in this dam, because of a motorway on the crest and a sloping core, was particularly wide. Plates were placed at positions that could be used as nodes of a finite element grid, and the tubes terminated about $5 \mathrm{~m}$ inside the clay core, so that plates could be placed at the interfaces between core and filter, and filter and rockfill shoulder.

Predictions of movement were made by an analysis using finite elements and properties of the rockfill obtained with a large oedometer. The work was described by Penman, Burland \& Charles (1971) and results showing predicted and observed movements are given by Fig. 15 .
This work was repeated when Llyn Brianne $(90 \mathrm{~m})$ was constructed. At both dams, the downstream face of the cores moved downstream during construction, indicating that horizontal pressure from the clay exceeded that from the rockfill shoulders causing compression of the downstream shoulder, movement of the downstream slope and expansion of the core width.

\section{Movements caused by impounding}

The thrust in a downstream direction from water impounded in the reservoir $(4000 \mathrm{t} / \mathrm{m}$ length of dam over the central part of Llyn Brianne) was expected to cause some downstream movement. The fact that numerous dams have been designed with clay cores curved upstream in plan illustrates that the expectation was general. It was with some surprise, therefore, that it was found that there was no downstream movement of the measuring points on the downstream faces of the clay cores of both dams as the reservoirs rose to three-quarters of full height. The accuracy of the measurements was sufficient to show that after construction was complete the face of the core began to move slightly upstream owing to a reduction in the total pressure associated with dissipation of construction pore pressures. These small horizontal movements of the downstream face of the core continued during initial impounding.

To make a joint that will be watertight, as with a gasket between steel flanges, the total pressure normal to the joint must exceed the water pressure. At the interface between core and foundation, the normal total pressure must exceed the maximum water pressure that will be imposed by the reservoir: a principle which must apply to any potential surface passing through a clay core. The observed lack of downstream core movement on impounding was consistent with total pressures from the core, supported by the shoulders, that exceeded reservoir water pressure: a feature that could be regarded as essential for successful water 


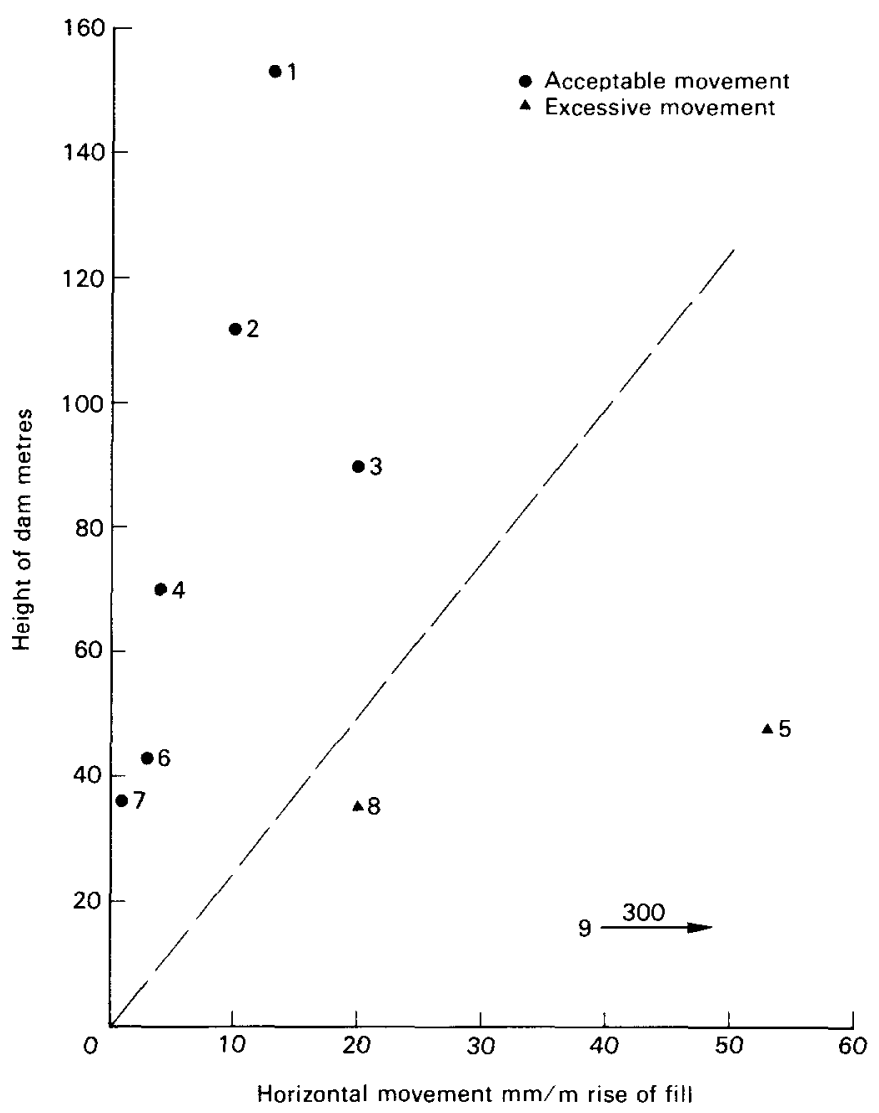

Fig. 16. Rates of horizontal movements observed during construction (dam details are given in Table 1)

retention. This prestressing by the core of the shoulders to pressures greater than those imposed by the reservoir water can also be regarded as a valuable feature in ensuring the adequacy of shoulders and foundations before impounding.

\section{Warning of failure}

The use of movement measurements to control construction and to warn of impending failure is not straightforward and depends on potential modes of failure, stiffnesses and brittleness of fill and foundation. Penman \& Charles (1974) published values of maximum rates of horizontal movements measured as millimetres per metre rise of fill that had been observed during construction of eight large dams. Two of these had suffered non-brittle shear failure and showed relatively large (unacceptable) horizontal movements that occurred slowly and stopped after fill placement had ceased. These rates have been plotted against the height of dam in Fig. 16. Details of the dams are given in Table 1.

Measurements of the horizontal movements of the upstream slope of Carsington were not begun until half-way through the second placing season (1983) after the toe berm had been built, and results are shown by Fig. 17. The maximum rate of movement observed during the remainder of that season was $20 \mathrm{~mm} / \mathrm{m}$ rise of fill and is shown in Fig. 16. Settlement of the fill surface was measured on five pegs across the major section during the last two-thirds of the winter shut-down period (Fig. 18). There was negligible apparent settlement of the downstream shoulder fill during the first eleven weeks of measurements, but $75 \mathrm{~mm}$ relative to the downstream shoulder in the middle of the clay core and a tilting settlement of 30 $45 \mathrm{~mm}$ in the upstream fill. Six weeks later, the central settlement had increased to $100 \mathrm{~mm}$, giving a clear indication of relative movement between core and downstream shoulder. $\Lambda$ constriction, then a blockage formed in the cross-arm gauge (see Fig. 18) at a position that was consistent with a potential slip surface through the core and core extension. At the same time, the piezometer CU1 ceased to operate. Its connecting tubes 
Table 1

\begin{tabular}{|c|c|c|c|c|c|}
\hline & Dam & Type & $\begin{array}{l}\text { Height: } \\
\mathrm{m}\end{array}$ & $\begin{array}{l}\text { Average } \\
\text { slope* }\end{array}$ & $\begin{array}{l}\text { Maximum rate of horizontal movement } \\
\text { measured: } \mathrm{mm} / \mathrm{m} \text { height of fill }\end{array}$ \\
\hline 1 & Gepatsch & $\begin{array}{l}\text { Rockfill with central } \\
\text { clay core }\end{array}$ & 153 & $1: 1 \cdot 5, \mathrm{~d}$ & 13 \\
\hline 2 & Blowering & $\begin{array}{l}\text { Rockfill with central } \\
\text { clay core }\end{array}$ & 112 & $1: 1 \cdot 9, \mathrm{~d}$ & 10 \\
\hline 3 & Llyn Brianne & $\begin{array}{l}\text { Rockfill with central } \\
\text { clay core }\end{array}$ & 90 & $1: 1 \cdot 75, \mathrm{~d}$ & 20 \\
\hline 4 & Scammonden & $\begin{array}{l}\text { Wide rockfill with } \\
\text { upstream sloping } \\
\text { clay core }\end{array}$ & 70 & $1: 1 \cdot 8, \mathrm{~d}$ & 4 \\
\hline 5 & Galisteo & Earthfill & 48 & $1: 3 \cdot 2, \mathrm{u}$ & 53 \\
\hline 6 & Backwater & Earthfill & 43 & $1: 3, \mathrm{~d}$ & 3 \\
\hline 7 & Derwent & $\begin{array}{l}\text { Earthfill with } \\
\text { clay core }\end{array}$ & 36 & $1 \cdot 2-1 \cdot 15, \mathrm{~d}$ & 1 \\
\hline 8 & Carsington & $\begin{array}{l}\text { Earthfill with } \\
\text { clay core }\end{array}$ & 35 & $1: 3, \mathrm{u}$ & 20 \\
\hline 9 & Muirhead & $\begin{array}{l}\text { Earthfill with } \\
\text { puddled clay core }\end{array}$ & 22 & $1: 3, \mathrm{u}$ & 330 \\
\hline
\end{tabular}

* d, downstream; u, upstream.

pass along a common trench with those from $\mathrm{CC} 1$ which continued to function, indicating damage to the tube in the stretch between the two piezometers.

During the winter shut-down, the horizontal movement of the toe was only about $25 \mathrm{~mm}$. This imbalance of observed movements is indicative of potential progressive failure.

No further measurements could be made on the five pegs when fill placement recommenced. The added weight of fill caused further measured horizontal movements. For comparison with other dams, these toe movements have been divided by the half-width of the dam at the level of the observations and these values are shown plotted against dam height in Fig. 19. This plot shows the acceleration of horizontal movement associated with impending slip failure. Examples are also given of observed movements of two rockfill dams.

The shape of stress-strain curves depends on the material and the type of test. In general, as failure is approached, small stress increases cause large strain increments (Fig. 20). Under a controlled rate of strain, a brittle clay can cxhibit considerable post-failure stress reduction, but under stress control, where the failure stress is maintained, post-failure strains are large and occur rapidly. The horizontal movements (strains) at Carsington followed this pattern.

With non-brittle materials, such as remoulded silty clay (boulder clay), post-peak strain rates may not be large and dam failure, e.g. Muirhead, may involve deformations that only continue until the dam shape has changed sufficiently to restore equilibrium: this may be assisted by pore pressure reduction caused by shearing dilation. Movement measurements, however, as shown in Fig. 19, can be used to indicate the approach of instability, even though subsequent movements may not be as alarming as with a brittle clay.

\section{Upstream membrane}

The use of an upstream membrane, by avoiding thrust from a clay core, should enable a much smaller section to be used for the dam. Unsatisfactory behaviour of dumped rockfill dams with upstream membranes had put this design out of favour, but the realization that stable rockfill required sufficient fines content to support each large piece of rock and to fill the spaces between the large pieces completely, to prevent rotation, has produced, in combination with compaction by vibrating rollers, some very satisfactory upstream membrane rockfill dams built since 1970, e.g. Foz do Areia $(160 \mathrm{~m})$, Salvajina $(148 \mathrm{~m})$, Alto Anchicaya $(140 \mathrm{~m})$, Khao Laem (130 m), Cethana (110 m). Penman (1971) and Penman \& Charles (1976) have discussed rockfill for dams and suggested that the amount of fines should be limited so that in situ $k>1 \times 10^{-3} \mathrm{~cm} / \mathrm{s}$ to avoid construction pore pressures. Such a value allows plenty of water to be used to improve workability in the knowledge that surplus can safely drain. If the permeability is lower, the fill should be regarded as earth rather than rockfill.

Winscar Dam $(50 \mathrm{~m})$ was the first in England to use an upstream asphaltic membrane (Collins \& Humphreys, 1974). The BRS fitted horizontal plate gauges passing right through to contact the 


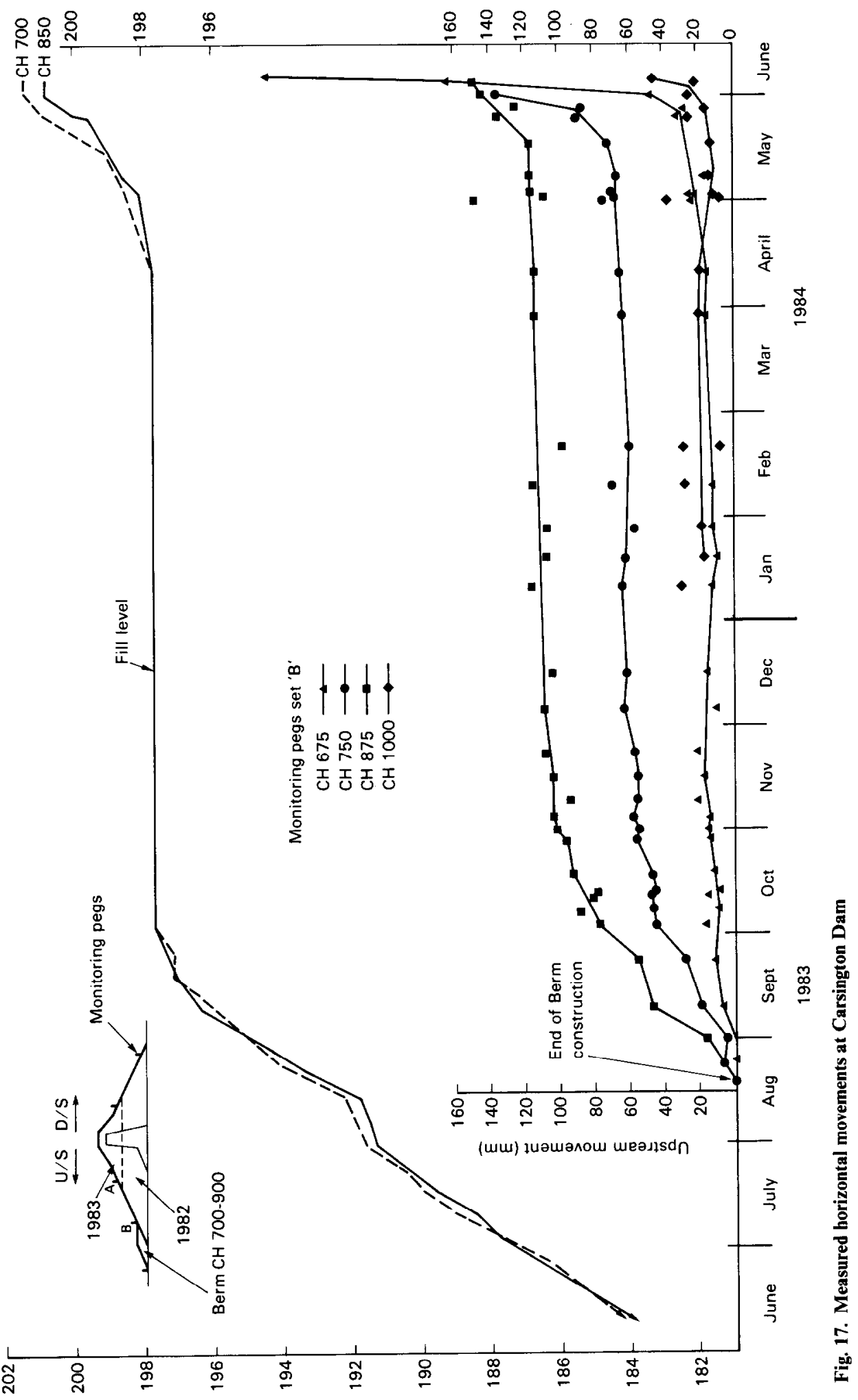



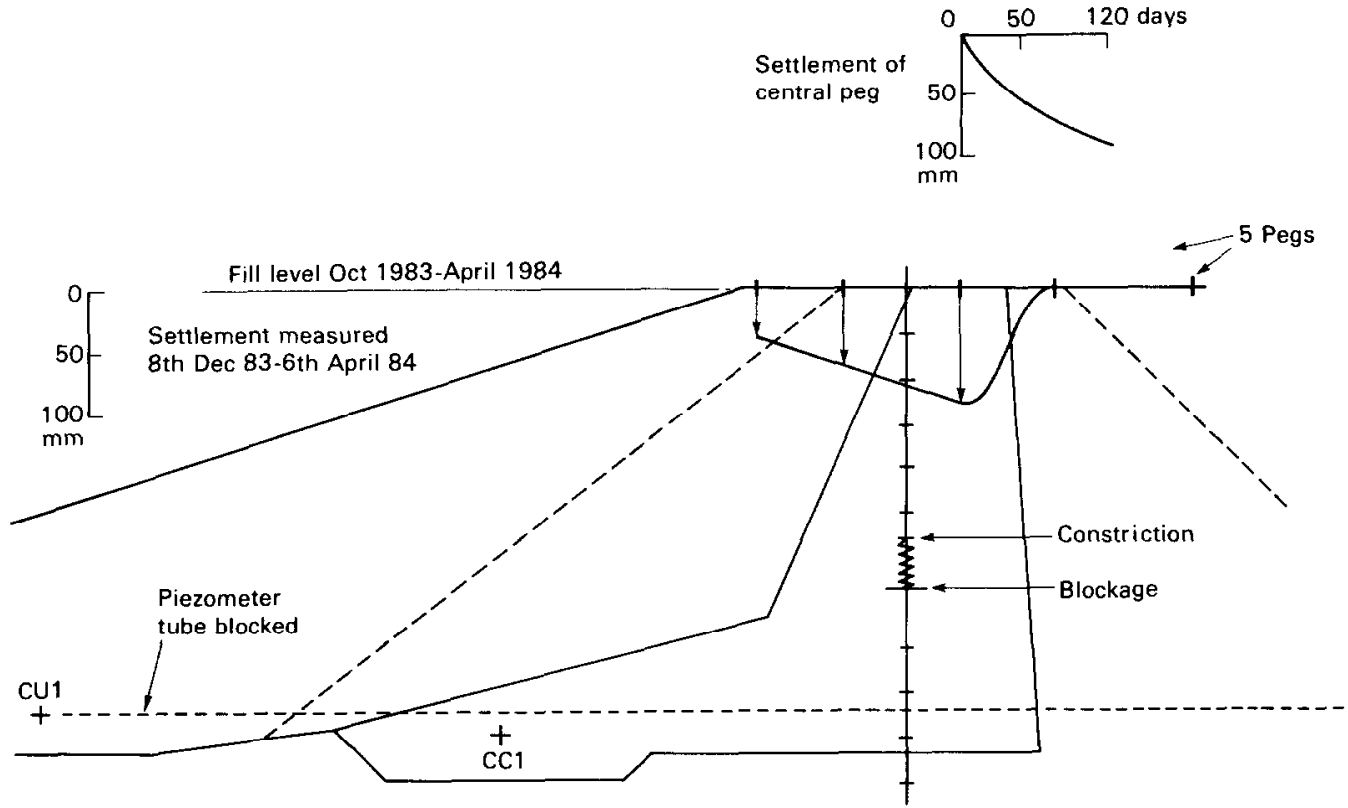

Fig. 18. Conditions at the end of the 1983-84 winter shut-down

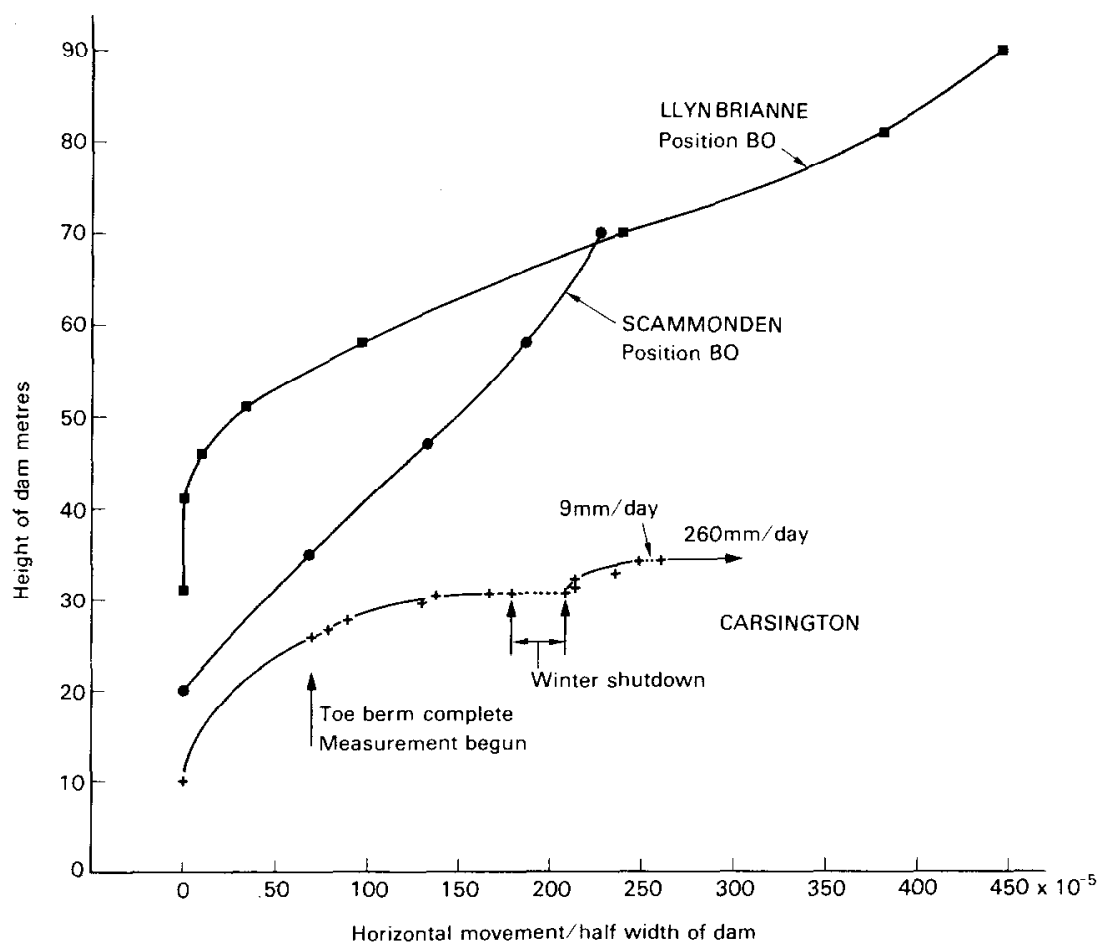

Fig. 19. Horizontal movements related to dam height 


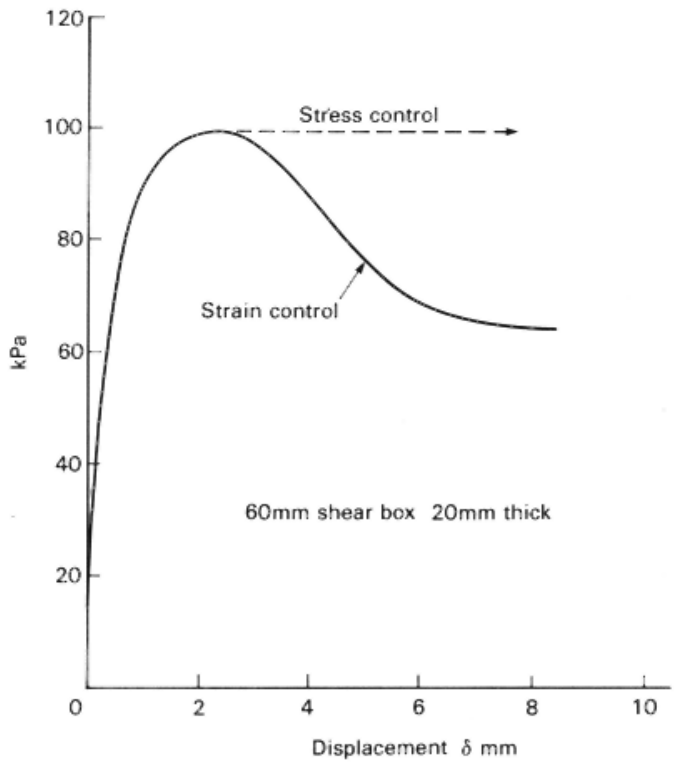

Fig. 20. Stress-strain curve for clay

underside of the membrane (Fig. 21) to observe not only movement of the sandstone rockfill but also to measure impounding deflexions. These deflexions were found to be less than given by a class A prediction made by Penman \& Charles (1975) as shown by Fig. 22. The reservoir did not reach full height on first filling and there were several reversals before top water level (TWL) was reached for the first time. It has been suggested by Penman \& Charles (1985a) that the smaller movements were due to a reduction in shear stress in the rockfill during impounding. During construction, the value of $\sigma_{1}{ }^{\prime} / \sigma_{3}{ }^{\prime}$ in large zones of the fill could be expected to remain sensibly constant, while the mean effective stress $\left(\sigma_{1}{ }^{\prime}+2 \sigma_{3}{ }^{\prime}\right) / 3$ increased, whereas the reservoir water pressure on the membrane would reduce $\sigma_{1}{ }^{\prime}-\sigma_{3}{ }^{\prime}$. Results from a triaxial test made to simulate these conditions are shown in the lower part of Fig. 22. The shear strain $\varepsilon_{1}-\varepsilon_{3}$ increased during the 'construction phase', but during 'impounding' there was negligible shear strain indicating a stiff condition. This approach was used to revise the predictions: the revised values, also shown by Fig. 22, are in much closer agreement with the observed deformations.

These membrane deflexion measurements were only made at the three levels of the horizontal plate gauges and at the crest. They were not able to measure local distortion at the connection between the membrane and the toe structure: a joint that is under maximum reservoir pressure.

To overcome this difficulty, deflexions of the
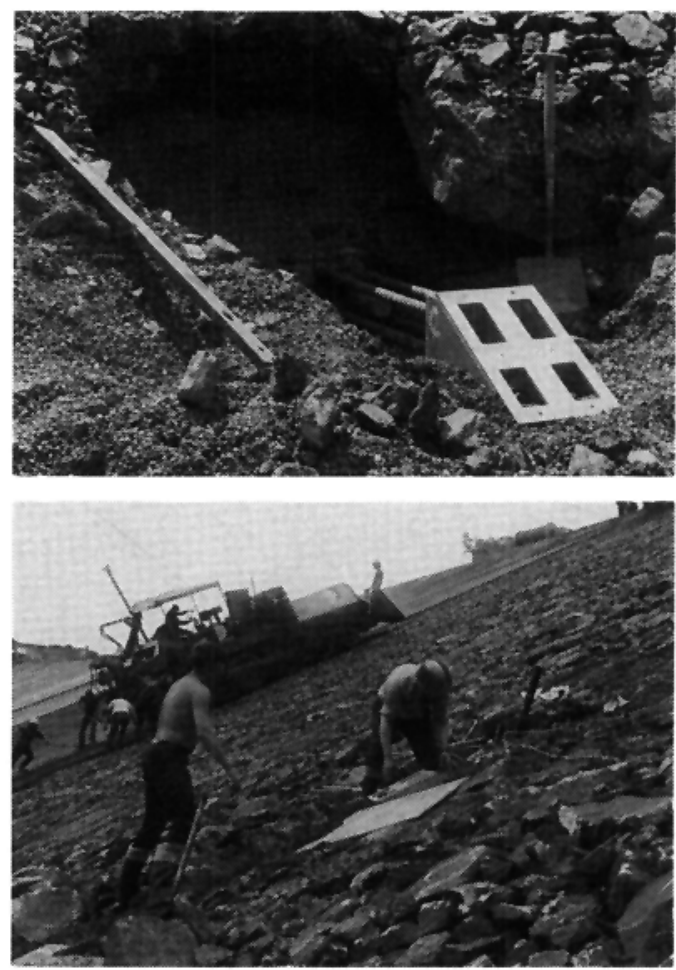

Fig. 21. Upstream end of a horizontal plate gauge

asphaltic membrane of Marchlyn Dam (72 m) were measured by the BRS with an inclinometer mounted in a trolley which could travel underwater from crest to toe on rails secured to the membrane (Penman \& Hussain, 1984). The concrete toe structure (Baines, Newman, Hannah, Douglas \& Carlyle, 1983) was cast into a shallow excavation to cut through slightly weathered bedrock and formed a cap to the grout curtain. It contained an inspection/drainage gallery and was shaped to accept the edge of the membrane and to provide a cushion for the inevitable differential movements. The structure was designed so that there was only about $2 \mathrm{~m}$ depth of rockfill immediately behind the wall, but in view of the $70 \mathrm{~m}$ head of water and the relative compressibilities of concrete $\left(13.5 \times 10^{6} \mathrm{kN} / \mathrm{m}^{2}\right)$ and the rockfill $\left(25 \times 10^{3} \mathrm{kN} / \mathrm{m}^{2}\right)$ several millimetres differential movement was expected. The amounts measured under full reservoir are given by Fig. 23.

There is a danger that unforeseen foundation conditions can lead to the use of undesirably high toe walls (Penman, 1982). There have been cases where the toe position was decided from the results of site investigation and the grout curtain constructed. Site stripping then revealed deeper than expected weathering, necessitating the use of 


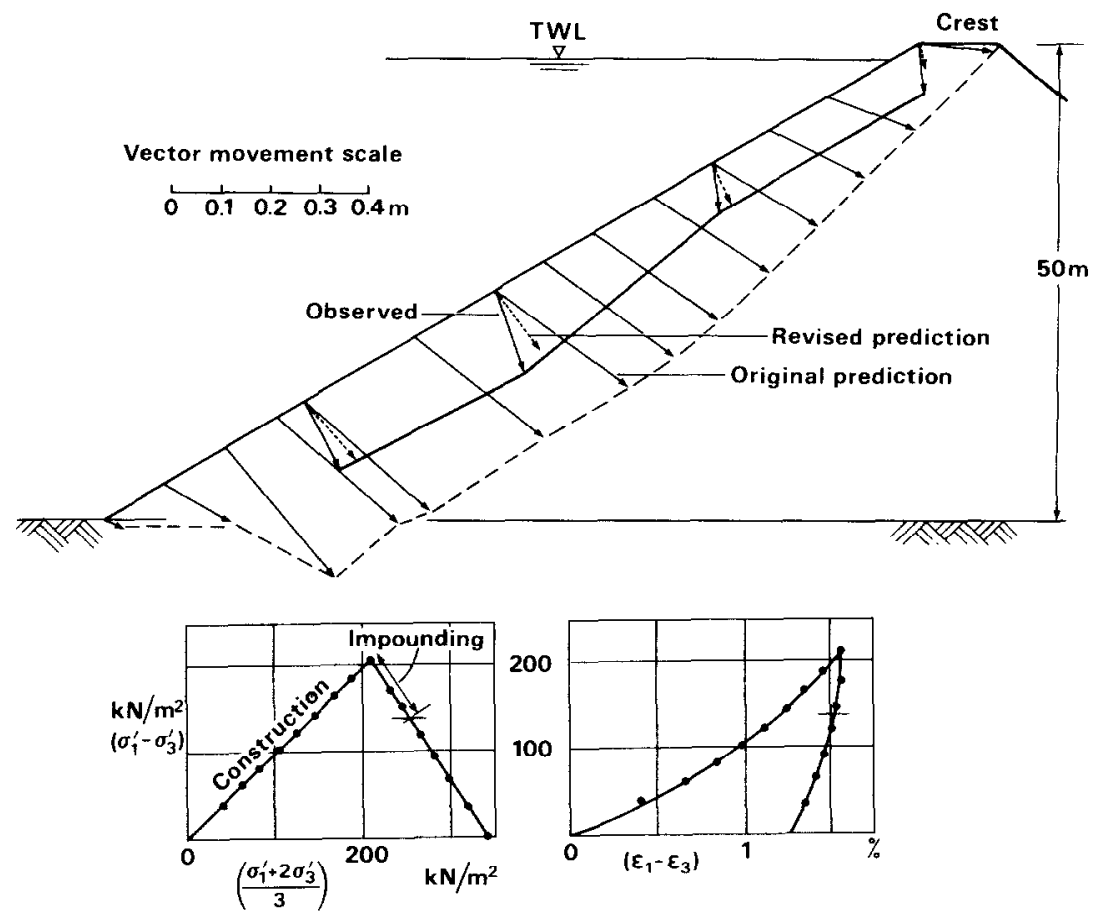

Fig. 22. Winscar Dam: movements during impounding and results from rockfill tests

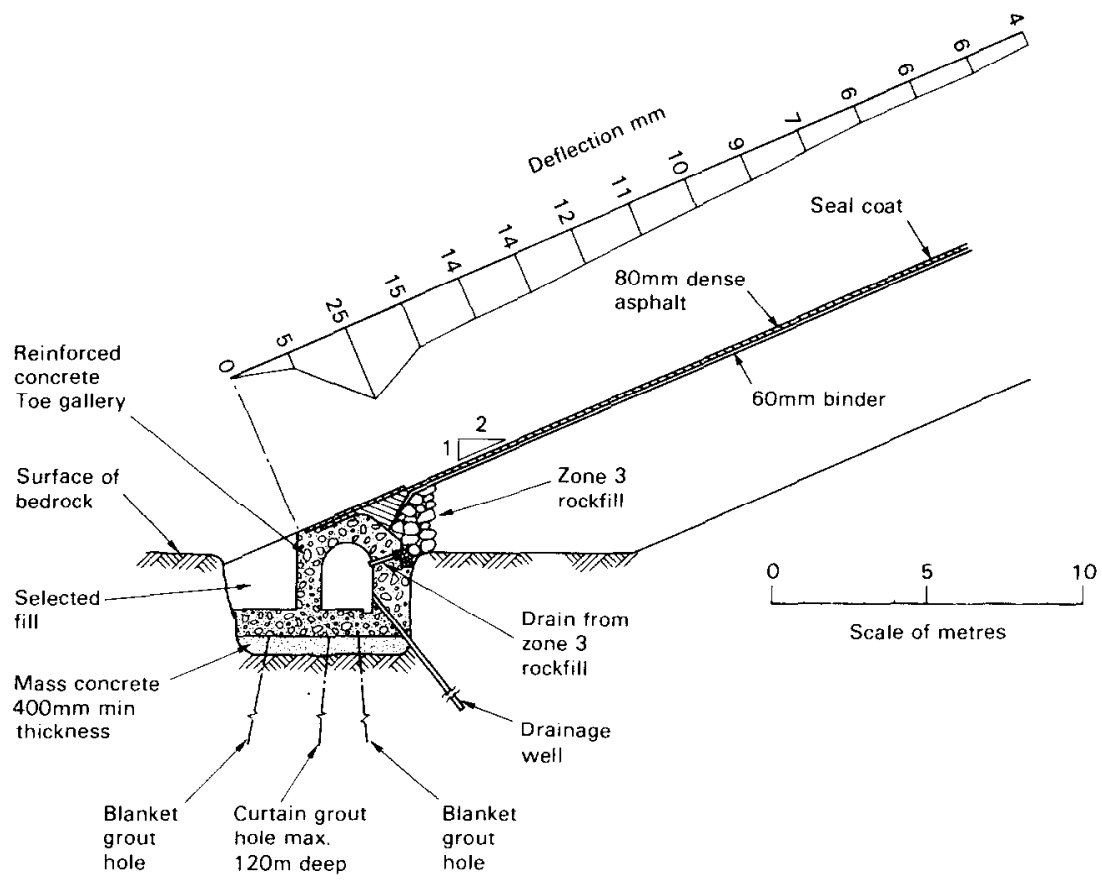

Upstream toe gallery

Fig. 23. Marchlyn Dam: membrane deflexion near the toe structure 


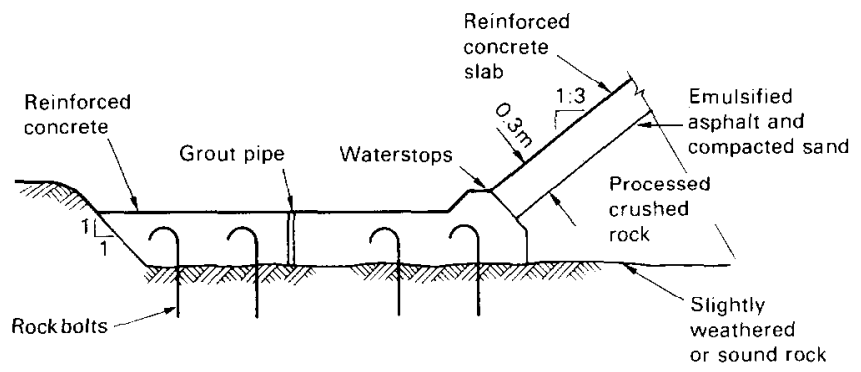

(a)

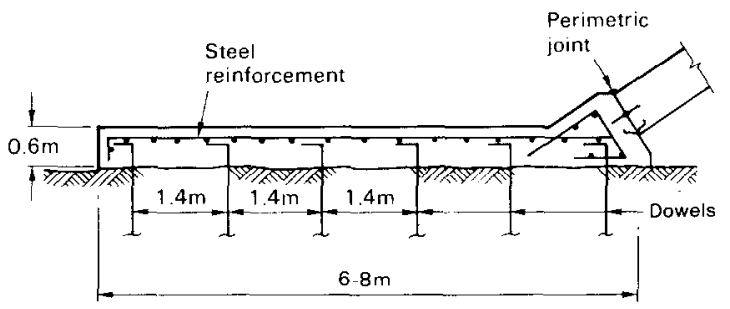

(b)

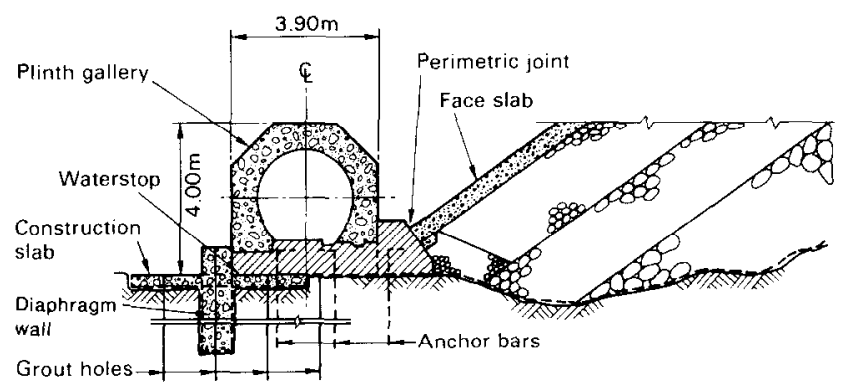

(c)

Fig. 24. Toe slabs of three concrete-faced rockfill dams: (a) Deer Creek;

(b) Salvajina; (c) Khao Laem

a wall over the curtain. Difficulty in obtaining good compaction behind the wall created an even more compressible zone and resulting deformations were enough to tear the membrane. Sherard (1985a) has also drawn attention to the danger from a high toe wall causing damage to the membrane.

There has been a move with reinforced concrete membrane dams to reduce the height of the toe structure to a minimum by use of a toe slab, as shown by Fig. 24. The design for Deer Creek $(85 \mathrm{~m})$ (Hollingsworth, Conner \& Anderson, $1985)$ and Salvajina $(148 \mathrm{~m})$, the second highest concrete-faced rockfill dam currently in service in the world (Sierra, Ramirez \& Hacelas, 1985) pro- vided fiat slabs tied down to the bedrock. At Khao Laem $(130 \mathrm{~m})$, founded on karst, the plinth slab was attached to a diaphragm wall and fitted with an inspection gallery placed over the slab so as not to introduce undesirable height (Watakeekul, Roberts \& Coles, 1985).

\section{Central asphaltic core}

At Megget $(55 \mathrm{~m})$, the first British dam to be built with a central vertical asphaltic core, it was hoped to see more clearly the effect of impounding on downstream movement. The shoulder fill was a well-graded gravel that readily developed a high density under vibrating rollers (site control density tests often indicated negative air voids!) 


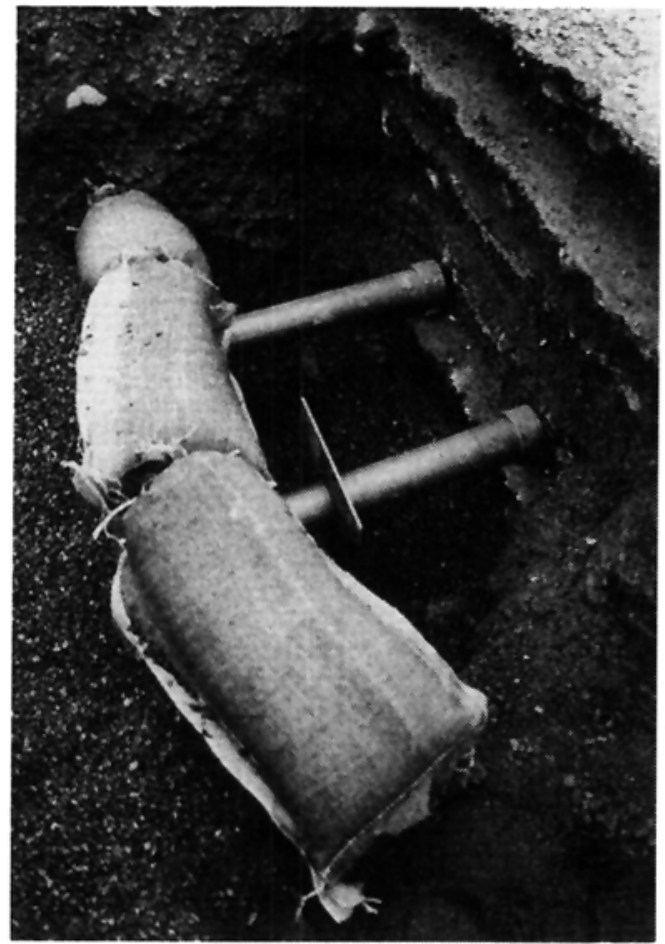

Fig. 25. End of a horizontal plate gauge to be connected to the asphaltic core with concrete

and as a result was very stiff. The horizontal plate gauges for this dam were modified by providing an induction coil sensing unit at each steel plate, connected by steel pipes to form a continuous string that remained inside the telescopic plastic tubes (Penman \& Charles, 1982). This removed the slight error caused by elastic stretch of the steel measuring tape used with the original version and gave an improved accuracy that proved necessary with the stiff fill.

As with the clay cores, the plate gauges were not taken through to the upstream side, but the last plate was encased in concrete abutted to the downstream face of the asphaltic core so that any movement could be detected (Fig. 25). Predictions obtained with an analysis using finite elements and oedometer results (Penman \& Charles, $1985 \mathrm{~b}$ ) were of negligible horizontal movements during construction. Observations agreed with this prediction (Fig. 26, plates A6, B5 and C4) and indicated that the asphaltic core did not exert a large lateral thrust on the shoulder fill.

During impounding, the core acted as a thin membrane and transmitted reservoir water pressure to the downstream fill, although the total pressure increase in the downstream direction was limited by the reduction in upstream fill pressure due to submergence. The resulting downstream movements were less than predicted possibly because of the reduction in shear stresses in the downstream fill under the action of increasing $\sigma_{3}$.

\section{Accuracy of measurement}

The improved horizontal plate gauge has enabled the horizontal position of plates in relation to a reference plate at the instrument chamber to be measured with an accuracy to $\pm 0.5 \mathrm{~mm}$. Use of this apparatus at Kotmale Dam $(90 \mathrm{~m})$ has been described by Gosschalk \& Kulasinghe (1985).

Movements of the instrument chambers and other positions on a dam have been related to stable reference stations built outside the stress influence of the dam itself by precise surveying. Three-dimensional triangulation with a halfsecond theodolite and/or trilateration with electronic distance measuring equipment with an accuracy to $2 \mathrm{ppm} \pm 0.5 \mathrm{~mm}$ have given measurements accurate to $\pm 2 \mathrm{~mm}$ when instruments and targets could be always mounted exactly. Reference stations must be stable structures embodying mounting plates to suit the instruments so that they can be replaced precisely. The use of portable tripods over reference marks at ground level does not lead to high degrees of accuracy.

Detailed layout planning is needed to ensure maximum possible angular and/or distance changes from the expected movements and to be sure that sight-lines will not become obstructed during construction.

In general, bending of theodolite sight-lines can be reduced by keeping them well above the ground surface. Distance measurements are less affected by low level sight-lines. Theodolites with a built-in horizon produced by reflecting light from a liquid surface in practice give more accurate vertical angle readings than those with a separate bubble. Early construction of the reference stations can be of help in setting-out for the dam.

Repeat zero readings should be taken to establish the shape of the survey layout and the position of every new monument built on the dam. A suitable computer program is required to reduce instrument readings to co-ordinates of the observed positions.

\section{TOTAL PRESSURES AND ARCHING}

Although there had been concern that the use of different types of fill in the various zones of a dam would cause differential settlements and undesirable internal stresses, an observation of actual conditions could not be made until satis- 


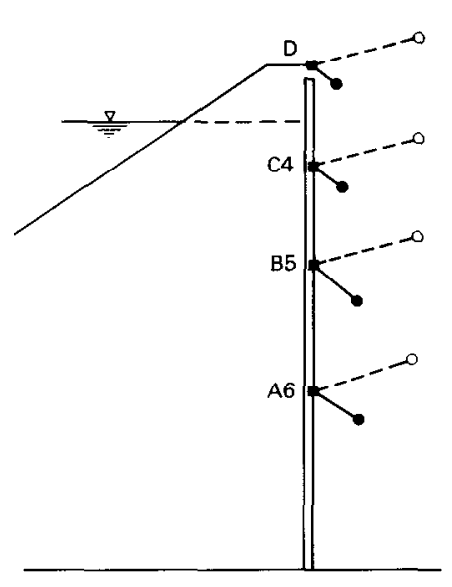

Movement during impounding
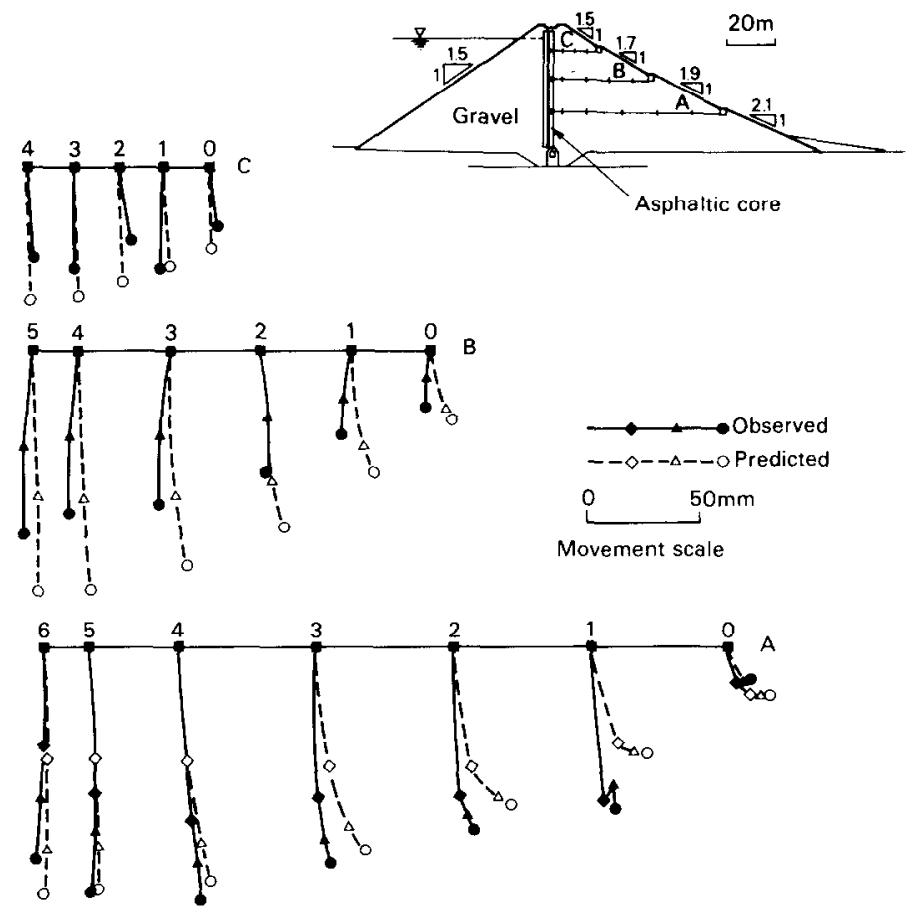

$\left\{\begin{array}{l}\text { Fill at level B } \\ \text { Fill at level C } \\ \text { Fill at crest level }\end{array}\right\}$

Movement during construction

Fig. 26. Megget Dam: movements during construction and impounding

factory earth pressure cells had evolved. To be ideal, a buried cell should have the same deformation characteristics as the element of fill it replaces. In practice a thin, stifl cell may give satisfactory measurements: installation details are more likely to cause irregularities.

A research programme on distribution of total pressures was begun in 1940 by the US Corps of Engineers. The Waterways Experimental Station developed a relatively thin cell that was less compressible than most fills. Load was transmitted through oil to a central diaphragm fitted with stuck-on resistance strain gauges. It was $610 \mathrm{~mm}$ dia. $\times 25 \mathrm{~mm}$ thick, described in Waterways Experimental Station report (1942).

A line of 20 of these cells was placed to measure vertical pressures from upstream to downstream of the John Martin Dam (36 m) during the winter 1941-42, as shown by Fig. 27 . The results showed a pronounced arching action across the dam section. $\sigma_{\mathrm{v}}$ averaged $0 \cdot 36 \sigma_{0}$ in the wide core, whereas in the adjacent shoulders $\sigma_{\mathrm{v}}=1.37 \sigma_{0}$.

Taylor (1947) in his review of these results considered that the observed pressures, particularly those in the core, were too low to be reasonable. There had been a blizzard during installation and, although the greatest care was taken to exclude frozen backfill, it was felt that it might be more compressible than adjoining fill.

The summation of all the measured pressures was less than the overburden and Taylor suggested that the ratio of observed to true vertical pressure was 0.5 in the core and 0.7 in the shoulders. Even with these corrections (shown in Fig. 27), the arching action across the section remains clear and illustrates the marked reduction in vertical total pressure that can occur even in a wide core.

Taylor was not critical of the compressibility of the cells: he felt that the low measured pressures were due to pocketing action and emphasized the 


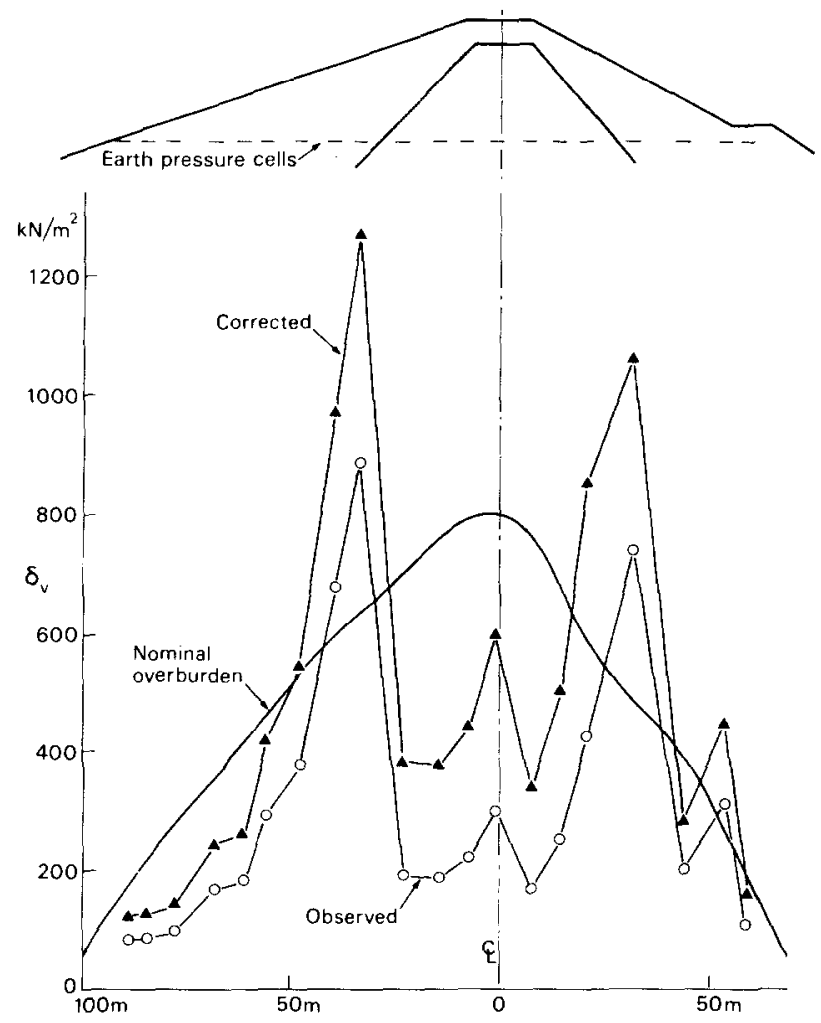

Fig. 27. Total pressures: John Martin Dam

importance of placing procedures. The working life of the cells, however, was less than two years.

\section{Narrow cores}

At about the same time, the Swedish State Power Board developed an oil-filled cell, connected by a small brass tube to a pressure gauge in an instrument house. It was criticized for acting as a thermometer, but in practice, once buried in fill, it remained at almost constant temperature. It was $270 \mathrm{~mm}$ dia. $\times 20 \mathrm{~mm}$ thick, described by Magnusson (1948) and included in the instrumentation of Medskogsforsen Dam (28 m) constructed during 1942-44.

The settlement of some narrow cores had been found to be less than expected from consolidation under $\sigma_{0}$ and it was feared that this could indicate horizontal cracks through the cores. To ensure watertightness, 'during the first years preceding consolidation of the fill' (Löfquist, 1951a), it became the practice to provide a thin reinforced concrete wall on the downstream side of the moraine cores.

Groups of the hydraulic cells, orientated to measure $\sigma_{\mathrm{v}}, \sigma_{\mathrm{a}}$ and $\sigma_{\mathrm{h}}$, were placed in the 3-4 m wide clay core of Harspranget $(50 \mathrm{~m})$ : measured pressures at the end of the second placing season are shown in Fig. 28. The $0.4 \mathrm{~m}$ thick concrete wall had been 'lubricated" with a $1 \mathrm{~mm}$ coating of bitumen and the clay, placed in $0.1-0.2 \mathrm{~m}$ layers, was compacted by tractors, producing $\gamma=21.9 \mathrm{kN} / \mathrm{m}^{3}$. Placement $w-12-14 \%$ and $k=3-30 \times 10^{-8} \mathrm{~cm} / \mathrm{s}$. In general the lowest stress was $\sigma_{\mathrm{a}}$ (in the direction along the dam axis), not $\sigma_{\mathrm{h}}$, and $\sigma_{\mathrm{v}}$ was less than $\sigma_{\mathrm{o}} / 2$ over much of the height.

In discussing these results, Löfquist (1951b) commented that arching might give rise to a risk of horizontal cracks in the core. When discussing Trollope (1957) he went further by stating that arching may take place in the longitudinal as well as the transverse direction of a dam and that, if $\sigma_{\mathrm{v}}$ decreased to a value lower than the pressure of water from the reservoir at the same level, the situation might be considered as detrimental to the watertightness of an earth core (Löfquist, 1957). It was almost ten years before hydraulic fracture was recognized as the cause of leakage at Hyttjuvet Dam.

\section{Silo action}

The narrow puddled clay core of Selset Dam was typical of British practice and an estimate of 

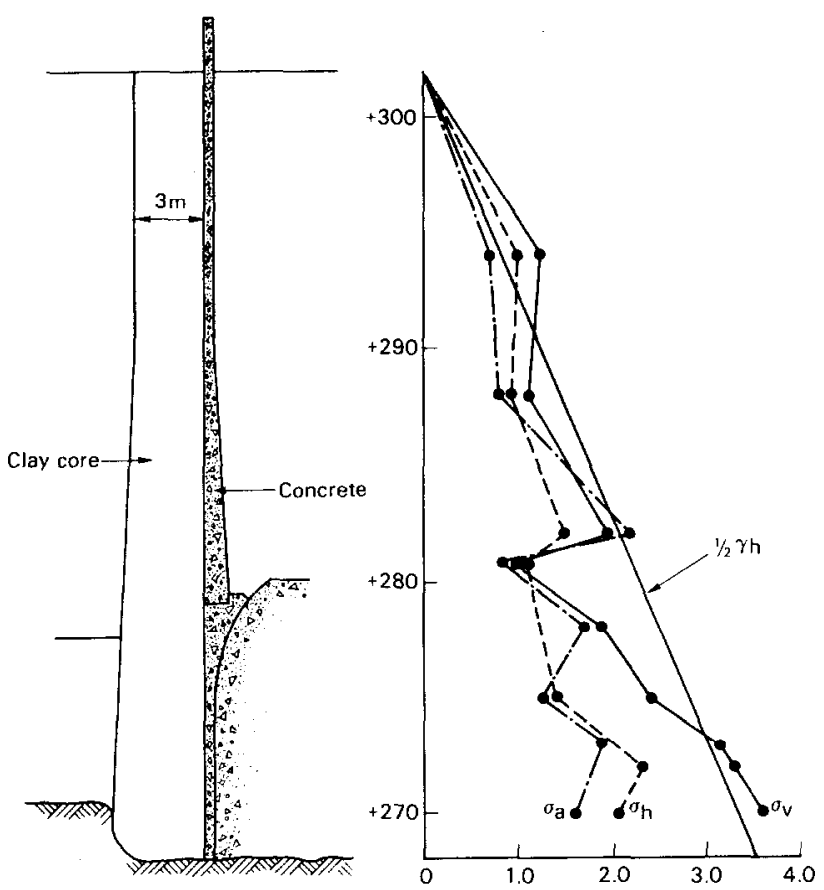

Fig. 28. Total pressures in the core of Harspranget Dam

the vertical total stress could be obtained by considering the core to be supported on either side by vertical walls to which it adhered perfectly. The settlement gauges had shown differential movements of more than $0.4 \mathrm{~m}$ between the core and shoulders, sufficient to mobilize the maximum $c_{u}$ of the puddled clay.

$$
\sigma_{\mathrm{v}}=h\left(\gamma-\frac{c_{\mathrm{u}}}{a}\right)
$$

where $h$ represents the height of core above the considered position, $2 a$ is the core width and $\gamma$ is the bulk density (more detailed analyses have been given by Bishop (1952), Anagnosti (1965) and Blight (1973)).

Total pressure cells were not placed in the core, but Bishop \& Vaughan (1962) compared calculated values of $\sigma_{v}$ with measured $u$. If in the wet, soft clay $u=\sigma_{\mathrm{v}}$, then good agreement was reached when $c_{\mathrm{u}}=15.8 \mathrm{kN} / \mathrm{m}^{2}$, an average value for the upper part of the core. Overburden and pore pressures are shown by Fig. 29 .

To avoid hydraulic fracture, the total pressure on any plane passing through the core must exceed the reservoir water pressure. The total pressure in the direction of the dam axis is given by

$$
\sigma_{\mathrm{a}}=K_{0}\left(\sigma_{\mathrm{v}}-u\right)+u
$$

In the case where $u=\sigma_{\mathrm{y}}$ then $\sigma_{\mathrm{a}}=\sigma_{\mathrm{y}}$ and if $u>$ $\gamma_{w} h$, where $h$ is the hcight of rescrvoir water over the position considered, then the condition is satisfied that $\sigma_{\mathrm{a}}>\gamma_{\mathrm{w}} h$.

Thus, if end of construction pore pressures, expressed in terms of a head of water, remain above the TWL during impounding, the risk of hydraulic fracture should be considerably reduced, a conclusion reached by Penman \& Charles (1979).

An earth pressure cell $280 \mathrm{~mm}$ dia. $\times 38 \mathrm{~mm}$ thick, developed at the BRS (Thomas \& Ward, 1969) used vibrating wire sensing units to measure the deflexion of stiff diaphragms on both faces. A group of five was placed at about quarter height on the centre line of the rolled clay coreone of the first in Britain - of Balderhead Dam $(48 \mathrm{~m})$ (Fig. 30$)$. To avoid pocketing, they were very carefully installed on prepared surfaces in a wide, shallow excavation and orientated to measure $\sigma_{\mathrm{v}}, \sigma_{\mathrm{a}}$ and $\sigma_{\mathrm{h}}$ as wcll as in two directions at $45^{\circ}$ to vertical in an upstream-downstream direction. The cells were unique in that they could measure pressure independently on their two faces. It was found that the face (generally upper) against which fill was compacted gave a higher reading than that placed on the prepared flat surface. This was attributed to slight bedding errors. Results at end of construction and after 

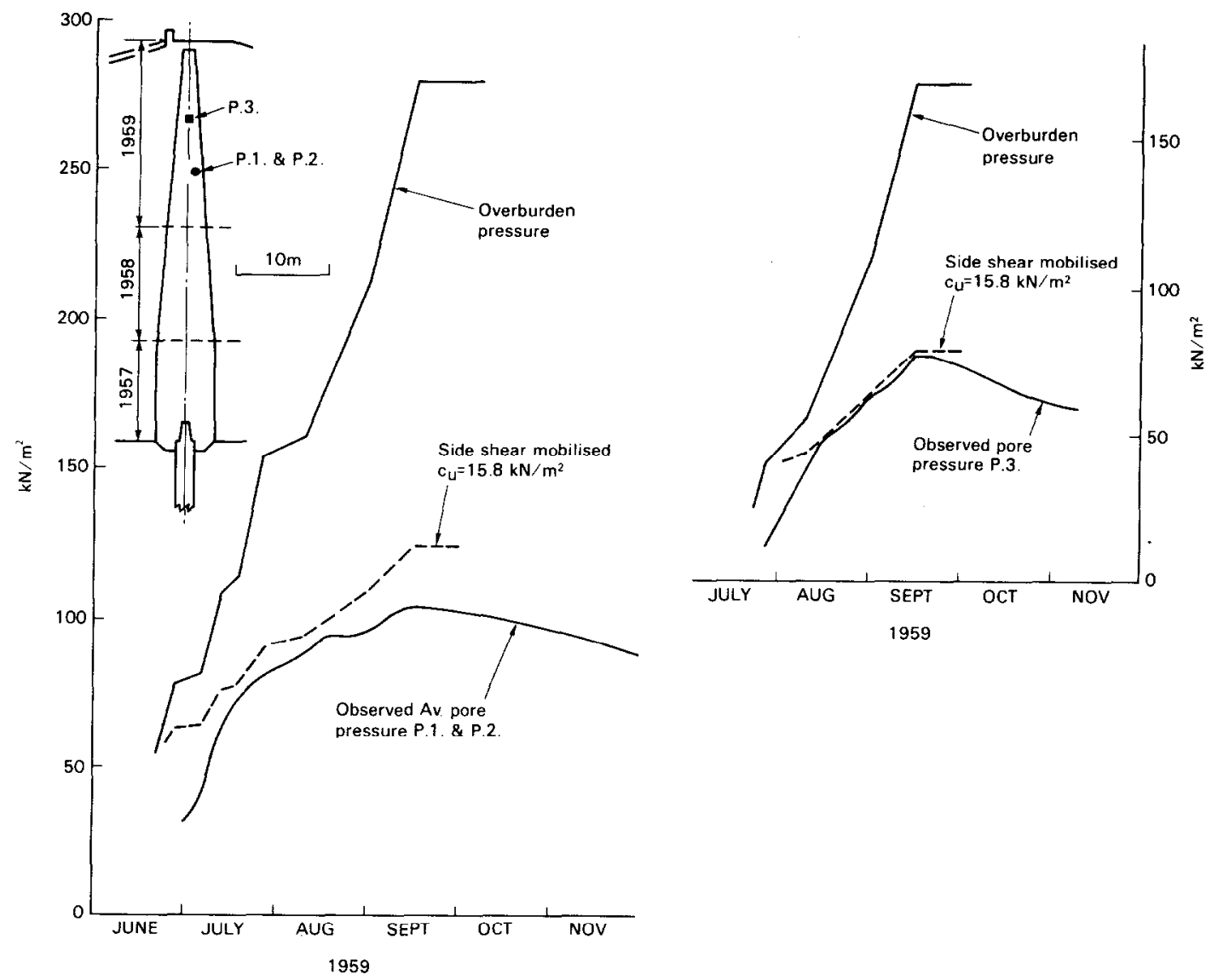

Fig. 29. Arching action and pore pressures in Selset core

impounding and partial drawdown are given in Table 2.

The boulder clay used for the core had $w<$ $w_{\mathrm{opt}}$ and was easy to place by machine. During the first season, when the earth pressure (EP) cells were placed, a combination of watering and rainfall increased $w$ to about the specified range of $w_{\mathrm{opt}}+1-3 \%$. Because of variations in $w_{\mathrm{opt}}$, the specification was changed to $w_{p}-3 \%$ to give a condition equivalent to $\omega_{\mathrm{opt}}-1 \%$, related to a property that was easier to measure. Strength specification had not been put into practice at that time.

The rate of increase of construction pore pressure $\delta u=0.5-0.7 \delta \sigma_{0}$ in this first season's fill. The second season's fill was somewhat drier and in the upper part $\delta u=0 \cdot 15-0 \cdot 2 \delta \sigma_{0}$. Measured values of $u$ and reservoir pressure in the upper part of the core are given in Table 3 .

At the end of construction, the lowest measured total pressure $\sigma_{\mathrm{h}}$ exceeded the water pressure from a full reservoir, and pore pressures measured by a piezometer associated with the pressure cells (C4) equalled the reservoir pressure, a situation which would avoid hydraulic fracture. Unfortunately, pore pressures in the upper part of the core at the end of construction were much lower.

\section{Hydraulic fracture}

Just before the reservoir became full for the first time in 1966 (Vaughan, Kluth, Leonard \& Pradoura, 1970), there was a marked increase in seepage and early in 1967 small depressions were found in the crest. A few months later, a sink hole $3 \mathrm{~m}$ wide and $2.5 \mathrm{~m}$ deep formed over the upstream edge of the core and the underdrain flow was found to be cloudy. Lowcring the reservoir had a disproportionate effect of rapidly reducing seepage and returning it to a clear condition.

The detailed study that ensued established this as the first recognized British example of hydraulic fracture by reservoir water pressure to cause leakage and erosion of a clay core. Flight auger holes $(0.4 \mathrm{~m}$ dia.) drilled dry through the crest 


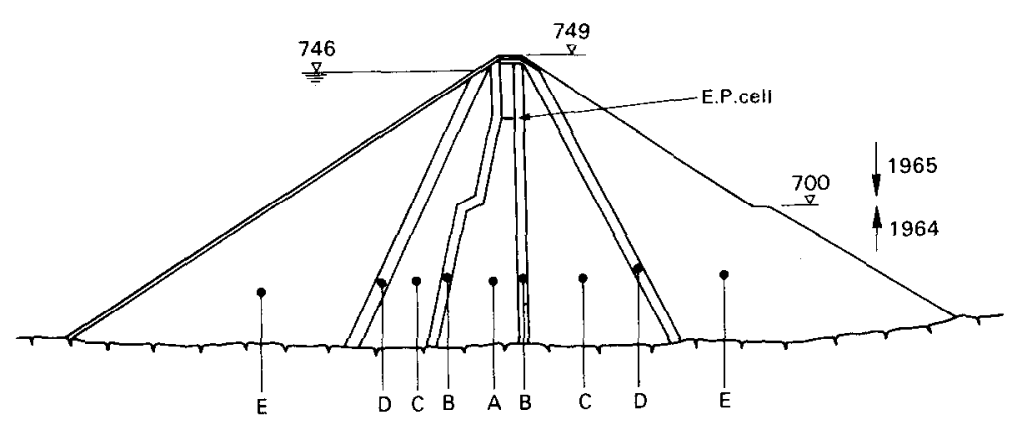

(a)

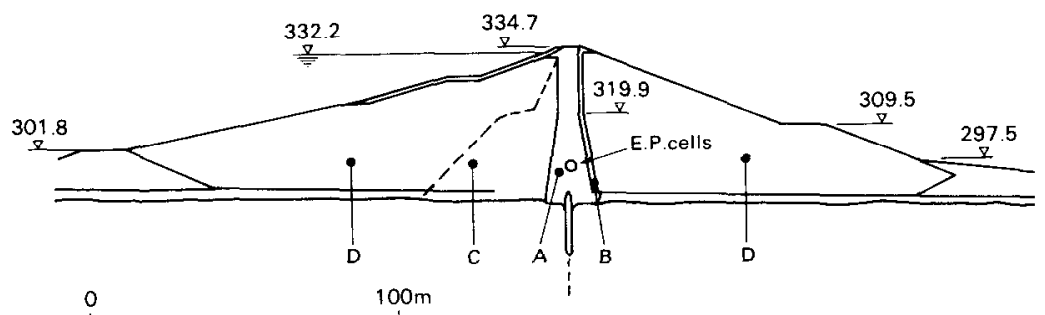

(b)

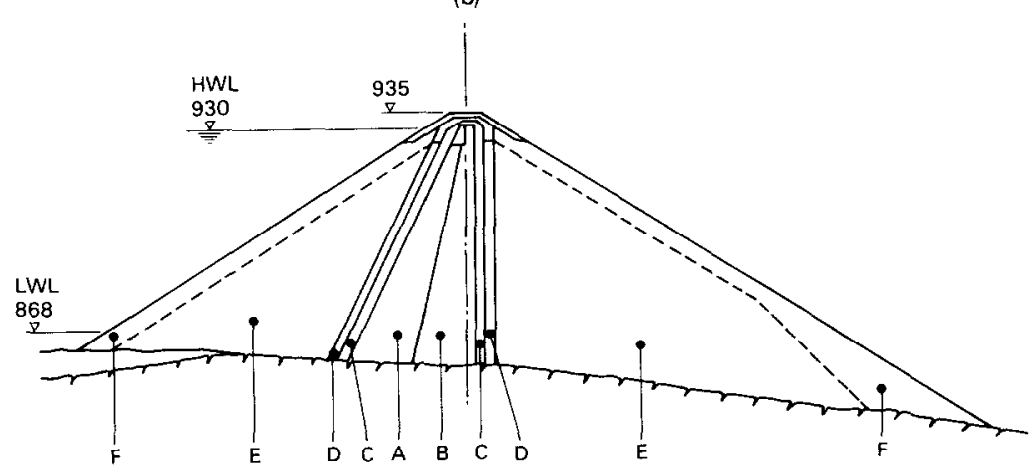

(c)

Fig. 30. Major sections of three dams: (a) IIyttejuvet (A, moraine; B, sandy gravel; C, gravel; D, tunnel spoil; $E$, quarried rock); (b) Balderhead (A, boulder clay; B, crushed limestone; $C$, fine shale; D, shale); (c) Viddalsvatn (A, screened moraine; B, unscreened moraine; C, screened tunnel spoil; $D$, unscreened tunnel spoil; $E$, tunnel spoil and quarry run; $F$, quarry run)

encountered soft clay and water that rapidly rose to reservoir level, at a depth of $14 \mathrm{~m}$. It was thought at the time that this position of the hydraulic fracture might relate to core shape. Core width was designed to be one-third height with a minimum of $6 \mathrm{~m}$ at the crest. Because of a shortage of suitable clay, instead of the usual uniform decrease in width from base to crest, the top $18 \mathrm{~m}$ of core was made $6 \mathrm{~m}$ wide with vertical sides (Fig. 30).

In Norway there had been a similar experience with Hyttjuvet Dam (Kjaernsli \& Torblaa, 1968) at about the same time as Balderhead, and with
Viddalsvatn (Vestad, 1976) a few years later. Moraine was used for the rolled, central cores of both dams.

At Hyttjuvet $(93 \mathrm{~m})$ high construction pore pressures measured in the core after the end of the first placing season, when the dam was at about half-height, caused a design change to make the corc much narrower in the upper half, to accelerate drainage. The resulting core shape (Fig. 30) had vertical sides for the upper part, similar to Balderhead. An earth pressure cell was placed $21 \mathrm{~m}$ below crest to measure the vertical pressure. Measured values are given in Table 4. 
Table 2. Balderhead core: pressures at cell cluster, $37.9 \mathrm{~m}$ below crest*

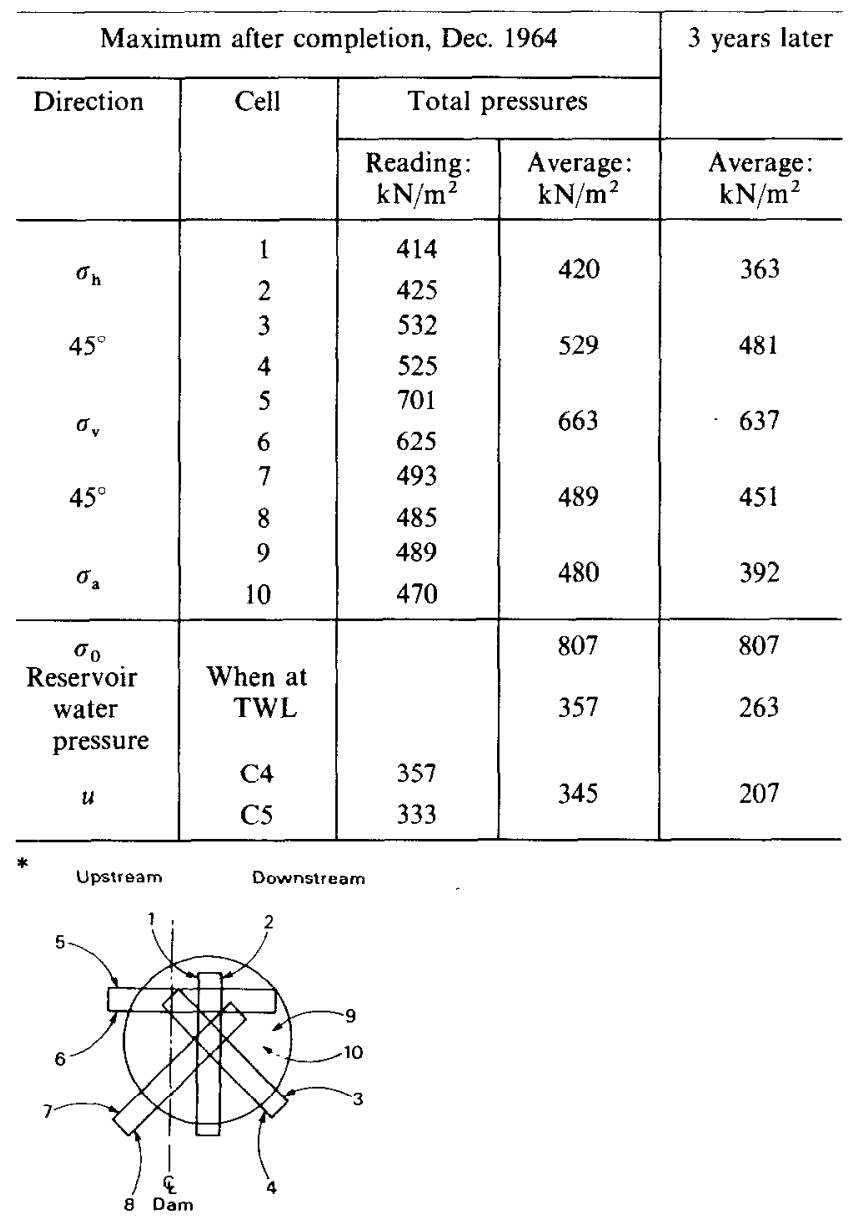

Table 3. Balderhead core: pore pressures in the upper part at the end of construction December 1964

\begin{tabular}{l|c|c|c|c}
\hline Tip & $\begin{array}{c}\text { Depth below } \\
\text { crest: } \mathrm{m}\end{array}$ & $u: \mathrm{kN} / \mathrm{m}^{2}$ & $\begin{array}{c}\text { Reservoir water } \\
\text { pressure when } \\
\text { at TWL: } \\
\mathrm{kN} / \mathrm{m}^{2}\end{array}$ & $\begin{array}{c}\text { Difference: } \\
\mathrm{kN} / \mathrm{m}^{2}\end{array}$ \\
\hline C13 & $6 \cdot 2$ & -13 & 41 & -54 \\
C12 & $9 \cdot 9$ & 29 & 78 & -49 \\
C9 & $21 \cdot 2$ & 32 & 191 & -159 \\
C7 & $27 \cdot 4$ & 73 & 253 & -180 \\
C8 & $27 \cdot 6$ & 66 & 255 & -189 \\
\hline
\end{tabular}

As with Balderhead, instrument measurements indicated arching in three ways

(a) $\sigma_{\mathrm{v}}<\sigma_{0}$

(b) $\delta u<\delta \sigma_{0}$

(c) core settlements were less than expected from laboratory consolidation tests.
Also, post-construction crest settlements were remarkably uniform, not reflecting valley shape. This suggested that settlement was occurring only in the upper few metres of core.

Measured leakage increased from $1-2 \mathrm{l} / \mathrm{s}$ to $60 \mathrm{l} / \mathrm{s}$ as the reservoir level rose from $7 \mathrm{~m}$ to $5 \mathrm{~m}$ of TWL on first filling. Before lowering could 
Table 4. Hyttejuvet core: pressures at a cell $21 \mathrm{~m}$ below the crest

\begin{tabular}{l|c|c|c|c}
\hline & $\sigma_{\mathrm{v}}: \mathrm{kN} / \mathrm{m}^{2}$ & $\begin{array}{c}\text { Reservoir } \\
\text { pressure: } \\
\mathrm{kN} / \mathrm{m}^{2}\end{array}$ & $\sigma_{0}: \mathrm{kN} / \mathrm{m}^{2}$ & $u: \mathrm{kN} / \mathrm{m}^{2}$ \\
\hline End of construction, Nov. 1965 & 174 & 0 & 460 & 165 \\
Reservoir 60\% full height, June 1966 & 128 & 0 & 460 & 145 \\
Reservoir full, Oct. 1966 & 226 & 170 & 460 & 225 \\
\hline
\end{tabular}

begin, the rate decreased to about $40 \mathrm{l} / \mathrm{s}$ by a selfhealing process. It did not return to the $1-2 \mathrm{l} / \mathrm{s}$ values until the reservoir had been lowered $29 \mathrm{~m}$ below TWL. $420 \mathrm{~m}^{3}$ of grout were injected into the upper $30 \mathrm{~m}$ of core. After seven yearly cycles of filling and emptying over a range of about $70 \mathrm{~m}$, a crater of $13 \mathrm{~m}^{3}$ volume, about $3 \mathrm{~m}$ wide, appeared in the crest over the upstream edge of the core. Probing and boreholes showed the fill to be very loose below the crater and it was regarded simply as a surface manifestation of loss of material in the seepage water over a long period. No change was observed in the small, clear seepage at the time when the crater appeared.

Leakage at Viddalsvatn $(75 \mathrm{~m})$ also occurred towards the end of first filling, as the reservoir rose over the last $5 \mathrm{~m}$ almost to TWL in 1972. Concentrated leaks of dirty water emerged abruptly several times at the downstream toe, with short duration flows of $60-140 \mathrm{l} / \mathrm{s}$. During second filling in 1973, as the reservoir reached TWL, leakage increased from less than $10 \mathrm{l} / \mathrm{s}$ to $98 \mathrm{l} / \mathrm{s}$ in four days, decreased to $63 \mathrm{l} / \mathrm{s}$ over the next two days then suddenly reached a peak of $210 \mathrm{l} / \mathrm{s}$. This decreased to $35 \mathrm{l} / \mathrm{s}$ as the reservoir was lowered $1 \mathrm{~m}$ during the following week.

Leak positions were determined by releasing a tracer at a depth of 4-5 $\mathrm{m}$ from a boat moving slowly along while seepage flow was at its maximum. Two positions found were confirmed later when craters appeared in the crest.

The rapid variations in flow rate indicate that after the moraine had fractured under reservoir pressure the sides or roof of the fissures collapsed, causing temporary blockage, a phenomenon not observed in a clay core.

Established lcakage positions along the lengths of the three dams (Fig. 31) lay over some feature of the valley shape that could have induced tensile strains by the 'beam bending' concept of Lowe (1970). This indicates that, although the cross-sectional shape and stiffness of the cores could account for arching, leading to hydraulic fracture, the positions where failure occurred probably suffered further reduction of total stresses due to longitudinal strain. This was not verified by instrumentation.

The failure of Teton $(93 \mathrm{~m})$ in 1976 on first filling of the reservoir (Fig. 3) may have been initiated by hydraulic fracture. The failure and subsequent investigation have been described in three detailed reports (Independent Panel, 1976; Interior Review Group, 1977, 1980) as well as by several papers, e.g. Penman (1977), Seed \& Duncan (1981) and Leonards \& Davidson (1984). It was discussed during the International Workshop on Dam Failures held at Purdue University, 1985.

The valley shape is given by Fig. 32 . Preliminary grouting trials had shown that the joints in the volcanic rocks forming the valley sides were too open for a grout curtain to be formed until the depth exceeded $21 \mathrm{~m}$. It was therefore decided to replace the grout curtain by a cut-off trench over this depth on both abutments, as indicated by Fig. 32. The base of the trench was made $9 \mathrm{~m}$ wide, to accommodate the drilling rigs for the grout curtain, and the sides made as steep as possible to minimize excavation. The right trench was excavated by blasting, which tended to loosen the rock. On the left side, pre-split blasting techniques were used, which caused less dis-

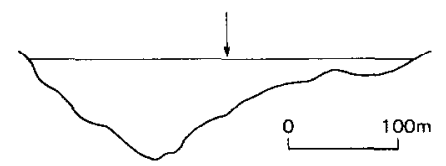

(a)

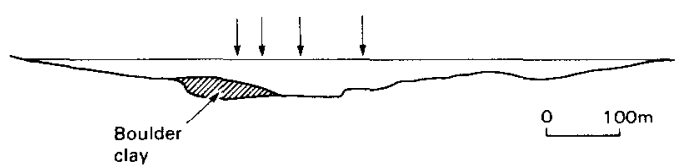

(b)

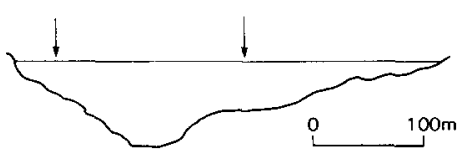

(c)

Fig. 31. Positions of core damage: (a) Hyttejuvet; (b) Balderhead; (c) Viddalsvatn 


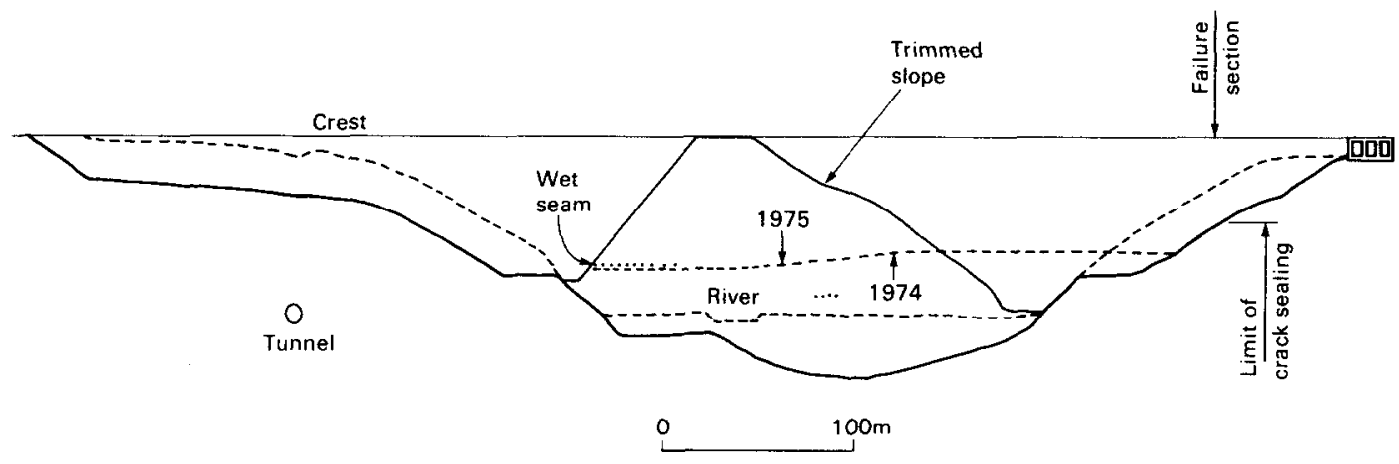

Fig. 32. Teton Dam: longitudinal section

turbance to the surrounding rock and formed smoother surfaces.

The mistake was made of placing the silt fill of the very wide core in these trenches without adequate preparation of the rock surfaces. The specification did not require special treatment to seal the numerous fissures and joints. Site personnel, concerned at the condition of the rock surface, poured grout or concrete into the wider cracks, but even this ad hoc treatment was discontinued above a height of about $50 \mathrm{~m}$ above river level, a position in the right trench close to the line of failure (from whirlpool to erosion channel in the downstream slope).

The grout cap, cast into a shallow slot in the trench floor, was only $0.9 \mathrm{~m}$ wide and finished more or less flush with the floor surface (instead of being brought up as a wall to key into the silt fill). At the time of failure, the reservoir head over the grout cap on the failure section was $30 \mathrm{~m}$, causing a hydraulic gradient of 33 over the cap, a value high enough to cause trouble in the silt if there were the slightest imperfection. The silt could easily be washed into cracks with widths of $0.2 \mathrm{~mm}$ or larger.

An analysis of arching action in the trench, using finite element techniques (Seed, Duncan \& Bieber, 1976), showed that the normal total stress on the transverse section where failure occurred was less than the reservoir pressure as shown by Fig. 33. It was therefore possible for hydraulic fracture to have initiated the piping erosion through the core.

Leonards \& Davidson (1984), from a detailed study of the placement control density tests, found that a layer of slightly drier silt had been placed across the right trench close to the failure position. A volume reduction on wetting this layer (collapse settlement) would further reduce the total stresses in the fill and ensure hydraulic fracture.

Knowledge of pre-failure behaviour of Teton was limited by the absence of instrumentation. Failure occurred rapidly, but it is not known for how long water had been passing through the core into the very permeable bedrock downstream, where the regional water-table was about $54 \mathrm{~m}$ below river level. The dangers of placing an erodible core material in direct contact with fissured bedrock had been well demonstrated: (Fetzer, 1977) at Fast Branch Dam (56 m) in 1957 and at Fontenelle $(39 \mathrm{~m})$ (Fig. 34) in 1965 (Bellport, 1967). Both dams were saved from complete failure only because their reservoirs could be lowered fast enough to prevent the erosion from forming a breach.

It was not unknown in British practice a century ago to protect core fill in cut-off trenches with a thick concrete coating over fissured rock. The following extract is from the specification for Winterbourne Reservoir, dated 1885.

$\therefore$.. If it should be considered necessary by the Engineer, the Contractor shall protect the sides of the puddle trench, or portions- of the same, by means of concrete walls on either side of the puddle.... The concrete walls shall be not less than 18 inches thick $(0.46 \mathrm{~m})$, built plumb and parallel with the centre line of the trench, smoothly faced against the puddle, and shall quite fill up all fissures in the rock and all irregularities in the sides of the trench.'

The Teton trenches could have been lined with a thick coating of reinforced concrete, tied to the grout cap and bedrock, to provide a nonerodible, reasonably watertight cut-off above the grout curtain. If the concrete coating had been extended to cover all the rock over the core contact surface, the potential for erosion of the core could have been substantially reduced.

The effectiveness of a smooth concrete contact surface to provide a leak-proof joint with a core is demonstrated by the numerous successful 


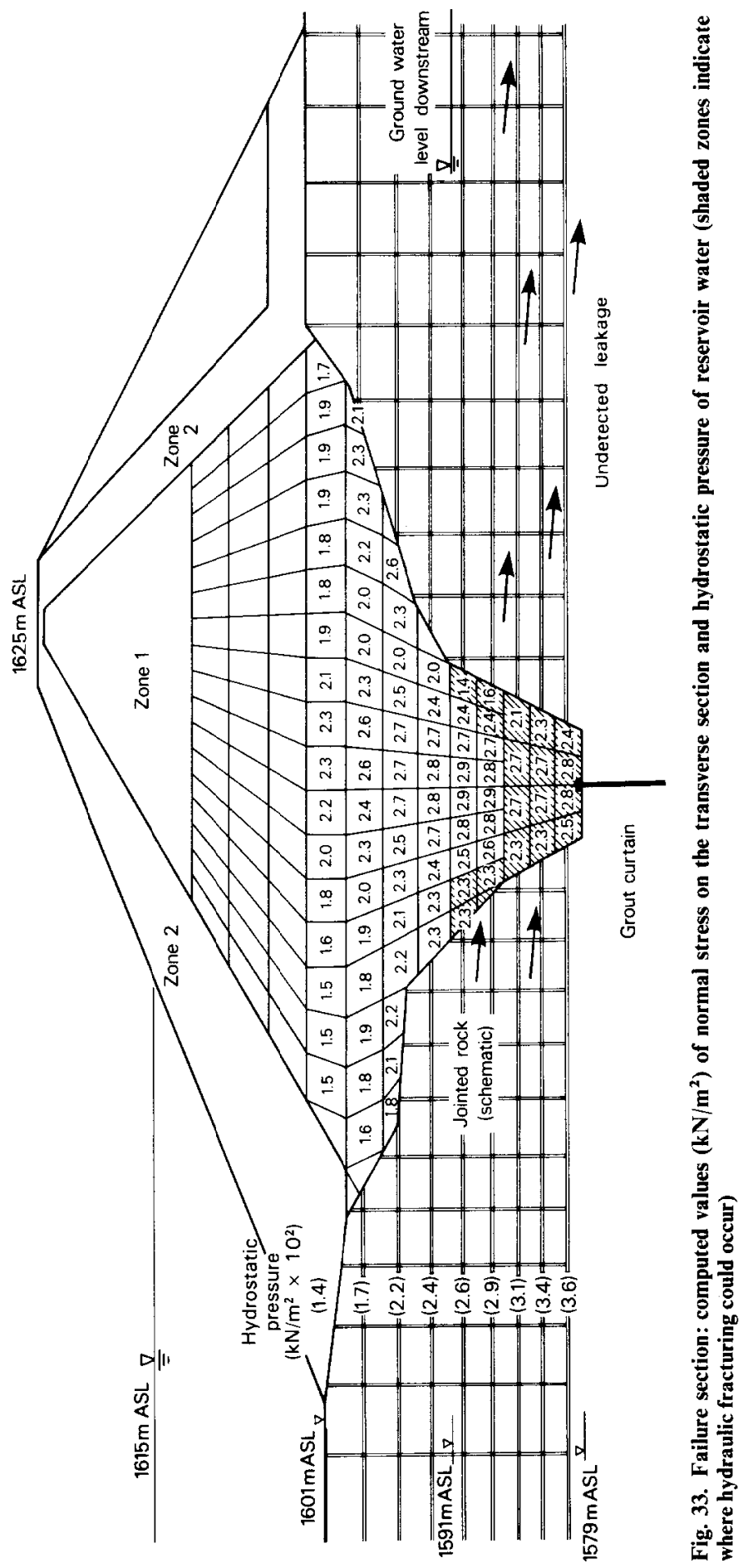




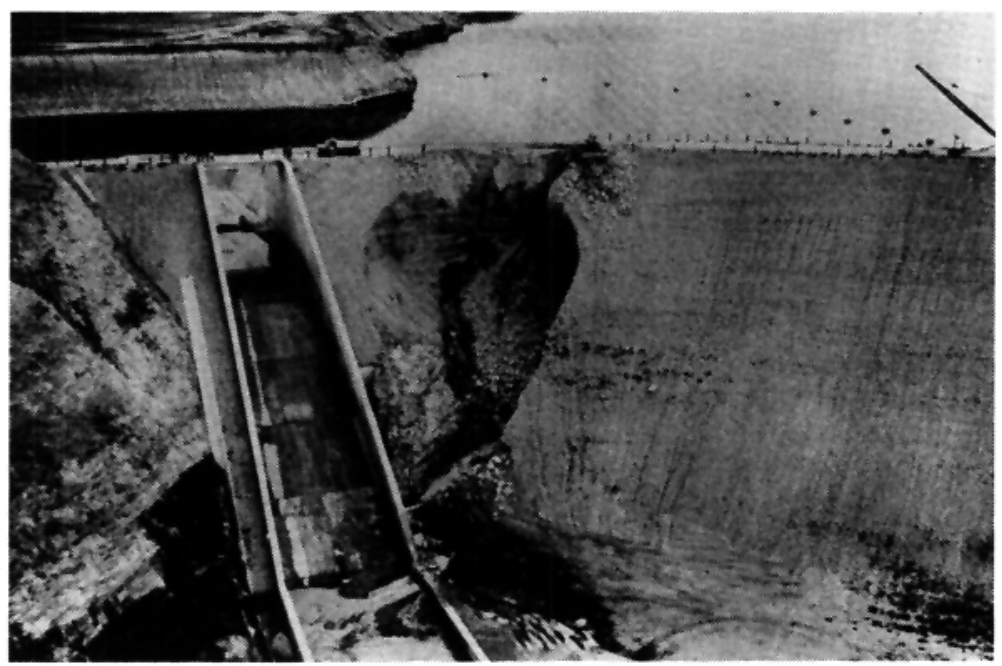

Fig. 34. Erosion damage at Fontanelle Dam

examples of almost vertical connections between concrete spillway structures and embankment. Measurements of total pressures on such a contact were made with BRS vibrating wire EP cells mounted flush in the concrete surface at Cow Green Dam. A core placement specification $c_{\mathrm{u}}=50-100 \mathrm{kN} / \mathrm{m}^{2}$ resulted in the measured total and pore pressures shown by Fig. 35 . Although dissipation of construction pore pressures reduced the total pressures, they were still comfortably above the reservoir pressure nine years after completion.

\section{Wet seams}

Although little new geotechnical information derived from the Teton failure, the subsequent detailed investigation was of considerable value. Because of the similarity between the cut-off trenches on right and left, it was hoped that the failure trigger mechanism might be revealed by exposing the left abutment and trench. An excavation of $0.68 \times 10^{6} \mathrm{~m}^{3}$ was made (the failure had removed $2.5 \times 10^{6} \mathrm{~m}^{3}$ adjacent to the right abutment) and the cut-off trench carefully exposed. Although the fill had become soaked on the upstream side and had slumped away from local overhangs, no clear signs of piping were found. It may be concluded that failure occurred on the right because there were more fissures than in the left trench and the contact surface was rougher. River erosion had exposed rock cliffs on the right side just upstream of the dam and there is little doubt that reservoir water could readily reach the upstream side of the trench. Collapse settlement of the silt fill may also have played a part in explaining why the right side failed first.
Of more interest was a horizontal wet seam discovered near the bottom of the excavation on its right side, passing almost through the wide core from upstream to downstream. When it was exposed on 5 October 1977, 16 months after

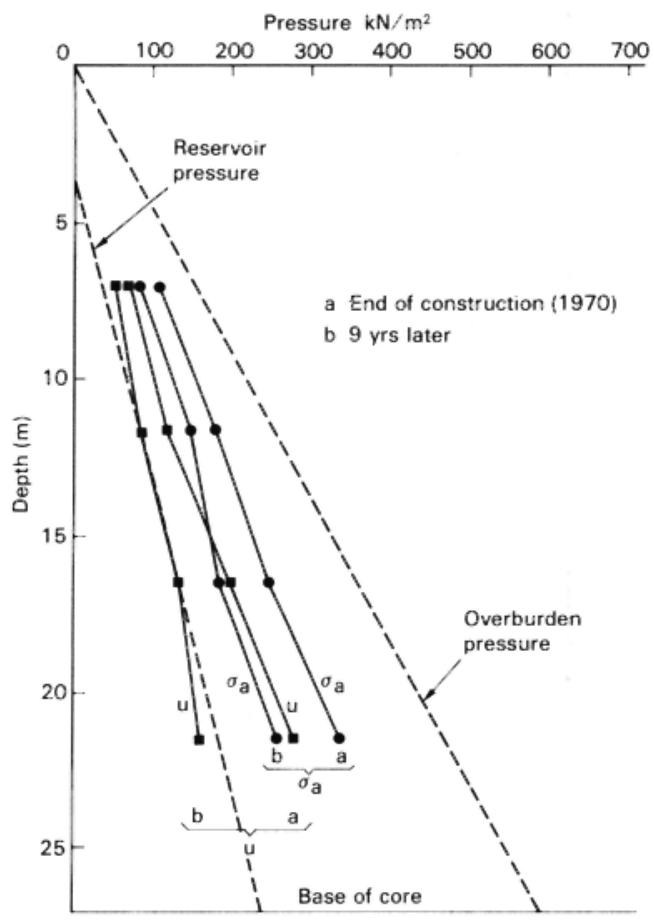

Fig. 35. Total pressures measured at the concrete-clay interface, Cow Green Dam 


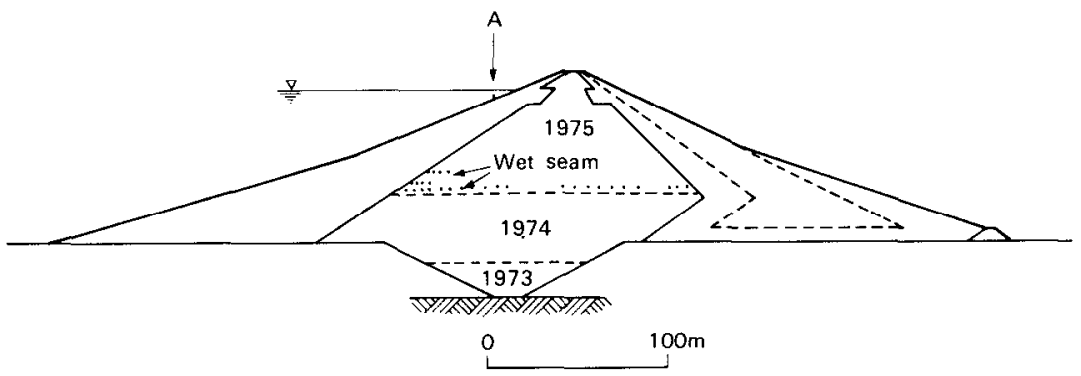

Fig. 36. Teton Dam: major section

failure and 30 months after placement, water was seeping from it and continued for several months. Investigation by adit and boreholes showed that there were thin wet seams (about $0.2 \mathrm{~m}$ thick) extending over about five acres in the remainder of the dam. The majority of seams were found to be slightly above the fill surface during the 1974-75 winter shut-down (Fig. 36). Had the wet seams been below the winter surface, it was thought that they might have been caused by melting ice lenses, although it was difficult to see how a sufficient volume of water could have been drawn out of the dry silt fill to form ice lenses.

After the 1974-75 winter shut-down, fill placement began on the lower, left side during periods of rain and snowfall. During the first few weeks there was a shortage of inspectors and it has been suggested that the wet seams originated in layers of wet fill and the effects of ponded surface water. This seems improbable because it would be impossible to operate the heavy placing machines on very wet silt. The ability of the silt fill, placed on average $1.3 \%$ dry of optimum, to absorb water was demonstrated when a borehole, put down into the left trench for hydraulic fracture tests, lost $13 \mathrm{~m}^{3}$ as it was drilled from $30-45 \mathrm{~m}$ depth. During the subsequent excavation, no evidence of the water was found. Sherard (1985b) has suggested that the wet seams may have been caused by hydraulic fracture due to reduction of $\sigma_{\mathrm{v}}$ by arching action both upstream to downstream and between abutments. This action could develop if the fill below the shut-down surface settled, possibly by collapse settlement on wetting by river water. That this hydraulic fracture did not lead to failure may be due to the large width of the core and collapse of the roof of the fracture to form a looser saturated seam of silt with a low enough permeability to prevent erosive flow velocities.

Water in this extensive, loose, saturated seam could become trapped when the breach cut the arch between abutments, allowing the weight of the dam to seal the edges. Some upstreamdownstream arching may have remained. One of the survey stations (Fig. 36, A) that had settled $49 \mathrm{~mm}$ during the seven months of impounding settled a further $58 \mathrm{~mm}$ on failure: this may have been influenced by unmeasured horizontal movement towards the breach. Standpipe piezometers installed in some of the exploratory boreholes about four months after first exposure of the seam(s) showed a maximum pressure of only $1.5 \mathrm{~m}$ head of water, which fell to $0.5 \mathrm{~m}$ in six months.

While this concept has not been accepted by some other engineers concerned with Teton, Sherard has observed wet seams in other cores. At Yard's Creek ( $24 \mathrm{~m}$ ) (USA) they were exposed in a trial pit made through the core for another purpose and at Manicouagan $3(108 \mathrm{~m})$ (Canada) and Guapo $(60 \mathrm{~m})$ (Venezuela) they were found by using a very special exploratory boring technique that required no drilling fluid. The wet seams would not have been discovered at Teton had the exploratory excavation not been taken to the exceptional depth of $70 \mathrm{~m}$. There may be many undetected cases of wet seams in the cores of existing dams.

\section{Wet cores}

In Britain, after the experience at Balderhead, there was a return to wetter corcs and those of Scammonden $(70 \mathrm{~m})$ and Llyn Brianne $(90 \mathrm{~m})$ were placed wet of optimum. Groups of the BRS vibrating wire EP cells (Figs 37 and 38) were installed in the middle of the core at three levels during construction of Scammonden (Penman \& Mitchell, 1970). Measured values showed that the total pressures at the end of construction ( $a$ in Fig. 39) comfortably exceeded the expected water pressures from a full reservoir, with lowest values $\left(\sigma_{\mathrm{h}}\right)$ in the direction across the core. Effective stresses gradually increased with pore pressure dissipation and total pressures decreased towards steady state conditions. After ten years, some of the EP cells failed: total pressures derived from the remaining cells after 14 years are shown at $b$, in Fig. 39. Pore pressures, measured by five hydraulic piezometers placed across the core at 


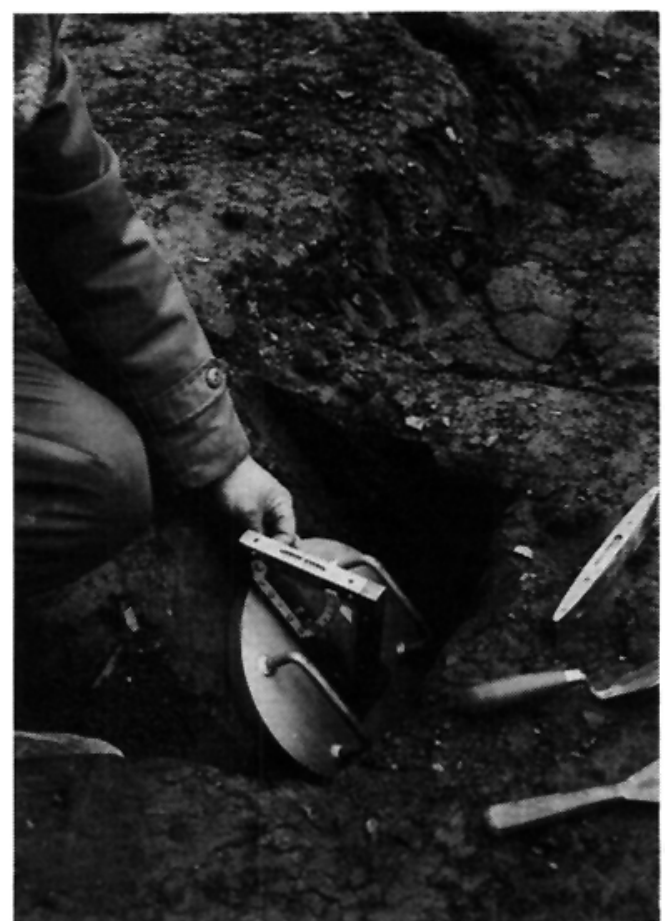

Fig. 37. Preparing a $45^{\circ}$ surface for an EP cell

each level, show a relatively uniform fall from reservoir pressure upstream to the filter drain at the downstream face. It can therefore be expected that total pressures in the core will increase from mid-width, where the measurements were made, towards the upstream face of the core.
At Llyn Brianne, oil-filled EP cells $250 \mathrm{~mm}$ dia. and only $10 \mathrm{~mm}$ thick were placed in both core and rockfill shoulders. Measured values, described by Carlyle (1973) showed that there was no risk of hydraulic fracture. The cells (Glotzl manufacture) have a simple diaphragm transducer that uses the principle of hydraulic fracture in its operation. A small plastic diaphragm, subjected to the pressure of the oil enclosed in the cell, is pressed against a flat surface containing two holes. Flexible tubes connected to these holes form an external oil circuit with a pump and pressure gauge in an instrument house. When the pressure of oil applied to one of the holes exceeds that in the cell, the diaphragm is pushed away from the flat surface, allowing oil to return through the second connecting tube. The volume change in the cell is small enough not to affect the earth pressure. When pumping is stopped, leakage continues under the diaphragm until pressures balance. Microscopic inspection of some of the flat surfaces has shown that they contain machining marks which form fine ridges between the holes. These will cause stress concentrations at their contáct with the diaphragm and assist in making a seal with very little excess pressure from the oil enclosed in the cell.

A thin oil is normally used in the circulating system and must be kept very clean. Any fine particles (soil in the tubes during installation etc.) may damage the sealing surface or lodge under the diaphragm. The oil must also be chemically compatible with the diaphragm: damage has been caused by use of the wrong oil.

This type of EP cell has the advantages of robust simplicity and small thickness over an area

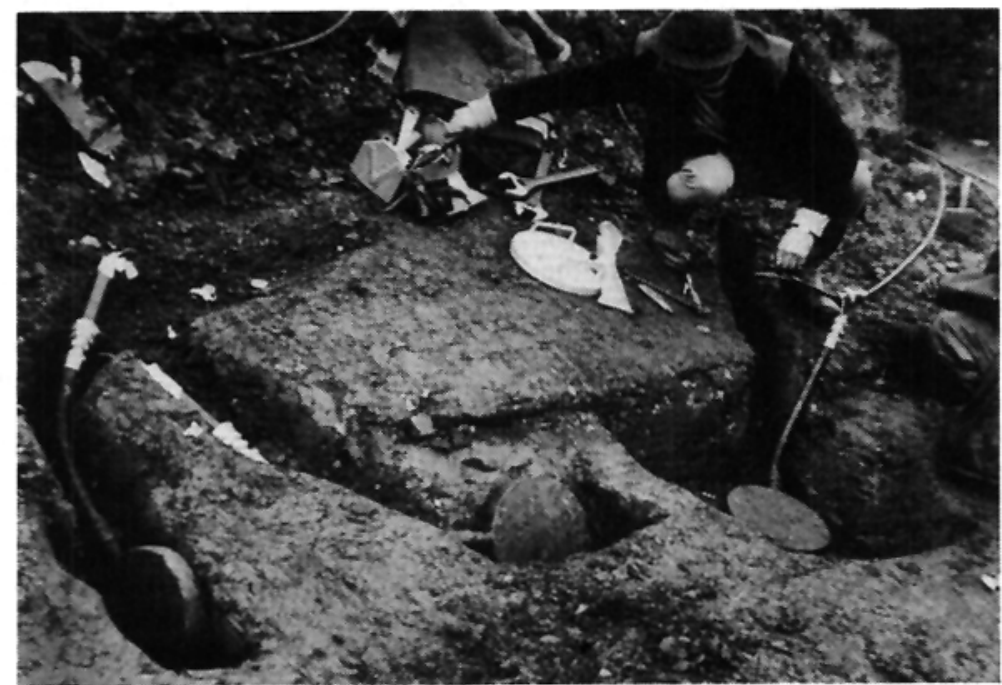

Fig. 38. Three of a group of five EP cells 


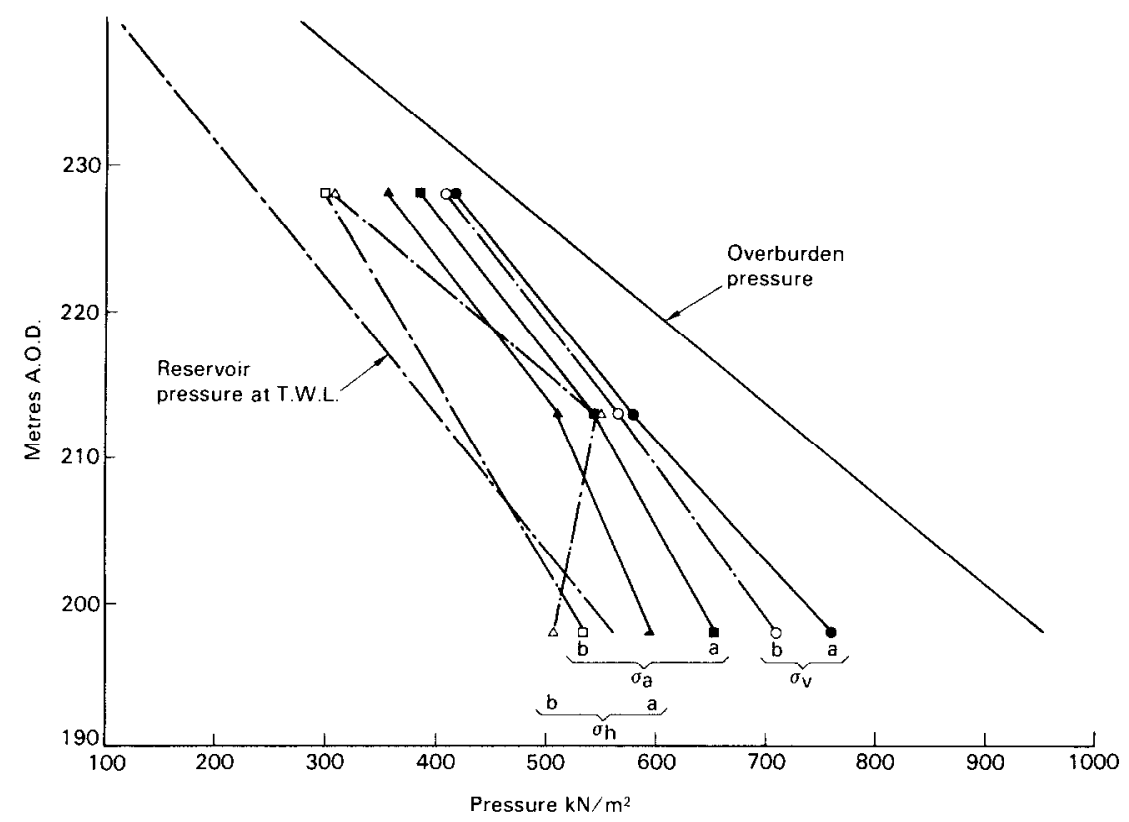

Fig. 39. Total pressures in the clay core of Scammonden Dam on completion in 1969 (a) and in March 1984 (b)

large enough to minimize cell action. It has become one of the most widely used EP cells for total stress measurements in dams.

\section{old dams}

A large number of the world's dams contain no instruments and inspecting engineers may have to resort to various forms of in situ testing. In Britain, many dams built before 1950 had cores of puddled clay and the BRS has begun studies of their condition. Various methods have been used to measure total and effective stresses in these cores, including hydraulic fracture tests from piezometers, measurements with spade-shaped, oil-filled EP cells and the self-boring pressuremeter. This work has been described by Penman \& Charles (1981) and Charles \& Watts (1986). The spade-shaped cells have been pushed into the clay to measure $\sigma_{\mathrm{h}}$ and $\sigma_{\mathrm{a}}$, but there has been no means for measuring $\sigma_{\mathrm{v}}$. Currently an apparatus is being developed at the BRS which will insert EP cells to measure $\sigma_{\mathrm{v}}$ from a $150 \mathrm{~mm}$ dia. vertical borehole. The cells can be pushed up to $0.6 \mathrm{~m}$ away from the borehole.

\section{CONCLUDING DISCUSSION AND REMARKS}

The major international organizations, ICOLD and the International Society for Soil Mechanics and Foundation Engineering, had their origins in the 1930 s and through their regular conferences have provided a unique exchange of experience and development through interaction of ideas and methods. The contribution from soil mechanics has played a vital role in improving design methods for embankment dams, helping to bring them to the leading position that they hold today.

One of the first problems to be tackled was that of slope stability: it was sometimes assumed that the factor of safety of a dam was synonymous with the factor of safety against a slip. Design improvements and analysis using effective stress required testing by back analysis of failures and knowledge of pore pressures in the field. In general, the verification of design assumptions relies on detailed observation of the behaviour of the dam. Knowledge of soil behaviour and the sophistication of stability analysis for complex slip surfaces has reached such a stage that there can be considerable confidence that safe slopes can be designed.

The fact that some slips still occur in recently designed dams reflects a misapplication of design methods rather than weaknesses in the methods. Misunderstanding of site conditions through what may later be condemned as an inadequate site investigation may lie at the root of some failures, but when consideration is given to methods of procurement for site investigation it is perhaps not surprising: lowest tenders based on lengths of holes drilled and numbers of samples taken is not an approach that is likely to reveal the hidden secrets of the site: 
Part of the trouble is due to the apparent complexity and procrastination in the promotion of a new scheme. Reeve (1986) in his Presidential address has drawn attention to the long lead time that is common to the construction of a dam and gave an example where this time was more than 13 years. The site investigation was made after four years and was sufficient to show that the scheme was feasible, about nine years before construction started. During that time the design was modified, not in the light of further site investigation, but to satisfy some further twist in the restrictions imposed by planning requirements. There have been cases where rockfill for the shoulders has had to be replaced by weathered mudstone from the reservoir area because of an objection to expansion of an existing quarry. Unfortunately, once approval has finally been obtained, it is expected that the dam will be built in minimum time, at breakneck speed, to provide return on capital with minimum delay. For a potentially dangerous structure with an unspecified life span, this may seem less than ideal.

However intense the site investigations may have been, the exposures made once construction starts form a valuable supplement. There is much to be said for a 'design-as-you-go' approach and it is perhaps unfortunate that so many specifications and contractual arrangements restrict its use. Speed of construction also operates against it, leaving little time for reassessment of design when unexpected features are revealed.

Speed helps to produce maximum pore pressures at the end of construction, making this the most dangerous time for slips. This has the advantage that the failure does not usually involve the release of reservoir water.

The execution of complex analyses by computer can give a false sense of security. In the knowledge that large numbers of slip surfaces have been subjected to refined analysis, the fact that none of the surfaces passed along some obvious feature such as a soft clay layer and that unrealistic values were chosen for $c^{\prime}$ and $\varphi^{\prime}$ may be overlooked.

It can be argued that, as a protection against progressive failure, design using peak values for $\varphi^{\prime}$ should accept $c^{\prime}-0$. It is now recognized that the use of $c^{\prime}$ with a constant $\varphi^{\prime}$ was only a convenient way of representing the strength characteristics of a soil. There are many more accurate ways: one of the more practical is the use of a curved failure envelope, as discussed by Charles \& Soares $(1984 a, b)$ who have proposed new methods for stability analysis of slopes.

It may be more rational to design for acceptable movements rather than to guard against the completely unacceptable situation of slip failure by the use of small factors of safety. Provided that realistic parameters for the deformation properties of fill and foundation can be obtained, there are two- and three-dimensional finite element programs that will enable predictions to be made. Their accuracy must be assessed by field measurements and in this connection the horizontal plate gauge has proved invaluable. It can only be used in conjunction with a system for precise surveying that will show movements of the dam in relation to remote, fixed positions. Such observations, even without the horizontal plate gauge, will determine whether movements are becoming unacceptable during construction and, in some circumstances, could show the development of undesirable trends in time for remedial works to be carried out.

A difficulty with this approach is to determine the magnitude of acceptable movements. Progressive failure in brittle clays may develop with remarkably small external movements, whereas, provided that outlet works and other structures have been positioned to allow for it, other fills may undergo large deformations without damage. This may not be acceptable, however, when the watertight element of the dam takes the form of an upstream membrane. There is always a problem of differential movement at the plinth where the membrane bridges from compressible fill to rigid structure. Minimum height and therefore minimum depth of fill behind the structure will help to limit movements, but special flexibility to allow some movement is always needed.

Perhaps the most dangerous form of failure is that developing through erosive seepage under conditions of an almost full reservoir. It can be argued that all cases originate in some form of hydraulic fracture, i.e. total stresses in some part of the water retaining structure are insufficient to withstand the reservoir water pressure and the resulting leaks are able to erode material. The apparently simple check on this situation of observing the volume and quality of leaking water is often most difficult to make. Permeable ground downstream of the waterproof element (and particularly when the groundwater table is low as at Teton) makes it impossible to collect all seeping water. Indications may be given by the pressure distribution measured by foundation piezometers and some water may be collected for examination from relief wells, underdrains etc., but there is a need for the development of satisfactory (preferably automatic) systems that will detect increasing leakage and turbidity.

Water may be lost from reservoirs in many ways not connected with the dam. There are many well-known examples in karstic rock where undetected caverns have opened up sufficiently to 
prevent the reservoir from filling, but without causing any danger to the dam. To a lesser extent, seepage may occur through the foundation, particularly in fissured rock, without erosion or development of destabilizing pressures. At the contact, however, between clay core and foundation, it is desirable to ensure that total pressures always exceed the reservoir pressure. To this end, not only should core material be sufficiently flexible, but the surface should be relatively smooth. On a rock foundation, it may be necessary to provide a concrete coating.

It is difficult to avoid discontinuities in rolled clay fill. The natural fabric was almost completely destroyed in puddled clay by raising its water content (to reduce $c_{\mathrm{u}}$ ) and thoroughly mixing it in a powerful pug mill and there is little evidence of discontinuities being introduced by the method of placing. Inspection of some old cores has shown that some fabric develops with ageing and there was evidence of slickensides, presumably caused by differential movements. There are also many cases of cores built of clays that had been wetted and mixed with shovels on the core itself, not passed through a pug mill.

Rolled clay cores, placed by large machines, may not only retain some of the original fabric, preserved in lumps of fill, but also contain shear surfaces and discontinuities left by the placing machines. It is therefore of even greater importance to ensure that total pressures across these features are sufficient to avoid hydraulic separation by reservoir water pressure.

Towards the end of the puddled clay era, unsuccessful attempts were made to mechanize the traditional compaction by foot. Rolled clay cores were made stronger to accommodate the heavy machines, but it is encouraging to see recent examples showing a return to much softer flexible cores. The core for Kielder Dam (Millmore \& McNicol, 1983) was designed to have construction pore pressures that were higher than the reservoir pressure to avoid the possibility of hydraulic fracture, following the recommendations of Penman \& Charles (1979). Laboratory tests had shown that this could be achieved by limiting the core strength to about $c_{\mathrm{u}}=100 \mathrm{kN} / \mathrm{m}^{2}$.

A very wet core was placed in the Monasavu Dam $(85 \mathrm{~m})$ in Fiji (Knight, Worner \& McClung, 1982). The residual soil $\left(I_{\mathrm{p}}=52\right)$ was at about $20 \%$ wet of Proctor optimum in the borrow area and the monthly rainfall of $0.2-0.4 \mathrm{~m}$ prevented natural drying. It was placed by light bulldozers fitted with wide tracks and had $c_{\mathrm{u}}=14-26$ $\mathrm{kN} / \mathrm{m}^{2}$, close to the values of the old puddled clay. Currently, the core of Wadaslintang $(120 \mathrm{~m})$ in Indonesia is being constructed from a heavy, reddish-brown clay, soft enough to require marsh tractors.

Leakage seldom corresponds to a laboratorydetermined value of $k$ for the core material. Seeps through imperfections may do little harm if the velocity is low enough and the material does not readily erode. If a discontinuity is forced open by water pressure, soil particles forming the walls of the fracture find themselves under zero effective stress and their resistance to being dragged away by water flow depends on their attraction to or interlocking with their neighbouring particles. This ability may be a function of the tensile strength of the soil, measured in terms of effective stresses. Empirical tests such as Sherard's pinhole test (Sherard, Dunnigan, Decker \& Steele, 1976) give a practical guide to the erosion resistance of soils, but there is room for fundamental research into this problem.

No designer can remain satisfied with his design without knowledge of how well it is working in practice. Design improvements rely on feedback from the structure on its behaviour under normal and abnormal conditions. Instrumentation in dams is essential to obtain this information and proper provision should be made in all new schemes to ensure collection of accurate, pertinent records of behaviour.

Research into the behaviour of embankment dams goes hand in hand with geotechnical research and there is a need for this work to be carried out and guided by an independent body representing the interests of owners, consultants and contractors. Costs must be shared and this may be best effected by government funding. Such research and development will continue to support an industry responsible for dams not only in this country, but it is also essential to maintain our involvement in dam projects worldwide.

There is no doubt that progress achieved in the geotechnical field has been fundamental in the satisfactory development of the embankment dam as the major type of dam in use today.

\section{ACKNOWLEDGEMENTS}

The Author wishes to thank Mr B. Boden, and through him, both the British Geotechnical Society Committee (of which he is Chairman) for the invitation to give the Rankine Lecture and the Geotechnics Division of the BRS (of which he is Head) for encouragement and advice.

Dr J. A. Charles, Head of the Dams Section, made numerous valuable contributions during the preparation of the Paper. Much of the material has been drawn from work carried out by the Author while with the BRS: permission to use it has been kindly given by the Director, who 
also made available drawing office and photographic facilities. The Author owes a debt of gratitude to the owners, consultants and contractors with whom he has worked and to his colleagues at the BRS, including $\mathrm{Mr} \mathrm{D}$. Burford and $\mathrm{Mr}$ K. S. Watts. Mrs Penman assisted with references and in both reading and typing the text.

\section{REFERENCES}

Anagnosti, P. (1965). An analysis of stresses and deformations in the wide clay core of a rockfill dam. Proc. 6th Int. Conf. Soil Mech. Fdn Engng, Montreal 2, 447-450.

Baines, J. A., Newman, V. G., Hannah, I. W., Douglas, T. H. \& Carlyle, W. J. (1983). Dinorwig pumped storage system. Proc. Instn Civ. Engrs, Part I 74, 635-680.

Banks, J. A. (1948). Construction of Muirhead reservoir, Scotland. Proc. 2nd Int. Conf. Soil Mech. Fdn Engng, Rotterdam 2, 23-31.

Banks, J. A. (1952). Problems in the design and construction of Knockendon Dam. Proc. Instn Civ. Engrs, Part 1 1, No. 4, 423-443.

Beavan, G. C. G., Colback, P. S. B. \& Hodgson, R. L. P. (1977). Construction pore pressures in clay cores of dams. Proc. 9th Int. Conf. Soil Mech. Fdn Engng, Tokyo 1, 391-394.

Bellport, B. P. (1967). Bureau of Reclamation experience in stabilising embankment of Fontenelle earth dam. Trans. 9th Int. Congr. Large Dams, Istanbul 1, $67-79$.

Binnie, A. R. (1877). Water supply, rainfall, reservoirs, conduits and distribution. Lectures at School of Military Engineering, Chatham. Chatham: Royal Engineers Institute.

Binnie, G. M. (1978). The collapse of Dale Dyke dam in retrospect. Q. J. Engng Geol. 11, 305-324.

Binnie, G. M. (1981). Early Victorian water engineers. London: Telford.

Bishop, A. W. (1952). The stability of earth dams. PhD thesis, University of London.

Bishop, A. W. (1955). The use of the slip circle in the stability analysis of slopes. Geotechnique 5, No. 1, 7-17.

Bishop, A. W., Kennard, M. F. \& Penman, A. D. M. (1960). Pore pressure observations at Selset dam. In Pore pressure and suction in soils, pp. 91-102. London: Butterworths.

Bishop, A. W. \& Vaughan, P. R. (1962). Selset Reservoir: design and performance of the embankment. Proc. Instn Civ. Engrs 21, 305-346.

Black, W. P. M., Croney, D. \& Jacobs, J. C. (1958). Field studies of the movement of soil moisture. Road Research Technical Paper No. 41, HMSO, London.

Blight, G. E. (1973). Stresses in narrow cores and core trenches in dams. Trans. 1lth Int. Congr. Large Dams, Madrid 3, 63-79.

Buckley, R. B. (1898). Discussion on Reservoirs in India. Minut. Proc. Insin Civ. Engrs 132, 213-217.

Carlyle, W. J. (1973). The design and performance of the core of Brianne dam. Trans. 1Ith Int. Congr. Large Dams, Madrid 3, 431-455. de Carvalho, L. H. (1982). Discussion on Q55. Trans. 14th Int. Congr. Large Dams, Rio de Janeiro 5, 551554.

Celestino, T. B. \& Duncan, J. M. (1981). Simplified search for noncircular slip surface. Proc. 10th Int. Conf. Soil Mech. Fdn Engng, Stockholm 3, 391-394.

Charles, J. A. (1979). General report: methods of treatment of clay fills. In Clay fills, pp. 315-321. London: Institution of Civil Engineers.

Charles, J. A. \& Soares, M. M. (1984a). Stability of compacted rockfill slopes. Géotechnique 34, No. 1, 61-70.

Charles, J. A. \& Soares, M. M. (1984b). The stability of slopes in soils with nonlinear failure envelopes. Can. Geotech. J. 21, No. 3, 397-406.

Charles, J. A. \& Watts, K. S. (1986). The measurement and significance of horizontal earth pressures in the puddle clay cores of old earth dams. Submitted to Proc. Instn Civ. Engrs.

Chugh, A. K. (1986). Variable factor of safety in slope stability analysis. Géotechnique 36, No. 1, 57-64.

Collins, P. M. G. \& Humphreys, J. D. (1974). Winscar reservoir. J. Instn Wat. Engrs 28, No. 1, 17-46.

Cooling, L. F. (1936). Discussion on Shearing resistance of soil. Proc. Ist Int. Conf. Soil Mech. Fdn Engng, Harvard 3, 39-40.

Cooling, L. F. \& Golder, H. Q. (1942). The analysis of the failure of an earth dam during construction. $J$. Instn Civ. Engrs 19, No. 1, 38-55.

Costa Filho, L. de M. (1984). Private communication.

Dennehy, J. P. (1979). The remoulded undrained shear strength of cohesive soils and its influence on the suitability of embankment fill. In Clay fills, pp. 8794. London: Institution of Civil Engineers.

Dibiagio, E. \& Kjaernsli, B. (1985). Instrumentation of Norwegian embankment dams. Trans. 15th Int. Congr. Large Dams, Lausanne 1, 1071-1101.

Dunstan, M. R. H. (1981). Rolled concrete for dams: a laboratory study of the properties of high flyash content concrete. CIRIA Technical Note 105, Construction Industry Research and Information Association, London.

Fetzer, C. A. (1977). Seepage problems of earth and rockfill dams on rock foundations. Int. Wat. Pwr Dam Constr. 29, No. 8, 38-44.

Goldbeck, A. T. \& Smith, E. B. (1916). An apparatus for determining soil pressure. Proc. Am. Soc. Test. Mater, 16, No. 2, 309-319.

Gordon, J. L. \& Duguid, D. R. (1970). Experiences with cracking at Duncan dam. Trans. 10th Int. Congr. Large Dams, Montreal 1, 469-485.

Gosschalk, E. M. \& Kulasinghe, A. N. S. (1985). Kotmale dam and observations on CFRD. Proc. Am. Soc. Civ. Engrs Symp. Concrete Face Rockfill Dams, Detroit, pp. 379-395.

Hamilton, D. M. (1986). Private communication.

Hollingsworth, H., Conner, T. R. \& Anderson, V. E. (1985). Design of Deer Creek dam. Proc. Am. Soc. Civ. Engrs Symp. Concrete Face Rockfill Dams, Detroit, pp. 541-558.

Independent Panel (1976). Failure of Teton dam. Report to US Department of Interior and State of Idaho, US Government Printing Office, Washington.

Interior Review Group (1977). Failure of Teton dam. 
Report on findings by Department of Interior Review Group, US Government Printing Office, Washington.

Interior Review Group (1980). Failure of Teton dam. Final report by Department of Interior Review Group, US Government Printing Office, Washington.

Janbu, N. (1957). Earth pressures and bearing capacity calculations by generalised procedure of slices. Proc. 4th Int. Conf. Soil Mech. Fdn Engng, London 2, 207212.

Kennard, M. F. (1983). Carsington Reservoir--report on consideration of embankment stability. Confidential Report No. 1362 to Shephard Hill. Rofe, Kennard \& Lapworth, Sutton.

Kennard, M. F., Lovenbury, H. T., Chartres, F. R. D. \& Hoskins, C. G. (1979). Shear strength specification for clay fills. In Clay fills, pp. 143-147. London: Institution of Civil Engineers.

Kerisel, J. (1985). The history of geotechnical engineering up until 1700. Proc. 11th Int. Conf. Soil Mech. Fdn Engng, San Francisco, Golden Jubilee volume, pp. 3-93.

Kjaernsli, B. \& Torblaa, I. (1968). Leakage through horizontal cracks in the core of Hyttejuvet dam. Norw. Geotech. Inst. Publ. No. 80, 39-47.

Knight, D. J., Worner, N. M. \& McClung, J. E. (1982). Materials and construction methods for a very wet clay core rockfill dam at Monasavu Falls, Fiji. Trans. 14th Int. Congr Large Dams, Rio de Janeiro 4, $294-303$.

Kramer, R. W. (1982). Discussion on Safety of dams in operation. Trans. 14th Int. Congr. Large Dams, Rio de Janeiro 5, 166-169.

Leonards, G. A. \& Davidson, L. W. (1984). Reconsideration of failure initiating mechanisms for Teton dam. Proc. Int. Conf. Case Histories in Geotechnical Engineering. St Louis 3, 1103-1113.

Little, A. L. \& Price, V. E. (1958). The use of an electronic computer for slope stability analysis. Géotechnique 8, No. 3, 113-120.

Löfquist, B. (1951a). Calculating a concrete core wall. Trans. 4th Int. Congr. Large Dams, New Delhi 1, $111-133$

Lofquist, B. (1951b). Earth pressure in a thin impervious core. Trans. 4th Int. Congr. Large Dams, New Delhi, 1, 99-109.

Löfquist, B. (1957). Discussion on Cracking in earth dams. Proc. 4th Int. Conf. Soil Mech. Fdn Enyng, London 3, 261-262.

Lowe, J. (1962). Discussion on Use of rollcrete in earth dams (unpublished). Ist Am. Soc. Civ. Engrs Water Resources Engineering Conf., Omaha. (Reproduced in part in Proc. Int. Conf. Rolled Concrete for Dams, 1981, pp. W-1-W-5. London: Construction Industry Research and Information Association.)

Lowe, J. (1970). Recent development in the design and construction of earth and rockfill dams. Trans. 10th Int. Congr. Large Dams, Montreal 5, 1-28.

Mackey, P. G. (1985). Rehabilitation to meet reservoir safety and flood criteria. Trans. 15th Int. Congr. Large Dams, Lausanne 4, 899-919.

Magnusson, G. (1948). Research methods and instruments for the measurement of stresses and deforma- tions in earth dams. Trans. 3rd Int. Congr. Large Dams, Stockholm 2, Q9, R32.

de Mello, V. F. B. (1977). Reflections on design decisions of practical significance to embankment dams. 17th Rankine Lecture. Géotechnique 27, No. 3, 281354.

de Mello, V. F. B. (1982). A case history of a major construction period dam failure, pp. 63-78. Brussels: Comité d'Hommage au Professeur E. de Beer.

Millmore, J. P. \& McNicol, R. (1983). Geotechnical aspects of the Kielder Dam. Proc. Instn. Civ. Engrs, Part $174,805-836$.

Morgenstern, N. R. \& Price, V. E. (1965). The analysis of the stability of general slip surfaces. Geotechnique 15, No. 1, 79-93.

Nagarkar, P. K., Kulkarni, R. P., Kulkarni, M. V. \& Kulkarni, D. G. (1981). Failure of a monozone earth dam of expansive clay. Proc. 10th Int. Conf. Soil Mech. Fdn Engng, Stockholm 3, 491-494.

Penman, A. D. M. (1956). A field piezometer apparatus. Géotechnique 6, No. 2, 57-65.

Penman, A. D. M. (1971). Rockfill. J. Instn Highw. Engrs 18, No. 12.

Penman, A. D. M. (1977). The failure of Teton dam. Ground Engng 10, No. 6, 18-27.

Penman, A. D. M. (1979). Construction pore pressures in two earth dams. In Clay fills, pp. 177-187. London: Institution of Civil Engineers.

Penman, A. D. M. (1982). Materials and construction methods for embankment dams and cofferdams. General Report. Trans. 14th Int. Congr. Large Dams, Rio de Janeiro 4, 1105-1228.

Penman, A. D. M., Burland, J. B. \& Charles, J. A. (1971). Observed and predicted deformations in a large embankment dam during construction. Proc. Instn Civ. Engrs 49, 1-21.

Penman, A. D. M. \& Charles, J. A. (1974). Measuring movements of embankment dams. Proc. Symp. Field Instrumentation in Geotechnical Engineering, pp. 341-358. London: Butterworths.

Penman, A. D. M. \& Charles, J. A. (1975). Predicted deformation of the upstream membrane of a rockfill dam. Ground Engng 8, No. 6, 47-48.

Penman, A. D. M. \& Charles, J. A. (1976). The quality and suitability of rockfill used in dam construction. Trans. 12th Int. Congr. Large Dams, Mexico City 1, 533-556.

Penman, A. D. M. \& Charles, J. A. (1979). The influence of their interfaces on the behaviour of clay cores in embankment dams. Trans. 13th Int. Congr. Large Dams, New Delhi 1, 695-714.

Penman, A. D. M. \& Charles, J. A. (1981). Assessing the risk of hydraulic fracture in dam cores. Proc. 10th Int. Conf. Soil Mech. Fdn Engng, Stockholm 1, 457462.

Penman, A. D. M. \& Charles, J. A. (1982). An improved horizontal plate gauge. Géotechnique 32, No. 3, 278282.

Penman, A. D. M. \& Charles, J. A. (1985a). Behaviour of rockfill dam with asphaltic membrane. Proc. 11th Int. Conf. Soil Mech. Fdn Engng, San Francisco 4, 2011-2014.

Penman, A. D. M. \& Charles, J. A. (1985b). A comparison between observed and predicted deformations of 
an embankment dam with a central asphaltic core. Trans. I5th Int. Congr. Large Dams, Lausanne 1, 1373-1389.

Penman, A. D. M., Charles, J. A., Nash, J. K. T. L. \& Humphreys, J. D. (1975). Performance of culvert under Winscar dam. Géotechnique 25, No. 4, $713-$ 730.

Penman, A. D. M. \& Hussain, A. (1984). Deflection measurements of the upstream asphaltic membrane of Marchlyn dam. Int. Wat. Pwr Dam Constr. 36, No. 9, 33-37.

Penman, A. D. M. \& Mitchell, P. B. (1970). Initial behaviour of Scammonden dam. Trans. I0th Int. Congr. Large Dams, Montreal 1, 723-747.

Pessoa, J. C. (1982). Discussion on Q55. Trans. 14th Int. Congr. Large Dams, Rio de Janeiro 5, 680-682.

Rao, K. L. (1951). Earth dams ancient and modern in Madras State. Trans. 4th Int. Congr. Large Dams, New Delhi 1, 285-301.

Rawlinson, R. (1883). Discussion on Waterworks. Minut. Proc. Instn Civ. Engrs 74, 163-167.

Reeve, D. A. D. (1986). Presidential address 1985. Proc. Instn Civ. Engrs, Part 1 80, 1-12.

Rogers, W. S. (1935). A soil moisture meter. J. Agric Soc., Part 3 25, 326-343.

Rowe, P. W. (1972). The relevance of soil fabric to site investigation practice. 12th Rankine Lecture. Géotechnique 22, No. 2, 195-300.

Sarma, S. K. (1973). Stability analysis of embankments and slopes. Géotechnique 23, No. 3, 423-433.

Schnitter, N. J. (1979). Discussion on Deterioration or failure of dams. Trans. 13th Int. Congr. Large Dams, New Delhi 5, 488-493.

Seed, H. B. \& Duncan, J. M. (1981). The Teton dam failure-a retrospective review. Proc. I0th Int. Conf. Soil Mech. Fdn Engng, Stockholm 4, 219-238.

Seed, H. B., Leps, T. M., Duncan, J. M. \& Bieber, R. E. (1976). Hydraulic fracturing and its possible role in the Teton dam failure. In Failure of Teton dam. Report to US Department of Interior and State of Idaho, Appendix D, US Government Printing Office, Washington.

Sherard, J. L. (1973). Embankment dam cracking. In Embankment dam engineering, Casagrande volume, pp. 271-353. New York: Wiley.

Sherard, J. L. (1985a). The upstream zone in concreteface rockfill dams. Proc. Am. Soc. Civ. Engrs Symp. Concrete Face Rockfill Dams, Detroit, pp. 618-641.

Sherard, J. L. (1985b). Lessons learned from the Teton dam failure. Proc. Int. Workshop Dam Failures, Purdue University, 6-8 Aug. to be published. Amsterdam: Elsevier.

Sherard, J. L., Dunnigan, L. P., Decker, R. S. \& Steele, E. F. (1976). Pinhole test for identifying dispersive soils. J. Geotech. Engng Div. Am. Soc. Civ. Engrs 102, GT1, 69-85.

Sierra, J. M., Ramirez, C. A. \& Hacelas, J. E. (1985). Design features of Salvajina dam. Proc. Am. Soc. Civ. Engrs Symp. Concrete Face Rockfill Dams, Detroit, pp. 266-285.

da Silveira, A. F. (1984). Statistical analysis of deteriorations and failures of dams. In Safety of dams, pp. 55-60 (ed. Serafim). Rotterdam: Balkema.
Skempton, A. W. (1964). Long-term stability of clay slopes. 4th Rankine Lecture. Géotechnique 14, No. 2, 77-101.

Skempton, A. W. (1985). Residual strength of clays in landslides, folded strata and the laboratory. Géotechnique, 35, No. 1, 3-18.

Skempton, A. W. \& Coats, D. J. (1985). Carsington Dam failure. Failures in earthworks, pp. 203-220. London: Telford.

Smith, N. A. F. (1970). The heritage of Spanish dams. Madrid: Spanish National Committee on Large Dams.

Spangler, M. G. (1933). The supporting strength of rigid pipe culverts. Bulletin 112, Iowa State College of Agriculture and Mechanical Art.

Strange, W. L. (1898). Reservoirs with high earthen dams in western India. Minut. Proc. Instn Cin. Engrs 132, 130-199: Discussion, 200-272.

Taylor, D. W. (1947). Review of pressure distribution theories, earth pressure cell investigations and pressure distribution data. Soil Mechanics Fact Finding Survey-Progress Report, Waterways Experimental Station, Vicksburg.

Thomas, H. S. H. \& Ward, W. H. (1969). The design, construction and performance of a vibrating-wire earth pressure cell. Géotechnique 19, No. 1, 39-51.

Trollope, D. H. (1957). The systematic arching theory applied to the stability analysis of embankments. Proc. 4th Int. Conf. Soil Mech. Fdn Engng, London 2, 382-388.

Uren, F. C (1914). Waterworks engineering. Bristol: Castle Litho.

Vaughan, P. R., Kluth, D. J., Leonard, M. W. \& Pradoura, H. H. M. (1970). Cracking and erosion of the rolled clay core of Balderhead dam and the remedial works adopted for its repair. Trans. 10th Int. Congr. Large Dams, Montreal 1, 73-93.

Vestad, H. (1976). Viddalsvatn dam: a history of leakage and investigations. Trans. 12th Int. Congr. Large Dams, Mexico 2, 369-390.

Walker, F. C. (1948). Experience in the measurement of consolidation and pore pressures in rolled earth dams. Trans. 3rd Int. Congr. Large Dams, Stockholm 2, Q9, R58.

Ward, W. H., Penman, A. \& Gibson, R. E. (1955). Stability of a bank on a thin peat layer. Geotechnique 5 , No. 2, 154-163.

Watakeekul, S., Roberts, G. J. \& Coles, A. J. (1985). Khao Laem-a concrete face rockfill dam on karst. Proc. Am. Soc. Civ. Engrs Symp. Concrete Face Rockfill Dams, Detroit, pp. 336-361.

Waterways Fxperimental Station (1942). Interim report-pressure cell installation-Arkabutla dam. Waterways Experimental Station, Vicksburg.

Westerburg, G., Pira, G. \& Hagrup, J. (1951). Description of some Swedish earth and rockfill dams with concrete core walls and measurement of the movements and pressure in the filling material and the core walls. Trans. 4th Int. Congr. Large Dams, New Delhi, Q13, R11.

Yamauchi, T., Harada, J., Okada, T. \& Shimada, S. (1985). Construction of Tamagawa dam by the RCD method. Trans. 15th Int. Congr. Large Dams, Lausanne 2, 89-115. 


\section{VOTE OF THANKS}

In proposing a vote of thanks to Dr Penman, Professor J. B. Burland made the following remarks.

'I had the privilege and stimulation of working closely with Dr Penman at the Building Research Station for 14 years. The lecture just presented captures much that typifies his unique style and approach as well as exemplifying his life-long love for embankment dams, first kindled by Professor Skempton.

'Arthur Penman is a resourceful researcher and a thoroughly practical engineer. $\mathrm{He}$ is also an enthusiastic sailor. An expedition to a dam site with Arthur, as with a sailing expedition, is an adventure not to be undertaken lightly by the faint hearted. When in harbour with a force seven gale blowing outside Arthur will suggest that we should go out and "just give it a try". Those who have sailed with him will know that once under sail it will take a hurricane to turn him back. Similarly obstacles to instrumenting a dam are there to be overcome and overcome they always are. His enthusiasm is infectious and sweeps all before it and we have experienced that enthusiasm this evening.

'The resourcefulness with which Dr Penman pursues his research is displayed by the immense range of instrumentation he has developed, some of which he has described here. It is in the conception and design of this instrumentation that his skill as a mechanical engineer is displayed and his ideas are widely used all over the world.

'Arthur Penman's devotion to embankment dams is reflected in the many case histories that he has referred to. He has been responsible for the instrumentation in many of them and has developed a deep understanding, almost an intuitive feel, for embankment dam behaviour. The lecture will form a most valuable source of reference for practitioners and students alike.

'I referred to Dr Penman's unique style and I am reminded of a course on research management which he and I attended some years ago. One of the lectures was about communication. The lecturer brought with him an object of complex geometric form. The intention was to choose some unsuspecting soul to describe the object for the class to draw on the basis of the verbal description alone. If the lecturer's intention had been to demonstrate the consequences of poor communication he failed miserably as he happened, quite by chance, to choose Arthur Penman to describc the object. There followed a step by step description of such clarity that everyone on the course drew the object perfectly!

'We have had the benefit of listening to an enthralling, enjoyable and thoroughly stimulating lecture presented with the clarity that we have come to expect from Dr Penman. It is with the very greatest pleasure that I propose a hearty vote of thanks to Dr Penman for a most memorable twenty-sixth Rankine Lecture.' 